Prepared in cooperation with the U.S. Navy

\title{
Mass of Chlorinated Volatile Organic Compounds Removed by Pump-and-Treat, Naval Air Warfare Center, West Trenton, New Jersey, 1996-2010
}
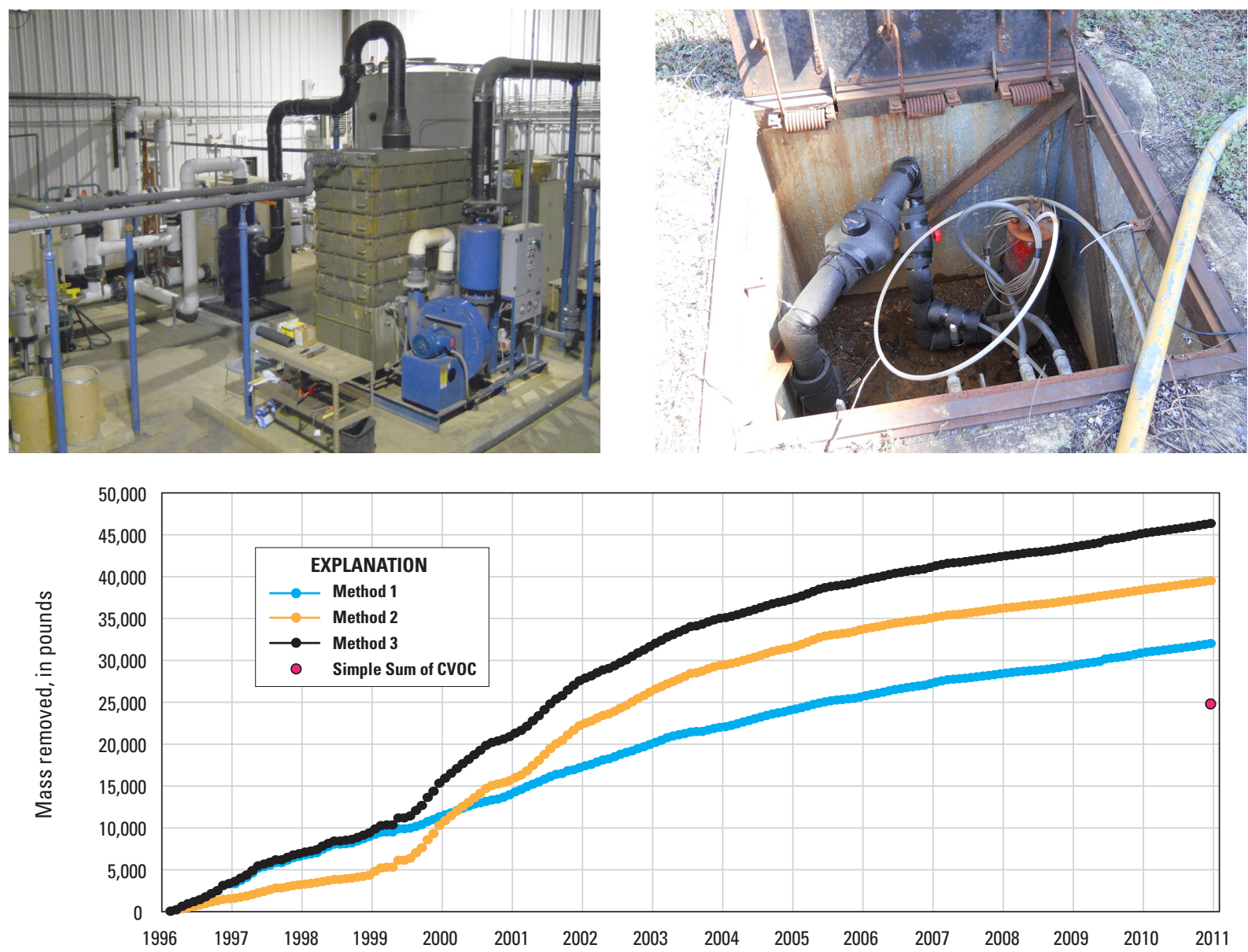

Scientific Investigations Report 2011-5003 


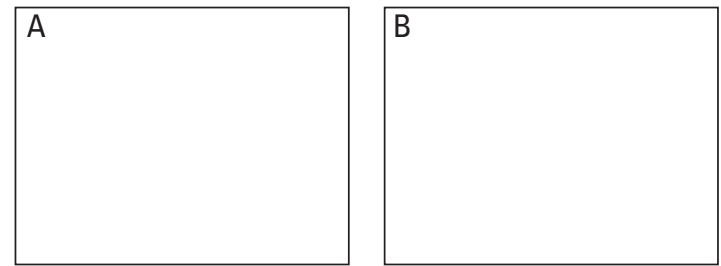

Graph

Cover. Photo A, Pump and Treat plant; Photo B, Pump and Treat recovery well; Graph, shows mass of original trichloroethylene recovered based on analysis of influent to Pump and Treat plant (Method 1), analysis of withdrawal from recovery wells (Method 2), maximum monthly recovery based on Methods 1 and 2, (Method 3) (Photographs by Pierre J. Lacombe, U.S. Geological Survey, March 29, 2011) 


\section{Mass of Chlorinated Volatile Organic Compounds Removed by Pump-and-Treat, Naval Air Warfare Center, West Trenton, New Jersey, 1996-2010}

By Pierre J. Lacombe

Prepared in cooperation with the U.S. Navy

Scientific Investigations Report 2011-5003 


\title{
U.S. Department of the Interior \\ KEN SALAZAR, Secretary \\ U.S. Geological Survey \\ Marcia K. McNutt, Director
}

\author{
U.S. Geological Survey, Reston, Virginia: 2011
}

For more information on the USGS - the Federal source for science about the Earth, its natural and living resources, natural hazards, and the environment, visit http://www.usgs.gov or call 1-888-ASK-USGS

For an overview of USGS information products, including maps, imagery, and publications, visit http://www.usgs.gov/pubprod

To order this and other USGS information products, visit http://store.usgs.gov

Any use of trade, product, or firm names is for descriptive purposes only and does not imply endorsement by the U.S. Government.

Although this report is in the public domain, permission must be secured from the individual copyright owners to reproduce any copyrighted materials contained within this report.

Suggested citation:

Lacombe, P.J., 2011, Mass of chlorinated volatile organic compounds removed by Pump-and-Treat, Naval Air Warfare Center, West Trenton, New Jersey, 1996-2010: U.S. Geological Survey Scientific Investigations Report 2011-5003, 48 p. 


\section{Acknowledgments}

The author thanks Jeff Dale, Robert Lewandowski, and Brian Helland of the U.S. Department of the Navy for providing information on operations of the Pump-and-Treat system. Thanks also go to Thomas Imbrigiotta and Richard Dinacola of the U.S. Geological Survey for providing technical review comments that improved this report. 



\section{Contents}

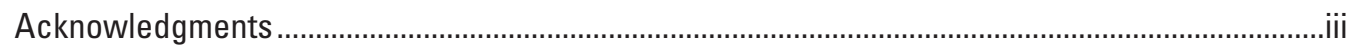

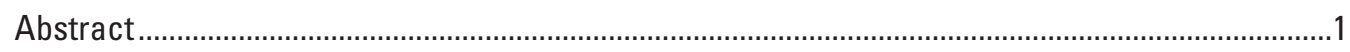

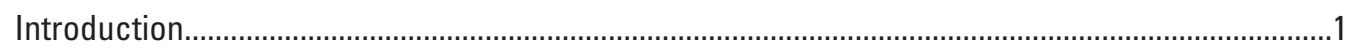

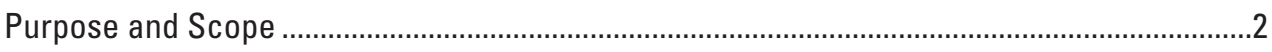

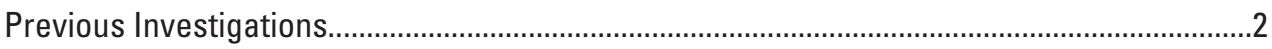

Three Methods of Determining Mass of CVOC Removed ......................................................................4

Results of Method 1: Removal Based on Influent to the Pump and Treat Building ...................5

Mass of TCE, cDCE, and VC Removed.............................................................................

Mass of Original TCE Removed .........................................................................................

Results of Method 2: Removal Based on Withdrawals from the Recovery Wells ..................11

Pumping and Withdrawals Rates for Nine Recovery Wells ............................................11

TCE, cDCE, and VC Concentrations in Water Samples from Nine Recovery Wells........12

Mass of TCE, cDCE, and VC Removed...........................................................................12

Individual Recovery Wells .....................................................................................16

All Recovery Wells............................................................................................ 18

Mass of Original TCE Removed .........................................................................................19

Results of Method 3: Removal Based on Maximum of Methods 1 and 2 ................................27

Discussion of Difference in Masses Based on Methods...................................................................30

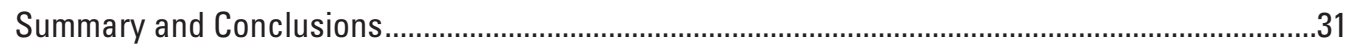

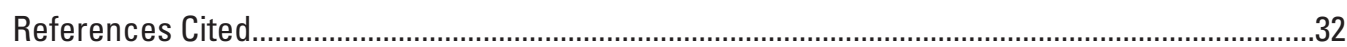




\section{Figures}

1. Map showing locations of pump-and-treat wells, underground pipeline, and building, Naval Air Warfare Center, West Trenton, NJ, 2010...

2. Graphs showing influent volume to the Pump-and-Treat building $(A)$ monthly and $(B)$ cumulatively, Naval Air Warfare Center, West Trenton, NJ, 1996-2010.

3. Graph showing monthly concentrations of trichloroethylene (TCE), cis-dichloroethylene (cDCE), and vinyl chloride (VC) in influent to the Pump and Treat building, Naval Air Warfare Center, West Trenton, NJ, 1996-2010..

4. Graphs showing monthly mass of $(A)$ trichloroethylene (TCE), $(B)$ cis-dichloroethylene (cDCE), and $(C)$ vinyl chloride (VC) removed from influent to the Pump and Treat building, Naval Air Warfare Center, West Trenton, NJ, 1996-2010..

5. Graph showing cumulative mass of trichloroethylene (TCE), cis-dichloroethylene (cDCE), and vinyl chloride (VC) removed from influent to the Pump and Treat building, Naval Air Warfare Center, West Trenton, NJ, 1996-2010

6. Graphs showing amount of trichloroethylene (TCE), cis-dichloroethylene (cDCE), and vinyl chloride (VC) and total chlorinated volatile organic compounds (CVOC) / original TCE removed $(A)$ monthly, $(B)$ cumulatively, and $(C)$ mass in pounds of original TCE removed cumulatively from influent to the Pump and Treat building, Naval Air Warfare Center, West Trenton, NJ, 1996-2010..

7. Graphs showing mass of $(A)$ monthly simple sum of trichloroethylene (TCE), cisdichloroethylene (cDCE), and vinyl chloride (VC) and (B) cumulative simple sum of the above and total chlorinated volatile organic compounds (CVOCs) removed from influent to the Pump and Treat building, Naval Air Warfare Center, West Trenton, NJ, 1996-2010

8. Graphs showing $(A)$ pumping rate, $(B)$ concentrations of trichloroethylene (TCE), cis-dichloroethylene (cDCE), and vinyl chloride (VC) in groundwater samples, $(C)$ monthly mass removed, and $(D)$ cumulative mass removed of TCE, $C D C E$, and VC from recovery well 15BR, Naval Air Warfare Center, West Trenton, NJ, 1996-2010

9. Graphs showing $(A)$ pumpage rate, $(B)$ chlorinated volatile organic compound (CVOC) concentrations in groundwater samples, $(C)$ monthly recovery of CVOC, and $(D)$ cumulative recovery of CVOCs from recovery well 20BR, Naval Air Warfare Center, West Trenton, NJ, 1996-2010.

10. Graphs showing $(A)$ pumpage rate, $(B)$ chlorinated volatile organic compound (CVOC) concentrations in groundwater samples, $(C)$ monthly recovery of CVOC, and $(D)$ cumulative recovery of CVOCs from recovery well 41BR, Naval Air Warfare Center, West Trenton, NJ,1996-2010.

11. Graphs showing $(A)$ pumpage rate, $(B)$ chlorinated volatile organic compound (CVOC) concentrations in groundwater samples, $(C)$ monthly recovery of CVOC, and $(D)$ cumulative recovery of CVOCs from recovery well 41BR, Naval Air Warfare Center, West Trenton, NJ, 1996-2010.

12. Graphs showing $(A)$ pumpage rate, $(B)$ chlorinated volatile organic compound $(\mathrm{CVOC})$ concentrations in groundwater samples, $(C)$ monthly recovery of $\mathrm{CVOC}$, and $(D)$ cumulative recovery of CVOCs from recovery well 41BR, Naval Air Warfare Center, West Trenton, NJ, 1996-2010

13. Graphs showing $(A)$ pumpage rate, $(B)$ chlorinated volatile organic compound (CVOC) concentrations in groundwater samples, $(C)$ monthly recovery of CVOC, and $(D)$ cumulative recovery of CVOCs from recovery well WDW, Naval Air Warfare Center, West Trenton, NJ, 1996-2010

14. Graphs showing $(A)$ pumpage rate, $(B)$ chlorinated volatile organic compound 
(CVOC) concentrations in groundwater samples, $(C)$ monthly recovery of CVOC, and $(D)$ cumulative recovery of CVOCs from recovery well 41BR, Naval Air

Warfare Center, West Trenton, NJ, 1996-2010

15. Graphs showing $(A)$ pumpage rate, $(B)$ chlorinated volatile organic compound (CVOC) concentrations in groundwater samples, $(C)$ monthly recovery of CVOC, and $(D)$ cumulative recovery of CVOCs from recovery well 41BR, Naval Air Warfare Center, West Trenton, NJ, 1996-2010

16. Graphs showing $(A)$ pumpage rate, $(B)$ chlorinated volatile organic compound (CVOC) concentrations in groundwater samples, $(C)$ monthly recovery of CVOC, and $(D)$ cumulative recovery of CVOCs from recovery well 41BR, Naval Air Warfare Center, West Trenton, NJ, 1996-2010

17. Graphs showing mass of $(A)$ trichloroethylene (TCE), $(B)$ cis-dichloroethylene (CDCE), and (C) vinyl chloride (VC) removed from each recovery well, Naval Air Warfare Center, West Trenton, NJ, 1996-2010

18. Graphs showing monthly mass of $(A)$ trichloroethylene (TCE), (B) cis-dichloroethylene (CDCE), and $(C)$ vinyl chloride $(\mathrm{VC})$ removed based on withdrawals from the recovery wells, Naval Air Warfare Center, West Trenton, NJ, 1996-2010

19. Graph showing cumulative mass of trichloroethylene (TCE), cis-dichloroethylene ( $C D C E)$, and vinyl chloride (VC) removed based on withdrawals from the recovery wells, Naval Air Warfare Center, West Trenton, NJ, 1996-2010

20. Graphs showing amount of trichloroethylene (TCE), cis-dichloroethylene (CDCE), and vinyl chloride (VC) and total original TCE removed $(A)$ monthly, $(B)$ cumulatively, and $(C)$ mass of original TCE removed from groundwater by pumping the recovery wells, Naval Air Warfare Center, West Trenton, NJ, 1996-2010.

21. Graphs showing amount of $(A)$ trichloroethylene (TCE), $(B)$ cis-dichloroethylene (cDCE), and (C) vinyl chloride (VC) removed monthly from groundwater using Method 1 from influent to the Pump and Treat building and using Method 2 from groundwater pumped from the recovery wells, Naval Air Warfare Center, West Trenton, NJ, 1996-2010

22. Graphs showing number of pounds of original trichloroethylene (TCE) removed $(A)$ monthly and $(B)$ cumulatively using Method 3, Naval Air Warfare Center, West Trenton, NJ, 1996-2010

23. Graph showing mass removed of original trichloroethylene (TCE) using Methods 1, 2 , and 3 and reported simple sum of the mass of TCE, cis-dichloroethylene (CDCE), and vinyl chloride (VC) removed, Naval Air Warfare Center, West Trenton, NJ, 1996-2010. 


\section{Tables}

1. Reported monthly data and cumulative mass of trichloroethylene (TCE), cis-dichloroethylene (cDCE), vinyl chloride (VC), and original TCE removed based on volume of influent and concentrations of CVOCs in influent to the Pump-and-Treat plant (Method 1), Naval Air Warfare Center, West Trenton, NJ, February 1996 through December 2010.

2. Reported influent to Pump and Treat plant; reported and calculated pumping rates from recovery wells; monthly and cumulative mass of trichloroethylene (TCE), cisdichloroethylene (CDCE), vinyl chloride (VC), and original TCE removal from recovery wells (Method 2), Naval Air Warfare Center, West Trenton, NJ, February 1996 through December 2010 (Separate file at $h$ ttp://pubs.usgs.gov/sir/2011/5003/)

3. Average annual concentrations of chlorinated volatile organic compounds in water samples from recovery wells, for the Pump and Treat plant, Naval Air Warfare Center, West Trenton, NJ, 1996-2010

4. Mass of trichloroethylene (TCE), cis-dichloroethylene (cDCE), and vinyl chloride (VC) recovered by each Pump-and-Treat recovery well, Naval Air Warfare Center, West Trenton, NJ, February 1996-December 2010.

5. Monthly and cumulative number of moles of trichloroethylene (TCE), cis-dichloroethylene (CDCE), vinyl chloride (VC), and original TCE removed determined by using the maximum of Methods 1 and 2, Naval Air Warfare Center, West Trenton, NJ, February 1996 through December 2010.

6. Mass of trichloroethylene (TCE), cis-dichloroethylene (cDCE), vinyl chloride (VC), and original TCE removed by the Pump and Treat system, determined using Methods 1, 2, and 3, Naval Air Warfare Center, West Trenton, NJ, 1996-2010 


\section{Conversion factors}

\begin{tabular}{lcl}
\hline Multiply & By & \multicolumn{1}{c}{ To obtain } \\
\hline meter $(\mathrm{m})$ & Length & \\
kilometer $(\mathrm{km})$ & 3.281 & foot $(\mathrm{ft})$ \\
& 0.6214 & mile $(\mathrm{mi})$ \\
\hline liter $(\mathrm{l})$ & Volume & \\
\hline & 0.2642 & gallon (gal) \\
\hline gram $(\mathrm{g})$ & Mass & pound $(\mathrm{lb})$ \\
\hline & 0.002205 & \\
\hline liter per second $(1 / \mathrm{s})$ & Flow rate & gallon per minute $(\mathrm{gal} / \mathrm{min})$ \\
\hline
\end{tabular}

Chlorinated Volatile Organic Compounds

\begin{tabular}{l|c|c|c}
\hline & $\begin{array}{c}\text { Trichloroethylene } \\
\text { (TCE) }\end{array}$ & $\begin{array}{c}\text { Dichloroethylene } \\
\text { (cDCE and tDCE) }\end{array}$ & $\begin{array}{c}\text { Vinyl chloride } \\
\text { (VC) }\end{array}$ \\
\hline $\begin{array}{l}\text { Molecular weight (grams per mole) } \\
\text { (moles per gram) }\end{array}$ & 131.39 & 96.95 & 62.498 \\
& 0.007611 & 0.010315 & 0.016001 \\
$\begin{array}{l}\text { Density (grams per cubic centimeter) } \\
\text { (cubic centimeter per gram) }\end{array}$ & 1.46 & 1.28 & 0.91 \\
Moles to pounds & 0.684932 & 0.78125 & 1.098901 \\
Pounds to moles & 0.289715 & 0.213775 & 0.13779 \\
& $1.6782 \mathrm{E}-05$ & $7.8507 \mathrm{E}-05$ & $1.2178 \mathrm{E}-04$ \\
Gallons per pound & 0.082 & 0.094 & 0.132 \\
Pound per gallon & 12.183 & 10.681 & 7.594 \\
\hline
\end{tabular}





\title{
Mass of Chlorinated Volatile Organic Compounds Removed by Pump-and-Treat, Naval Air Warfare Center, West Trenton, New Jersey, 1996-2010
}

\author{
By Pierre J. Lacombe
}

\section{Abstract}

Pump and Treat (P\&T) remediation is the primary technique used to contain and remove trichloroethylene (TCE) and its degradation products cis 1-2, dichloroethylene (cDCE) and vinyl chloride (VC) from groundwater at the Naval Air Warfare Center (NAWC), West Trenton, NJ. Three methods were used to determine the masses of TCE, CDCE, and VC removed from groundwater by the P\&T system since it became fully operational in 1996. Method 1, is based on the flow volume and concentrations of TCE, CDCE, and VC in groundwater that entered the P\&T building as influent. Method 2 is based on withdrawal volume from each active recovery well and the concentrations of TCE, cDCE, and VC in the water samples from each well. Method 3 compares the maximum monthly amount of TCE, cDCE, and VC from Method 1 and Method 2. The greater of the two values is selected to represent the masses of TCE, CDCE and VC removed from groundwater each month.

Previously published P\&T monthly reports used Method 1 to determine the mass of TCE, CDCE, and VC removed. The reports state that 8,666 pounds (lbs) of TCE, 13,689 lbs of cDCE, and 2,455 lbs of VC were removed by the P\&T system during 1996-2010. By using Method 2, the mass removed was determined to be $8,985 \mathrm{lbs}$ of TCE, $17,801 \mathrm{lbs}$ of cDCE, and 3,056 lbs of $\mathrm{VC}$ removed, and Method 3, resulted in 10,602 lbs of TCE, 21,029 lbs of cDCE, and 3,496 lbs of $\mathrm{VC}$ removed. To determine the mass of original TCE removed from groundwater, the individual masses of TCE, cDCE, and VC (determined using Methods 1, 2, and 3) were converted to numbers of moles, summed, and converted to pounds of original TCE. By using the molar conversion the mass of original TCE removed from groundwater by Methods 1, 2, and 3 was $32,381 \mathrm{lbs}, 39,535 \mathrm{lbs}$, and 46,452 lbs, respectively, during 1996-2010.

P\&T monthly reports state that $24,805 \mathrm{lbs}$ of summed TCE, cDCE, and VC were removed from groundwater. The simple summing method underestimates the mass of original TCE removed by the P\&T system.

\section{Introduction}

The U.S. Navy installed a pilot Pump-and-Treat (P\&T) system (fig. 1) at the Naval Air Warfare Center (NAWC), West Trenton, NJ, on March 15, 1995. The P\&T containment system was designed to create a cone of depression in the Site 1 and Site 3 Plumes that would (1) prevent flow of chlorinated volatile organic compounds (CVOCs) to the surrounding neighborhood where it might contaminate water-supply wells; and (2) prevent contaminated groundwater from discharging to nearby intermittent streams that flow in the West Ditch culvert and the Gold Run culvert. In addition, the P\&T system was designed to remove trichloroethene (TCE) and its degradation products cis-1,2-dichloroethene (cDCE) and vinyl chloride (VC) from the subsurface.

The pilot P\&T system in 1995 consisted of one recovery well, an underground transmission line, and the P\&T building where the contaminated water was treated. The pilot P\&T system was put into full operation in February 1996. By April 1998 , upgrades to the P\&T system were completed, and the expanded P\&T system consisted of an expanded underground transmission line network and 14 recovery wells that could be pumped at the Navy's discretion. In 1998, wells 04BR, 08BR, 15BR, 16BR, 20BR, 22BR, 29BR, 31BR, 41BR, 45BR, 48BR, BRP-01, BRP-02, and West Ditch well (WDW) were available for use as recovery wells for the P\&T system. In 2004, well 56BR was added to the recovery system. The P\&T system operated continuously during 1996-2010, except for during short periods of maintenance and power outages.

The Navy used TCE as a heat transfer agent while performing tests on jet engines during 1953-95. The Navy had a 25,000-gallon (304,607 pounds (lbs)) capacity TCE piping system with associated valves, pumps, and heat exchanger, as well as three TCE tanks that held a total of 12,825 gallons (156,264 lbs). TCE occasionally would leak from valves, joints, pumps, tanks, and pipes. In addition, TCE was discarded at the NAWC if it was contaminated with water condensation. There is no concise estimate of how much TCE leaked or was discarded at the NAWC. Rogers, Golden, and Halpern, (1986) estimated that during 1951-55 the volume of 
TCE that was disposed of (leaked to waste) was 5,000 gallons $(60,915 \mathrm{lbs})$ and further estimated that during 1951-55 leakage was 10 percent of the waste (leakage) generated after 1955. Rogers, Golden, and Halpern, (RGH; 1986) estimated that 50,000 gallons $(609,150 \mathrm{lbs})$ of TCE leaked during 1955-86. RGH estimated that only 1 percent or 500 gallons $(6,092 \mathrm{lbs})$ of the leakage entered the ground and the rest evaporated. RGH report that tests of three condenser tubes were found to leak refrigerant (TCE) in 1980. RGH also estimated 500 gallons of TCE leaked from a test building at a rate of 20 gallons per year for 25 years. In total, RGH estimated that 55,500 gallons or 676,166 lbs of TCE leaked at NAWC.

On the basis of CVOC concentrations in groundwater, Lacombe (2007) estimated that 2,900 to 47,400 liters $(9,334$ to $152,600 \mathrm{lbs}$ ) of TCE were in the subsurface in 2006. The lesser estimate assumes that the CVOC is in the fracture system only, and the greater estimate assumes that the CVOC is in the fracture system, adsorbed to the rock matrix, and that pure TCE exists in some fractures.

Jet fuel, used during engine tests, also leaked from fuel storage tanks and transmission pipes. The jet fuel tanks and pipes were in the same location as most of the TCE storage tanks and transmission pipes. Because of the fuel spill and the local bedrock geology, much of the TCE in the shallow bedrock biodegraded to various CVOCs and ethane. Analysis of groundwater at NAWC showed that the major CVOCs present are TCE and the major degradation products, $\mathrm{CDCE}$ and VC. Minor CVOCs include trans-1,2-dichloroethene (tDCE), 1,1-dichloroethene, and tetrachloroethene (PCE). Most of the DCE found at the NAWC is cDCE. Only a small mass of tDCE has been removed (49 lbs). In this report, cDCE and tDCE are generally combined and are referred to cumulatively as cDCE.

The first monthly report that documents P\&T operations was published for February 1996. During February 1996 through December 2010, the Navy produced 178 monthly P\&T operation reports to document influent rates, CVOC concentrations, groundwater pumping rates, and monthly and cumulative TCE, cDCE, and VC removals. Reports for 2 months are not available (Sept. 1997 and July 1998.) The study discussed in this report was conducted, in cooperation with the U.S. Navy, to compile and reinterpret the data from the 178 months.

\section{Purpose and Scope}

This report documents the monthly and cumulative mass of TCE, cDCE, and VC, as well as the monthly and total mass of original TCE removed by the P\&T containment system. Original TCE is the compound that leaked from the storage and piping system at the NAWC. Much of the original TCE degraded in the past 45 years to $\mathrm{CDCE}$ and $\mathrm{VC}$. The mass of TCE, cDCE, and $\mathrm{VC}$ removed was determined using three methods. Method 1 uses flow rates and CVOC concentrations of influent entering the P\&T building. Method 2 uses the pumping rates and CVOC concentrations in groundwater from the active recovery wells. Method 3 uses the maximum mass of TCE, CDCE, and VC that was removed monthly and is based on Methods 1 and 2.

Removal of the contaminants documented in this report began in February 1996 and ended in December 2010. Data were obtained from 176 monthly P\&T operations reports for the 178 months and 50 water-quality reports for the groundwater withdrawn by the recovery wells. The reported data are tabulated, graphed, and discussed.

The masses of TCE, CDCE, and VC provided in this report vary from the masses stated in the monthly reports because of errors in adding or publication. The masses of $\mathrm{TCE}, \mathrm{cDCE}$, and VC vary from table to table in this report because of conversion factors and rounding errors.

\section{Previous Investigations}

Foster Wheeler Environmental Corporation (1995) and EA Engineering, Science, and Technology, Inc., (1995) describe start-up of the P\&T operations during 1995. At that time, each component of the P\&T system was tested and evaluated, and by February 1996, the system was operational.

From February 1996 through December 2010, 178 monthly P\&T system reports were prepared by environmental contractors of the U.S. Navy. The first monthly P\&T report was published for February 1996 (Foster Wheeler Environmental Corporation, 1996). Monthly P\&T reports from February 1996 through December 1998 present total volume of P\&T influent and a short description regarding maintenance of, and problems with, operations. Graphs show the concentrations of TCE, cDCE, and VC in influent samples that were collected four to eight times per month. These early P\&T reports do not document the amount of CVOC removed; however, it was possible to calculate the mass of TCE, CDCE, and VC that was removed each month.

From January 1999 through December 2010 (Foster Wheeler Environmental Corporation, 1999-2003; ECOR Solutions, Inc., 2003-10; H\&S Environmental Inc., 2010), monthly P\&T reports contain expanded data and information compared to the 1996-99 P\&T reports. Each report presents the volume of influent, average influent flow rate, hours of operation and downtime, reasons for downtime, and TCE, $\mathrm{cDCE}$, and $\mathrm{VC}$ concentrations in the samples of the influent groundwater. The reports also include instantaneous pumping rates from each active recovery well. In many reports, tDCE concentrations also are included. On the basis of influent flow rates and CVOC concentrations, Foster Wheeler Environmental Corp., ECOR Solutions, Inc., and H\&S Environmental, Inc., documented the monthly and cumulative mass of TCE, cDCE, and VC that was removed by the P\&T system.

During February 1996 to December 1997, well 15BR was the only recovery well in operation. During January to March 1998, wells 15BR and WDW were being used as recovery wells though it is possible that additional wells were being 


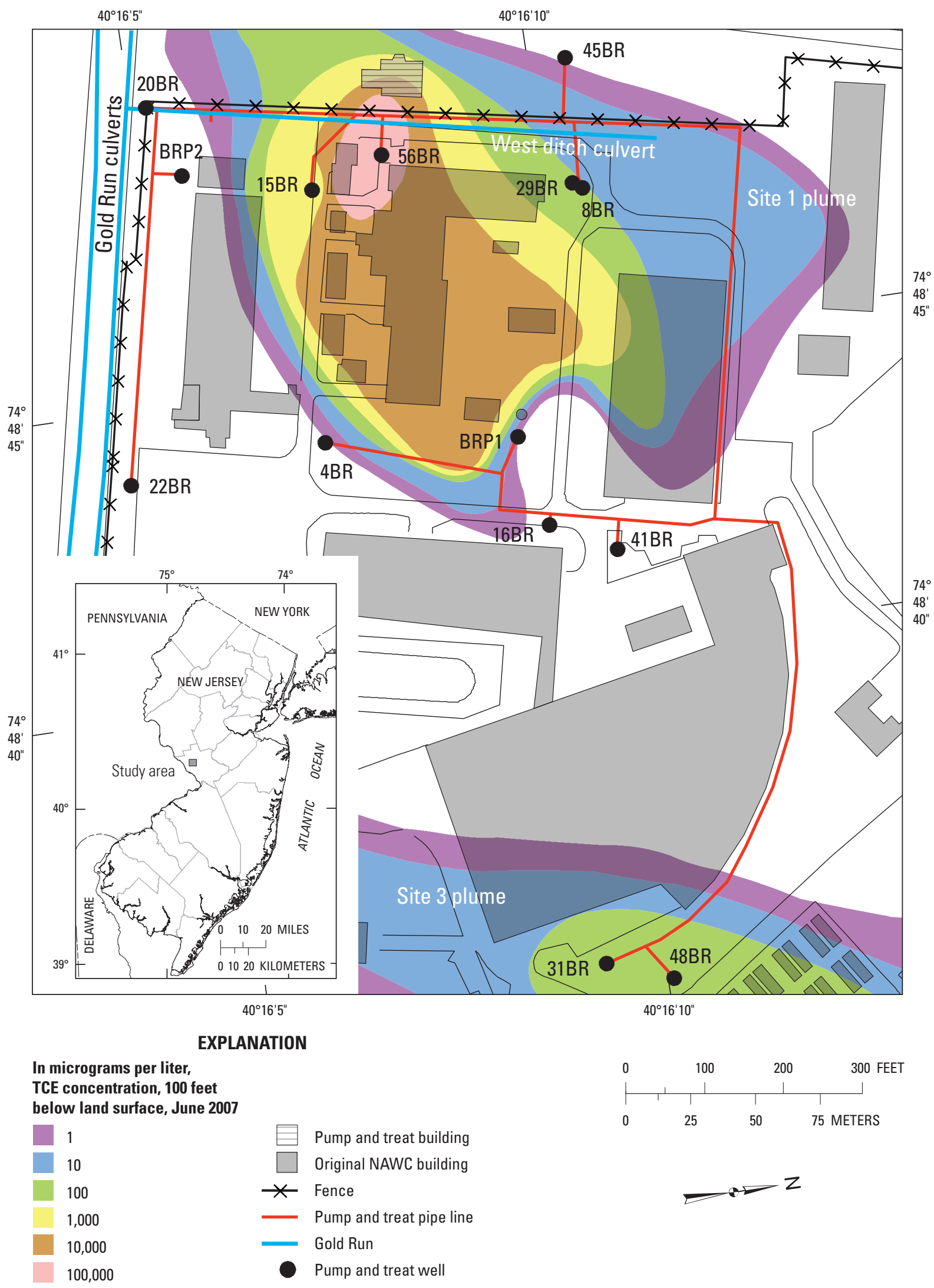

Figure 1. Locations of pump-and-treat wells, underground pipeline, and building, Naval Air Warfare Center, West Trenton, NJ, 2010. 
used for recovery. During April 1998 to December 2000, recovery wells 15BR, 20BR, 41BR, 45BR, 48BR, and WDW were used. Pumping rates from these recovery wells during 1998 are shown in this report to be equal. In all likelihood, withdrawals were not equal. Pumping rates were likely similar to those published in later reports. Pumping rates in these recovery wells during 1999 to 2000 are the reported recovery rates. In January 2001 , the $P \& T$ system was reconfigured to pump from seven wells-15BR, 20BR, 22BR, 45BR, 48BR, WDW, and BRP-02. In July 2004, recovery well 56BR was added to the P\&T system. During September to December 1999, well 36BR was pumped as part of a second pilot test to evaluate an experimental nano-scale iron filing remediation method. Only a few hundred gallons of water were withdrawn during this test.

Monthly P\&T reports from 1999 through 2010 include the average monthly influent flow rates that were calculated by using two methods. The most commonly used method consisted of dividing the monthly influent flow rate by the number of minutes in the month that the P\&T system was operating properly. The second and less frequently used method consisted of dividing the monthly influent flow rate by the number of minutes in the month. Five laboratories were used consecutively to analyze the P\&T influent water samples for TCE, cDCE, and VC.

Fifty quarterly and annual reports showing concentrations of TCE, cDCE, and VC in groundwater samples from recovery wells were published by EA Engineering, Science, and Technology, Inc., during 1997 to mid 2003; by ECOR Solutions, Inc., during mid 2003 to early 2010; and by H\&S Environmental, Inc., during early to late 2010. There were four groundwater quality reports for most years. However, there is no groundwater quality report for 1996, one report in 1997 and 2002, and two reports in 1998 and 2003. The reports show that seven laboratories were used consecutively to analyze the groundwater samples for TCE, cDCE, and VC. During 1999 and 2004, each laboratory was used for 1 year or less.

\section{Three Methods of Determining Mass of CVOC Removed}

Three methods were used in this study to determine the monthly masses of TCE, cDCE, VC, and original TCE that were removed by the $\mathrm{P} \& \mathrm{~T}$ system. Method 1 calculations are based on monthly flow rate measurements and monthly CVOC concentration measurements of groundwater influent to the P\&T building. Method 2 calculations are based on monthly pumping rates and average annual CVOC concentration measurements made on groundwater from each recovery well. Method 3 calculations are based on the greater of the two values determined by Methods 1 and 2 for each month. Because of independent rounding, sums are not equal in some instances.
Method 1 was used to calculate the mass of TCE, cDCE, and $\mathrm{VC}$ that was removed from P\&T influent each month; it is based on (1) the monthly influent volume to the P\&T building and (2) average monthly concentrations of TCE, cDCE, and $\mathrm{VC}$ in influent to the building.

The mass of TCE, cDCE, and VC removed was calculated using

$$
{ }^{i} M_{w}=\left(V_{i n f}\right)\left({ }^{i} C\right) k
$$

where

$$
\begin{array}{cl}
{ }^{i} M_{w} & \text { is mass of individual CVOC, in pounds; } \\
V_{\text {inf }} & \text { is monthly volume of influent, in gallons; } \\
{ }^{i} C & \text { is concentration of each CVOC in influent, } \\
& \text { in micrograms per liter; and } \\
k & \text { is a constant to balance units. }
\end{array}
$$

The mass of original TCE removed each month was also calculated using Method 1.

The monthly mass was calculated by converting the mass of each CVOC compound to a number of moles of each compound. The number of moles were summed and converted to the mass of original TCE.

$$
{ }^{\text {Total }} m M=\left({ }^{T} M_{w}\right)\left({ }^{T} m k\right)+\left({ }^{D} M_{w}\right)\left({ }^{D} m k\right)+\left({ }^{V} M_{w}\right)\left({ }^{V} m k\right),
$$

where

$$
\begin{aligned}
{ }^{\text {Total }} m M & \text { is the sum of the number of moles and } \\
{ }^{i} m k & \text { is a constant to convert mass in pounds to } \\
& \text { number of moles of individual CVOC. }
\end{aligned}
$$

The Navy used Method 1 to calculate the masses of TCE, CDCE, and VC removed each month, then summed the masses of TCE, cDCE, and VC that were removed each month to determine the total CVOCs removed. This summation does not adequately reflect the mass of original TCE that was removed.

Method 2 was used to calculate the masses of TCE, CDCE, and VC that were removed each month on the basis of (1) the monthly withdrawals from each recovery well and (2) the average annual concentrations of TCE, CDCE, and VC in water samples from each recovery well.

Monthly discharge from a well was calculated using

$$
V_{i w}=\left(Q_{i} / \sum Q\right)\left(V_{i n f}\right) \text {, }
$$

where

$$
\begin{aligned}
& V_{i w} \quad \text { is the monthly volume of withdrawal from an } \\
& \text { individual recovery well, in gallons; } \\
& Q_{i} \quad \text { is the instantaneous rate of withdrawal } \\
& \text { reported for an individual recovery well, in } \\
& \text { gallons; and } \\
& Q \quad \text { is the instantaneous rate of withdrawal } \\
& \text { reported for all recovery wells, in gallons. }
\end{aligned}
$$


The masses of TCE, cDCE, and VC removed from each recovery well were calculated using

$$
{ }^{i} M_{w}=\left(V_{i w}\right)\left({ }^{w} C\right) k,
$$

where

$$
\begin{aligned}
& { }^{w} C \quad \text { is the average annual concentration of TCE, } \\
& \text { cDCE, and VC for water samples from a } \\
& \text { recovery well. }
\end{aligned}
$$

The mass of original TCE removed by Method 2 was calculated as described in Method 1.

The simple sum of the masses of TCE, cDCE, and VC that were removed as calculated by Method 2 is included in this report. The simple summation is included for comparison with the simple sum method that was used in Method 1.

Method 3 was used to calculate the masses of TCE, cDCE, and VC that were removed each month, based on the greater mass of Methods 1 or Method 2. The value determined using Method 1 was compared to the value from Method 2, and the greater of the two values was selected. This was done for each month during 1996-2010.

Method 1, in general, produced greater mass removal for 1996 to 1998, and Method 2, in general, produced greater mass removal for 2000 to 2004 . The mass removed monthly during 2005 to 2010 using the two methods was similar.

\section{Results of Method 1: Removal Based on Influent to the Pump and Treat Building}

The results of Method 1 are that the P\&T building has received 280,088,872 gallons of influent during 1996-2010 and removed 8,666 lbs of TCE, 13,689 lbs of cDCE, and $2,456 \mathrm{lbs}$ of VC. The mass of original TCE removed as calculated by Method 1 is 32,381 lbs.

\section{Mass of TCE, cDCE, and VC Removed}

Monthly influent volume to the P\&T building (fig. 2A; table 1 , at end of report) was about 500,000 gal during 1996-97. Recovery well 15BR was the only well pumped during this time. Influent flow rate increased to about 1,500,000 gal/mon during 1998-99 after the Navy increased the number of recovery wells to six. During 2000-09, the P\&T system generally pumped eight recovery wells, and influent flow rates fluctuated from 750,000 to $2,500,000 \mathrm{gal} / \mathrm{mon}$. Average influent flow rate was about $1,815,000 \mathrm{gal} / \mathrm{mon}$ during 2000-10. The cumulative volume of influent to the $\mathrm{P} \& \mathrm{~T}$ building during 1996-2010 was $280,088,872$ gal (fig. 2B). The volume accumulated at a relatively constant rate during 1996-99, and increased by a factor of 4 during 2000-10.

Reported average monthly concentrations of TCE, cDCE, and $\mathrm{VC}$ in the influent to the P\&T building are shown in figure 3 and table 1. During 1996-98, concentrations of the CVOCs are presented only on graphs in the monthly reports and were extrapolated for this report. During 1999-2004, three to five concentrations of each CVOC were given in each monthly report and the average monthly concentration for each CVOC typically was used for this report. However, for some months, the CVOC concentrations that are presented in this report are the values that were used in the monthly P\&T reports to calculate the masses removed of TCE, cDCE, and VC. During 2005-09, only one concentration of each CVOC was reported monthly, and that concentration is included in this report (table 1).

Monthly concentrations of TCE in the influent ranged from about 2,000 to about $25,000 \mu \mathrm{g} / \mathrm{L}$ during $1996-98$ (fig. 3). After 1999, average monthly concentrations of TCE rarely exceeded 5,000 $\mu \mathrm{g} / \mathrm{L}$, and generally declined from about 5,000 to $2,000 \mu \mathrm{g} / \mathrm{L}$. Monthly concentrations of cDCE in the influent ranged from 10,000 to $62,000 \mu \mathrm{g} / \mathrm{L}$ during 1996-98. After 1999, average monthly concentrations of cDCE rarely exceeded $10,000 \mu \mathrm{g} / \mathrm{L}$. Monthly concentrations of cDCE steadily declined from about 10,000 to about $2,500 \mu \mathrm{g} / \mathrm{L}$ during 2000-10. Monthly concentrations of VC in the influent ranged from 2,000 to $10,000 \mu \mathrm{g} / \mathrm{L}$ during $1996-98$. After 1998 , monthly concentrations rarely exceeded $2,000 \mu \mathrm{g} / \mathrm{L}$. Monthly concentrations of $\mathrm{VC}$ declined from about 1,500 to less than $60 \mu \mathrm{g} / \mathrm{L}$ during 2000-10.

The mass of TCE removed each month, based on measurements of influent to the P\&T building, ranged from 3.6 to $151 \mathrm{lbs}$ with a mean of $49 \mathrm{lbs}$ (fig. 4A; table 1). The general trend in the monthly mass of TCE removed was a slight decrease from a range of 60 to 80 pounds per month (lbs/mon) during 1996-2001 to a range of 30 to $40 \mathrm{lbs} / \mathrm{mon}$ during 2007-09.

The mass of cDCE removed each month ranged from 5.6 to $309 \mathrm{lbs}$ with a mean of $77 \mathrm{lbs}$ (fig. 4B; table 1). Monthly mass removal of cDCE steadily decreased from about $150 \mathrm{lbs} / \mathrm{mon}$ in the late 1990s to less than $50 \mathrm{lbs} / \mathrm{mon}$ in 2010. The mass of $\mathrm{VC}$ removed each month ranged from 0.5 to $46 \mathrm{lbs}$ with a mean of $14 \mathrm{lbs}$ (fig. 4C). Monthly mass removal of VC decreased step wise from about $25 \mathrm{lbs} / \mathrm{mon}$ during 1996-2003 to less than $5 \mathrm{lbs} / \mathrm{mon}$ during 2003-09. The maximum cumulative mass of each CVOC that had been removed (fig. 5) during 1996-2010 for TCE was 8,666 lbs, for cDCE was $13,689 \mathrm{lbs}$, and for $\mathrm{VC}$ was $2,456 \mathrm{lbs}$.

\section{Mass of Original TCE Removed}

The mass of original TCE removed each month was calculated by converting the mass of TCE, cDCE, and VC from pounds to the number of moles (fig. 6A, table 1). The numbers of moles were summed (fig. 6A) to show the monthly and cumulative number of moles removed from influent to the P\&T building (fig. 6B). The cumulative number of moles removed was converted to a mass of original TCE (fig. 6C) to show the mass of original TCE that was removed.

The monthly number of moles of TCE removed ranged from 12 to 520 with a mean of 166 . The monthly number of moles of cDCE removed ranged from 26 to 1,445 with a mean 


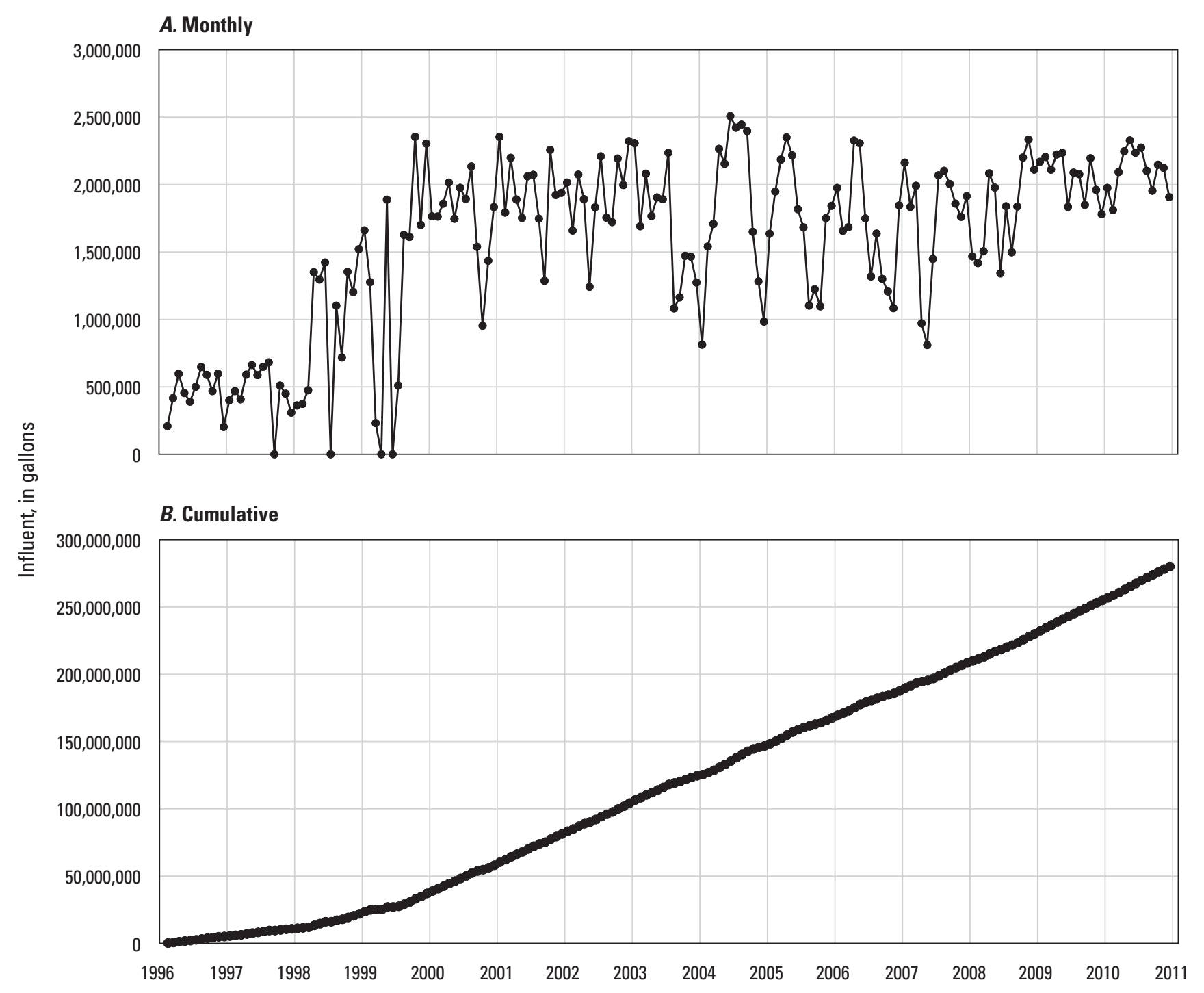

Figure 2. Influent volume to the Pump-and-Treat building $(A)$ monthly and $(B)$ cumulatively, Naval Air Warfare Center, West Trenton, NJ, 1996-2010.

of 358. The monthly number of moles of VC removed ranged from 7 to 337 with a mean of 99 . The total monthly number of moles of original TCE removed ranged from 60 to 2,165 with an average of 618 .

The cumulative number of moles removed during the period of operation for TCE is 29,911; for cDCE, 64,033; and for $\mathrm{VC}, 17,823$. The cumulative number of moles of the origi- nal TCE removed is 111,767 . The cumulative mass of original TCE removed from influent to the P\&T building is $32,375 \mathrm{lbs}$.

The Navy summed the masses of TCE, cDCE, and VC to report the total mass of CVOCs removed each month, as well as the cumulative mass of CVOC removed (fig. 7). As stated previously, the results of this summing are included for illustration purposes. The summed total cumulative mass of CVOC removed is $24,806 \mathrm{lbs}$. 


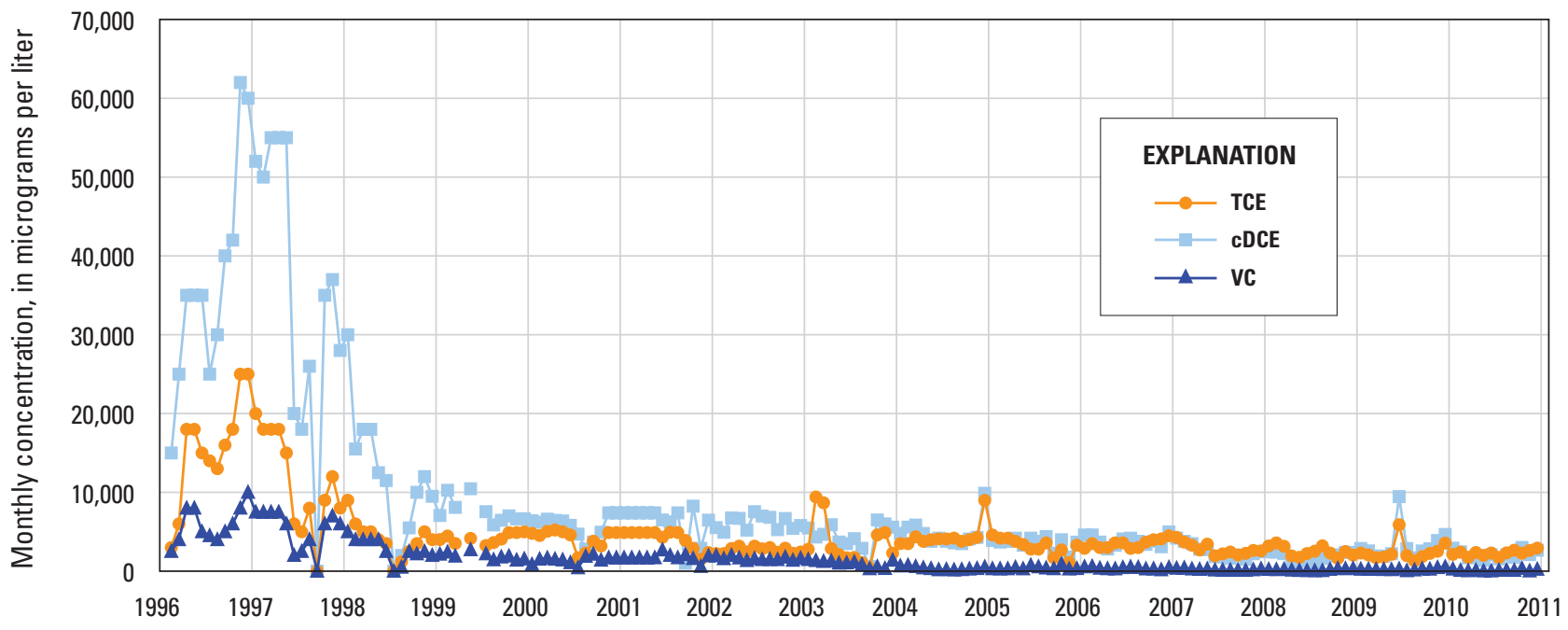

Figure 3. Monthly concentrations of trichloroethylene (TCE), cis-dichloroethylene (CDCE), and vinyl chloride (VC) in influent to the Pump and Treat building, Naval Air Warfare Center, West Trenton, NJ, 1996-2010. 

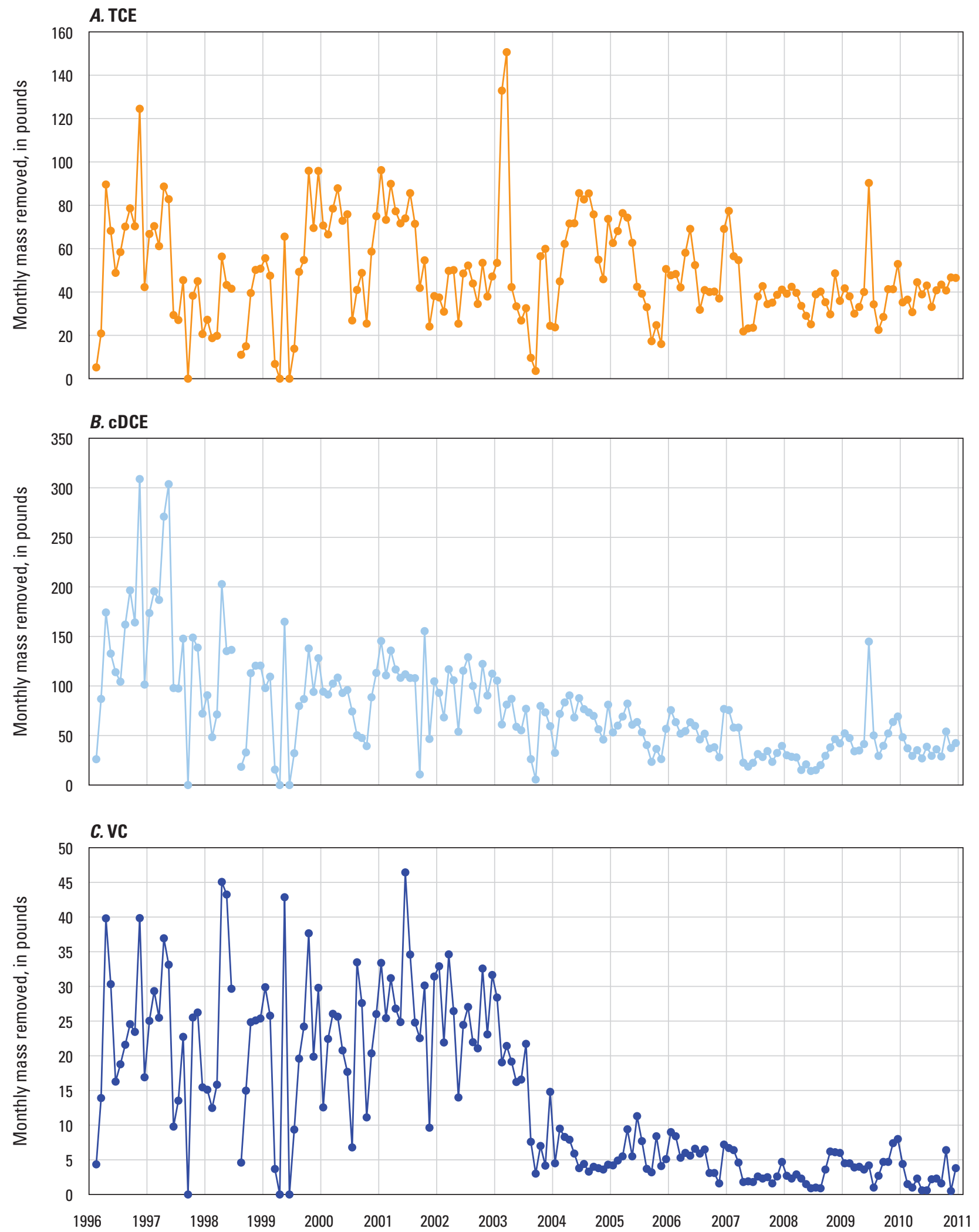

Figure 4. Monthly mass of $(A)$ trichloroethylene (TCE), $(B)$ cis-dichloroethylene (cDCE), and $(C)$ vinyl chloride (VC) removed from influent to the Pump and Treat building, Naval Air Warfare Center, West Trenton, NJ, 1996-2010. 


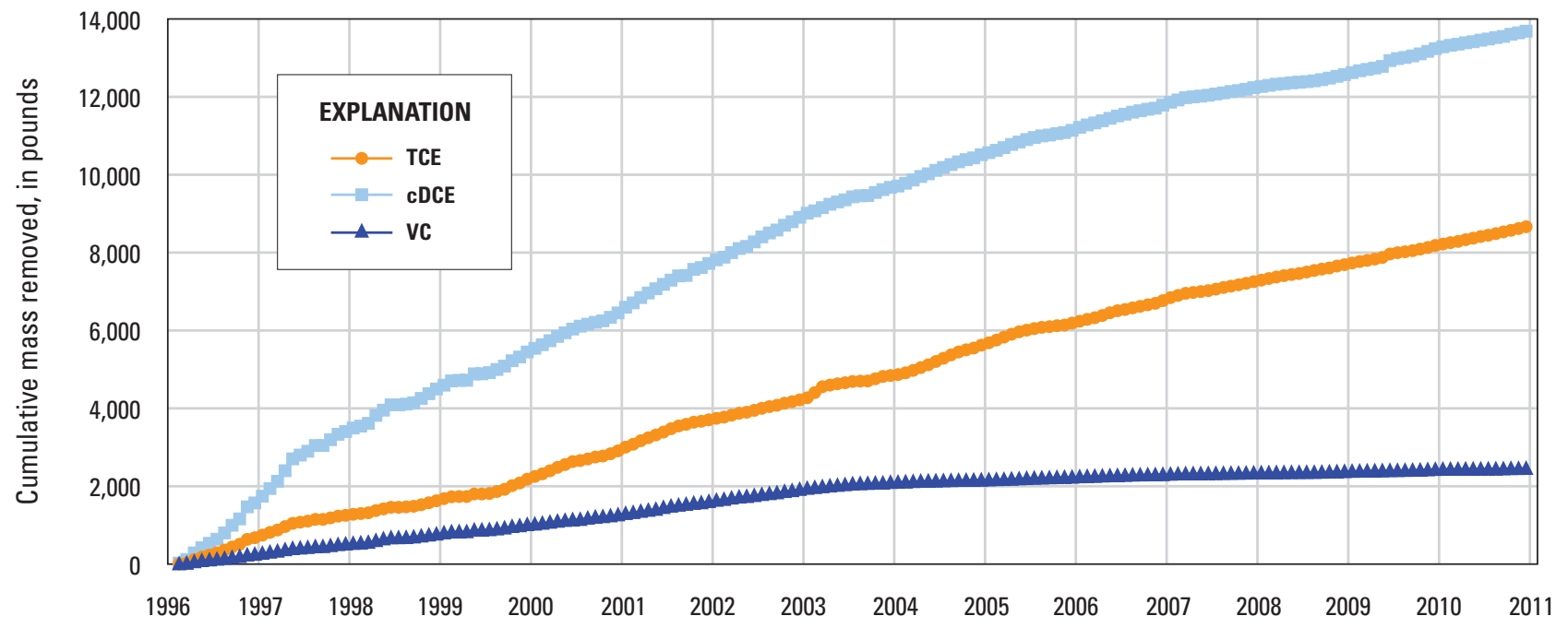

Figure 5. Cumulative mass of trichloroethylene (TCE), cis-dichloroethylene (CDCE), and vinyl chloride (VC) removed from influent to the Pump and Treat building, Naval Air Warfare Center, West Trenton, NJ, 1996-2010. 

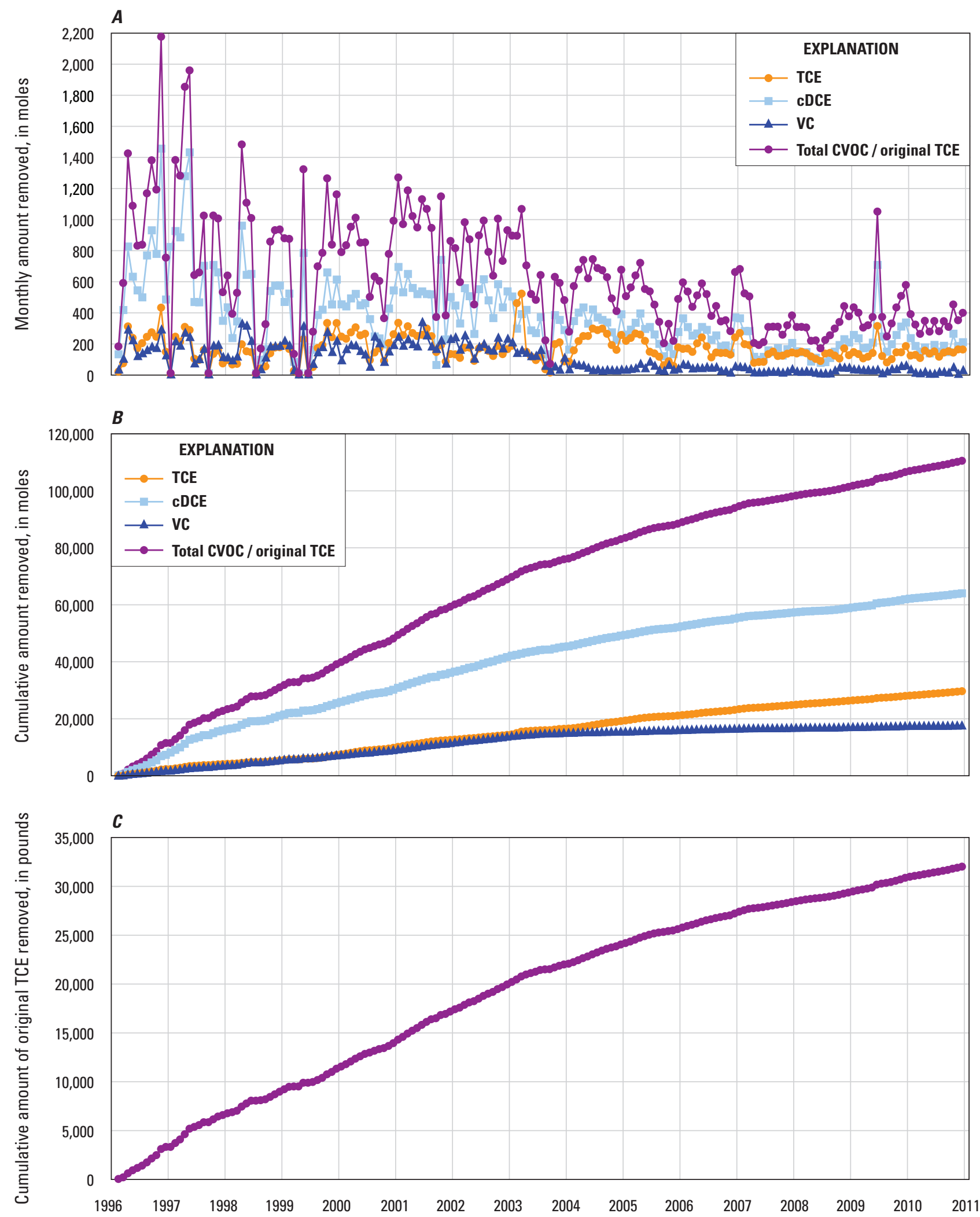

Figure 6. Amount of trichloroethylene (TCE), cis-dichloroethylene (CDCE), and vinyl chloride (VC) and total chlorinated volatile organic compounds (CVOC) / original TCE removed $(A)$ monthly, $(B)$ cumulatively, and $(C)$ mass in pounds of original TCE removed cumulatively from influent to the Pump and Treat building, Naval Air Warfare Center, West Trenton, NJ, 1996-2010. 

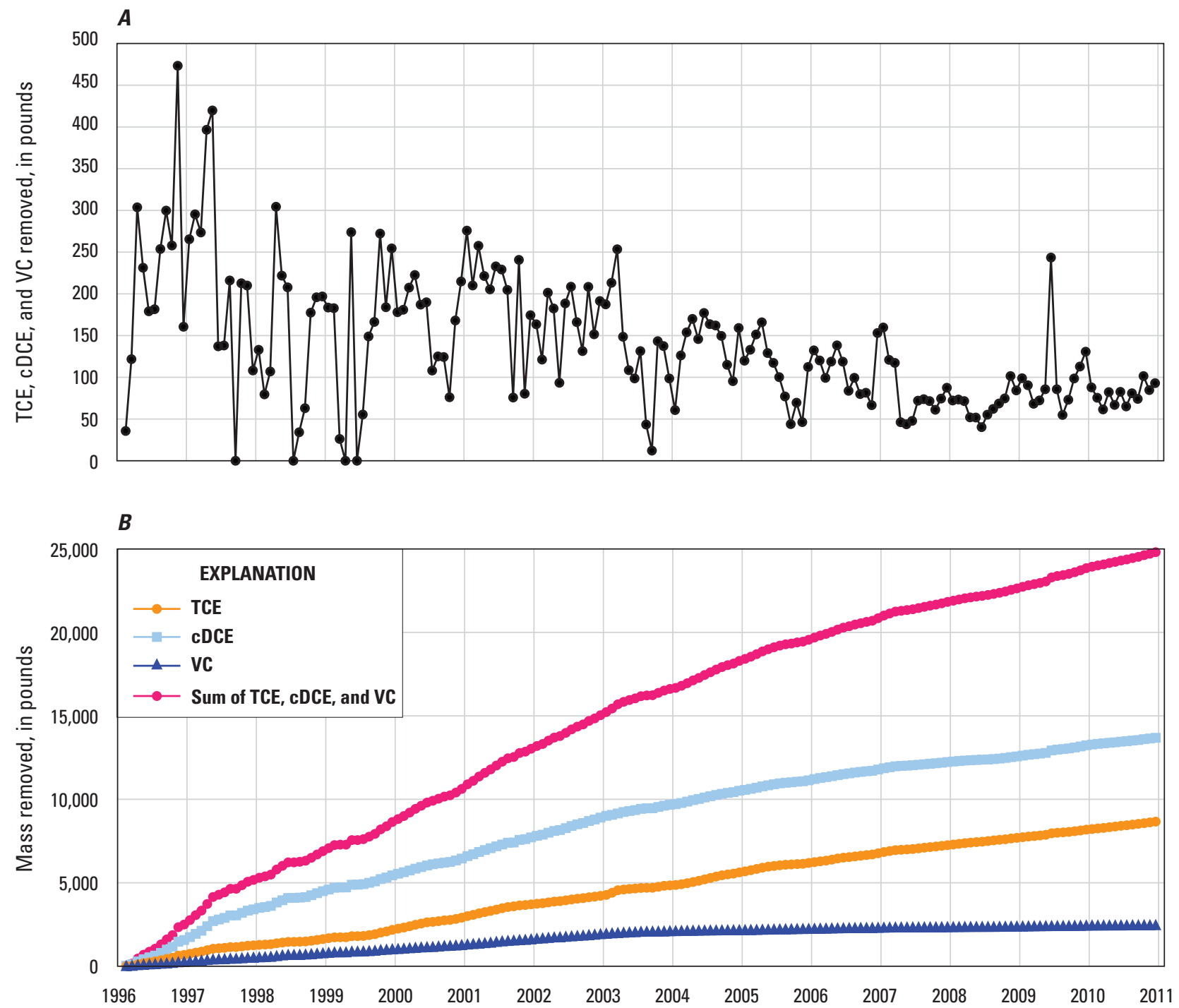

Figure 7. Mass of $(A)$ monthly simple sum of trichloroethylene (TCE), cis-dichloroethylene (CDCE), and vinyl chloride (VC) and (B) cumulative simple sum of the above and total chlorinated volatile organic compounds (CVOCs) removed from influent to the Pump and Treat building, Naval Air Warfare Center, West Trenton, NJ, 1996-2010.

\section{Results of Method 2: Removal Based on Withdrawals from the Recovery Wells}

Eleven recovery wells were used to withdraw contaminated groundwater for the P\&T system (15BR, 20BR, 41BR, 45BR, 48BR, WDW, BRP-02, 22BR, 56BR, 8BR, and 29BR). Well 15BR was used for containment and recovery of contaminated water for 14 years (1996 through 2010). The other recovery wells were used for less than 1 to 12 years (table 2, separate file at $h t t p: / / p u b s . u s g s . g o v /$ sir/2011/5003/). The masses of TCE, cDCE, and VC that were removed each month from each recovery well were calculated by using (1) the volume of water withdrawn from each well, based on the reported instantaneous pumping rate, influent flow rate to the $\mathrm{P} \& \mathrm{~T}$ building, and time of operation of the P\&T system and (2) the concentrations of TCE, cDCE, and VC in water samples from each recovery well.

\section{Pumping and Withdrawals Rates for Nine Recovery Wells}

The monthly instantaneous pumping rates for each of eleven recovery wells (figs. $8 \mathrm{~A}$ to $16 \mathrm{~A}$; table 2 ) were obtained from data presented in the monthly P\&T operations reports. The sum of the monthly instantaneous pumping rates of the operating recovery wells rarely equaled the monthly flow rate 

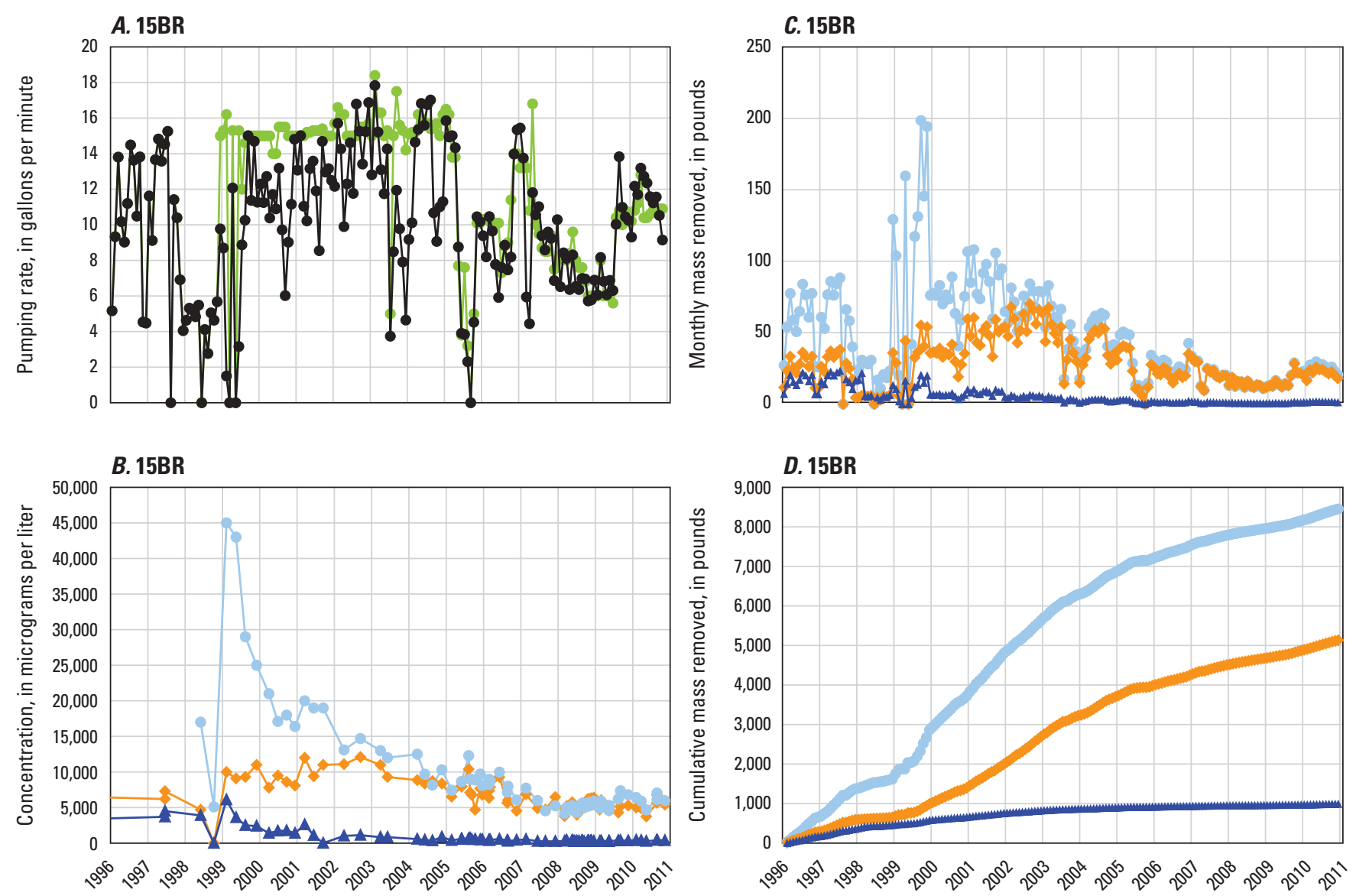

\section{EXPLANATION}

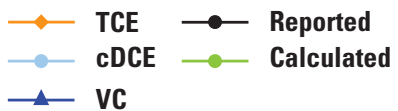

Figure 8. ( $A$ ) Pumping rate, $(B)$ concentrations of trichloroethylene (TCE), cis-dichloroethylene (CDCE), and vinyl chloride (VC) in groundwater samples, $(C)$ monthly mass removed, and $(D)$ cumulative mass removed of TCE, CDCE, and VC from recovery well 15BR, Naval Air Warfare Center, West Trenton, NJ, 1996-2010.

that was reported for the influent into the P\&T building. The monthly average pumping rate for each recovery well was calculated by prorating the monthly instantaneous flow rate for each well on the basis of the monthly flow rate of influent to the P\&T building (fig. 8A to 16A). The volume of water that was removed each month from each well was calculated on the basis of the monthly average pumping rate and the length of time that the P\&T system was operating that month. (table 2).

\section{TCE, cDCE, and VC Concentrations in Water Samples from Nine Recovery Wells}

The concentrations of TCE, cDCE, and VC in water samples from nine recovery wells (fig. 8B to 16B; table 3 ) are from quarterly and annual water-quality reports. The average annual concentrations of TCE, CDCE, and VC were used to calculate the amount of each CVOC removed from each recovery well. TCE, cDCE, and VC concentrations in water samples decreased in most recovery wells during 1998-2010. The decrease in concentration is a result of CVOC removal by the P\&T system, monitored natural attenuation, enhanced biodegradation, thermal conductive heating, and removal of contaminated soil.

\section{Mass of TCE, CDCE, and VC Removed}

The masses of TCE, cDCE, and VC removed each month by pumping each recovery wells were calculated, based on the volume of water pumped each month and the average annual 







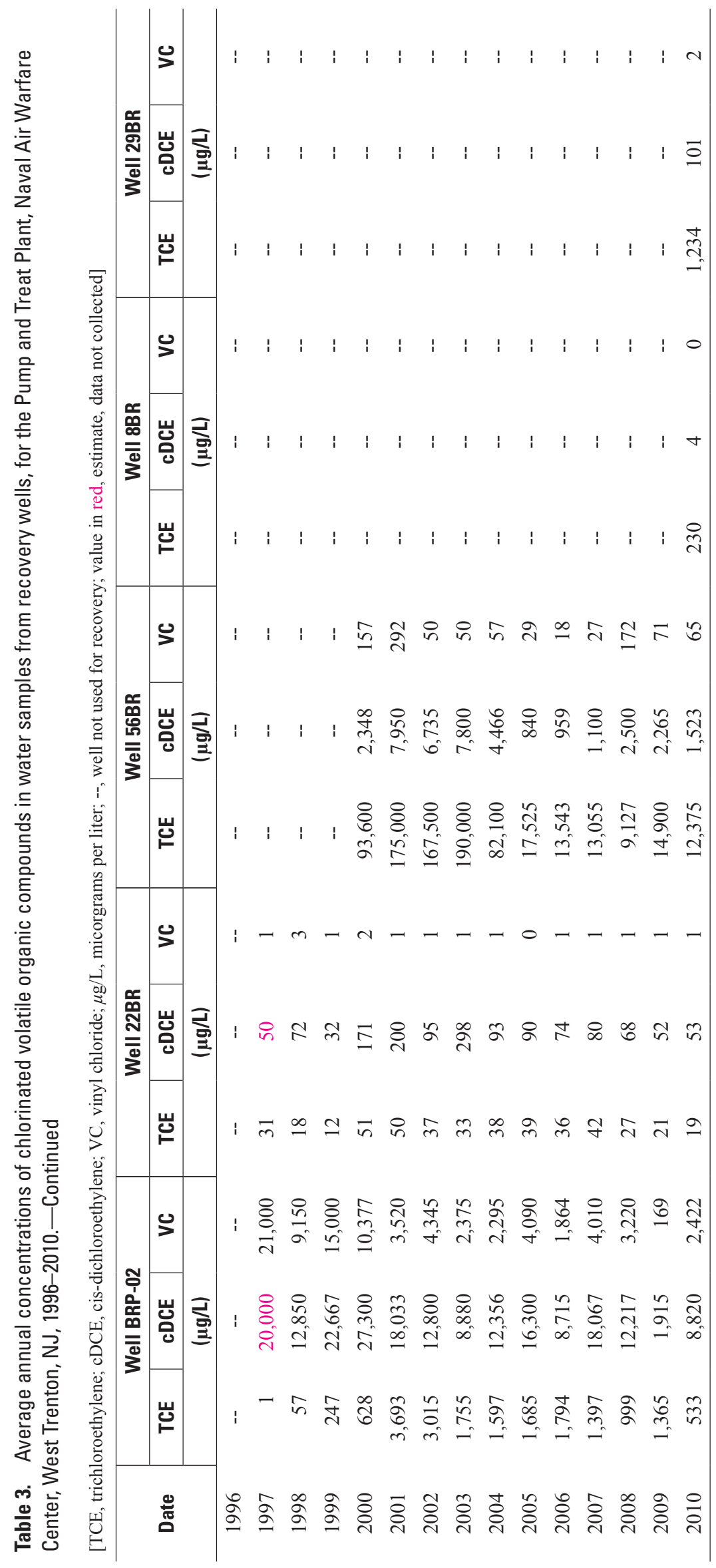


Table 4. Mass of trichloroethylene (TCE), cis-dichloroethylene (CDCE), and vinyl chloride (VC) recovered by each Pump-and-Treat recovery well, Naval Air Warfare Center, West Trenton, NJ, February 1996-December 2010.

\begin{tabular}{l|r|r|r|r|r|r|r|r|r|r|r|r}
\hline & 15BR & 20BR & 41BR & 45BR & 48BR & WDW & BRP2 & 22BR & 56BR & 8BR & 29BR & Total \\
\hline \multicolumn{10}{c}{ In pounds } \\
\hline TCE & 5,133 & 1,063 & 37 & 1,059 & 450 & 138 & 231 & 8 & 848 & 3 & 12 & 8,983 \\
CDCE & 8,452 & 7,587 & 35 & 129 & 20 & 85 & 1,422 & 24 & 43 & 0 & 1 & 17,798 \\
VC & 997 & 1,693 & 2 & 1 & 2 & 22 & 338 & 0 & 2 & 0 & 0 & 3,056 \\
\hline
\end{tabular}

A. 20BR

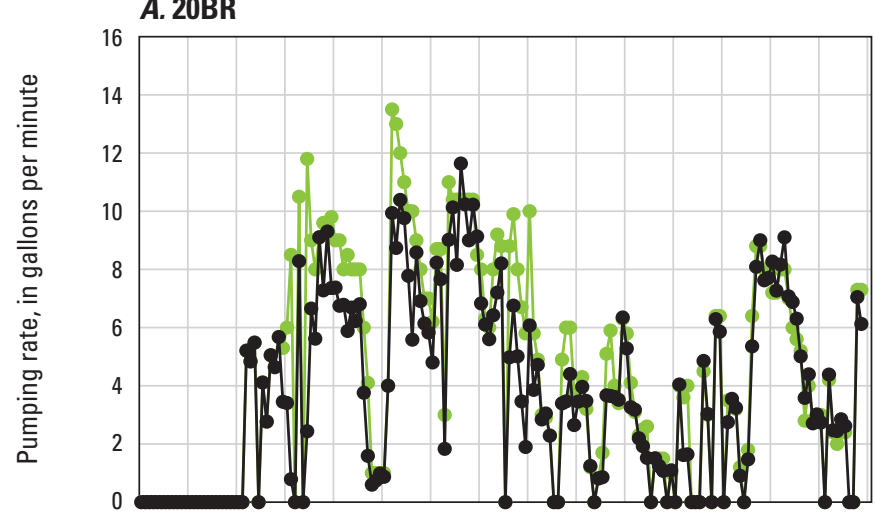

B. 20BR

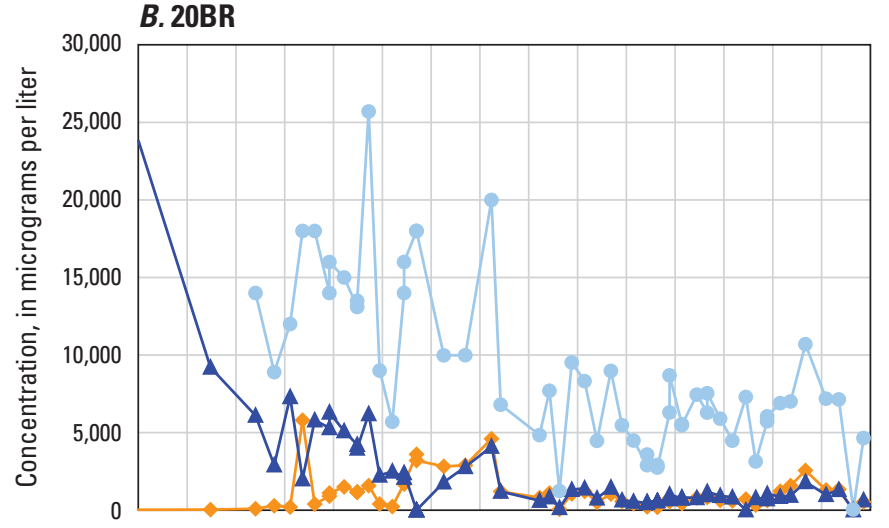

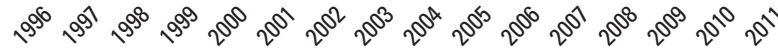

C. 20BR
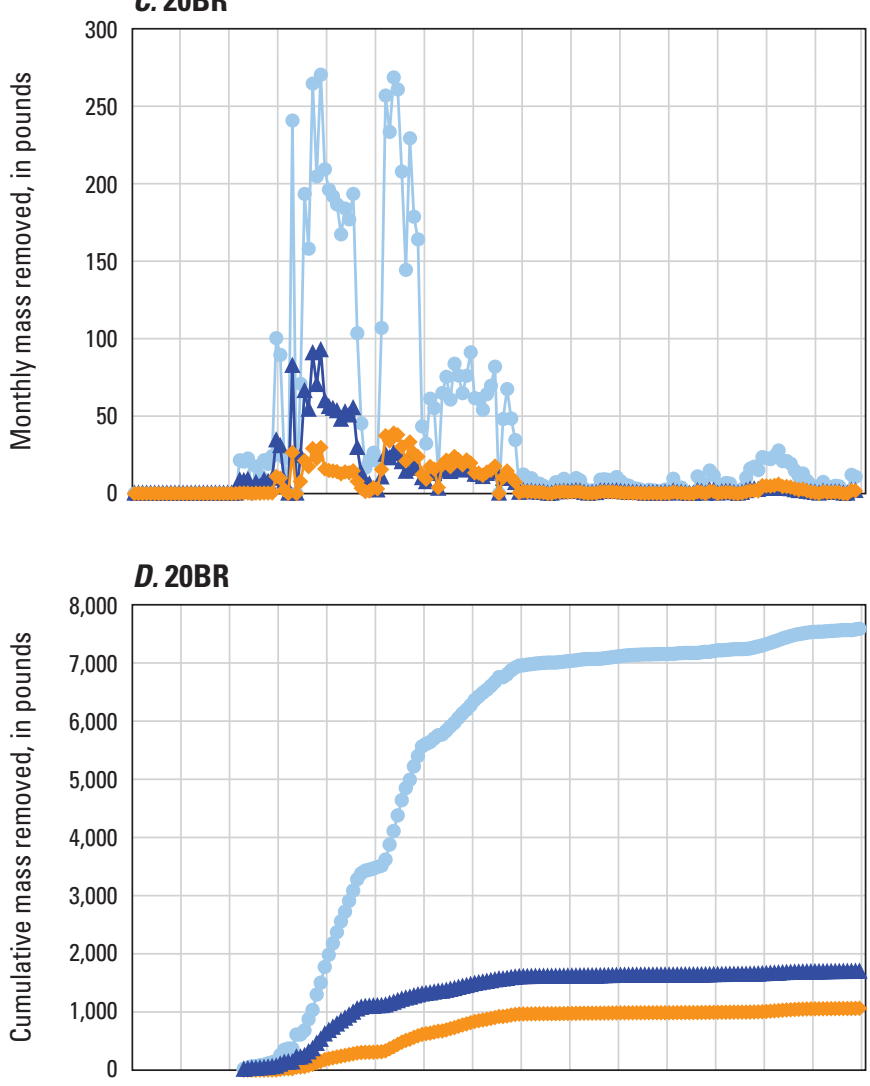

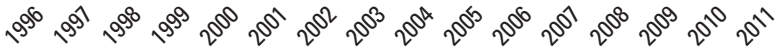

\section{EXPLANATION}

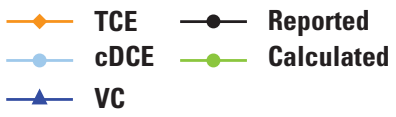

Figure 9. (A) Pumpage rate, $(B)$ chlorinated volatile organic compound (CVOC) concentrations in groundwater samples, $(C)$ monthly recovery of CVOC, and $(D)$ cumulative recovery of CVOCs from recovery well 20BR, Naval Air Warfare Center, West Trenton, NJ, 

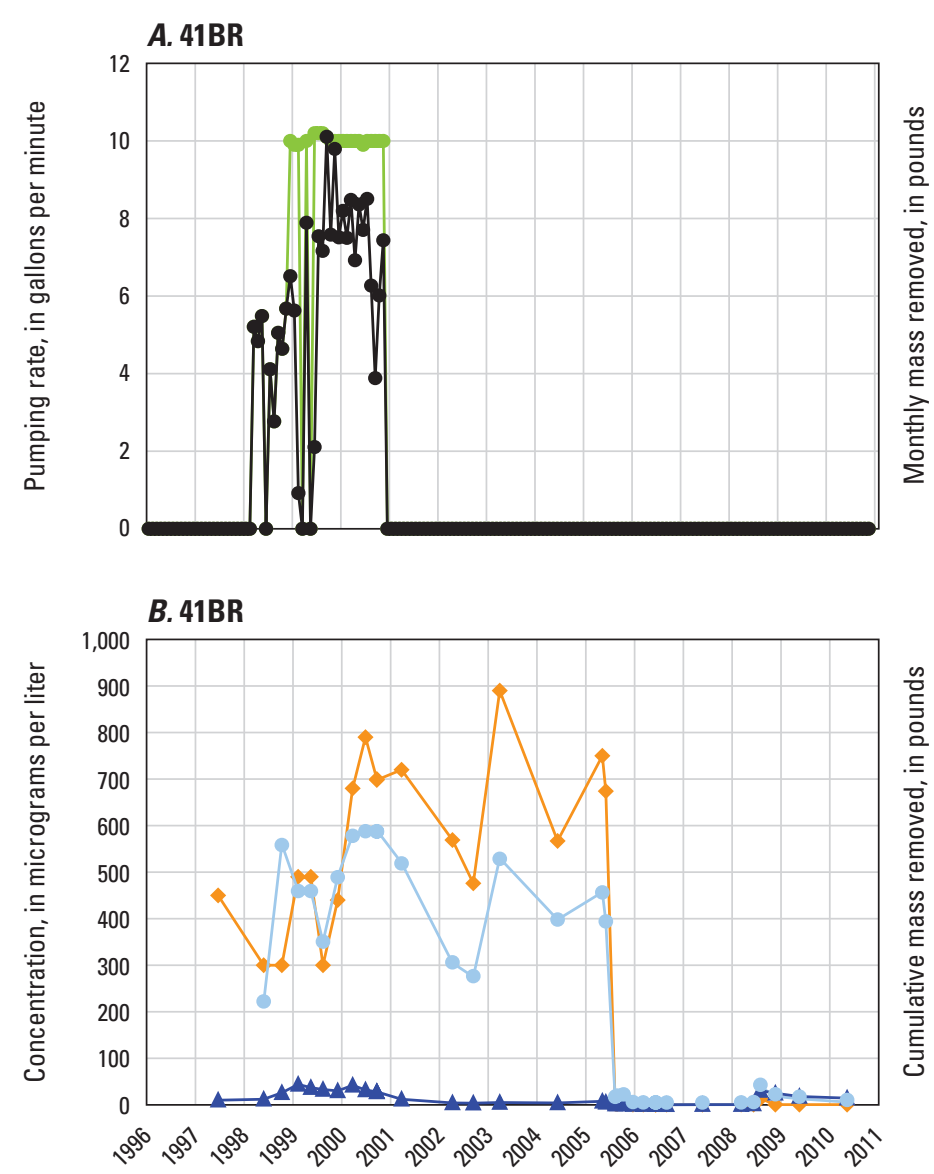

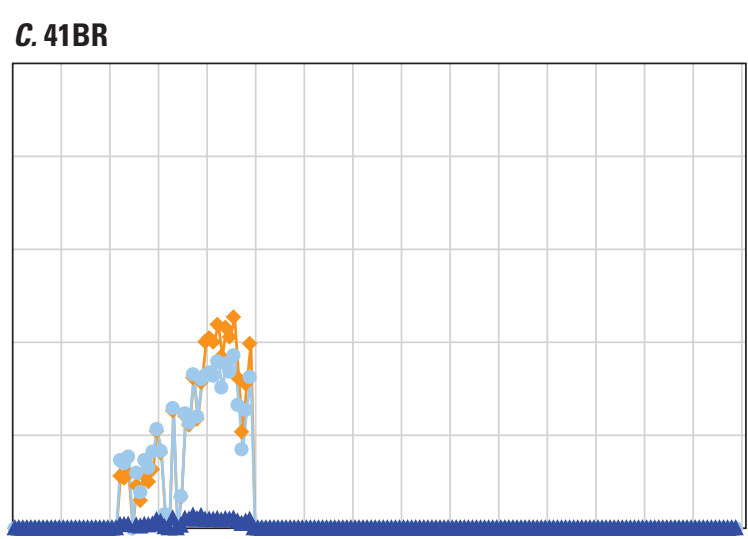

D. 41BR

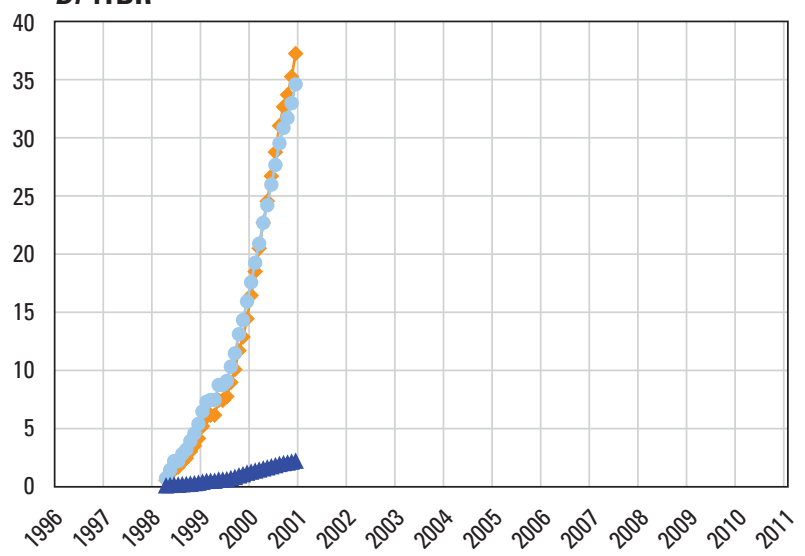

\section{EXPLANATION}

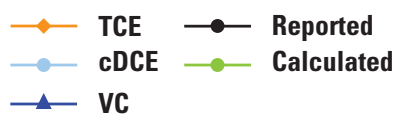

Figure 10. (A) Pumpage rate, $(B)$ chlorinated volatile organic compound (CVOC) concentrations in groundwater samples, $(C)$ monthly recovery of CVOC, and (D) cumulative recovery of CVOCs from recovery well 41BR, Naval Air Warfare Center, West Trenton, NJ, $1996-2010$.

concentration of TCE, cDCE, and $\mathrm{VC}$ in the water for that year (fig. 8C; table 2). The total mass of TCE, cDCE, and VC removed by each recovery wells is summarized in table 4 .

\section{Individual Recovery Wells}

Well 15BR was the only recovery well used during 1996-98 (fig. 8). In late 1998, withdrawals began in the other recovery wells, and concentrations of TCE and CDCE increased in water withdrawn from well 15BR. About half the TCE and CDCE and a third of the VC removed by the P\&T system was in groundwater from recovery well 15BR (table 4).

Removal of CVOCs from recovery well 20BR began in 1998 (fig. 9). Concentrations of cDCE increased soon after withdrawals began but declined sharply in 2002 and again in
2004. About half the cDCE and VC removed by the recovery wells was removed from water from well 20BR.

Recovery well 41BR was used for removal of CVOCs for less than 3 years (fig. 10). The Navy stopped using the well because it caused increased CVOC concentrations in an area that the Navy decided was not part of the long-term objective of the remediation plan.

Recovery from well 45BR began in 1998 (fig. 11). Concentrations of each CVOC stayed constant for the period of record. In 2004, pumping rates increased, and with that, CVOC removal rates increased. About 10 percent of the total TCE removed from the recovery wells was from well 45BR.

Well 48BR is the only recovery well within the Site 3 Plume (fig. 12). Withdrawals from the well began in 1998. The pumping rates and TCE concentrations have decreased over the recovery period. 
A. 45BR

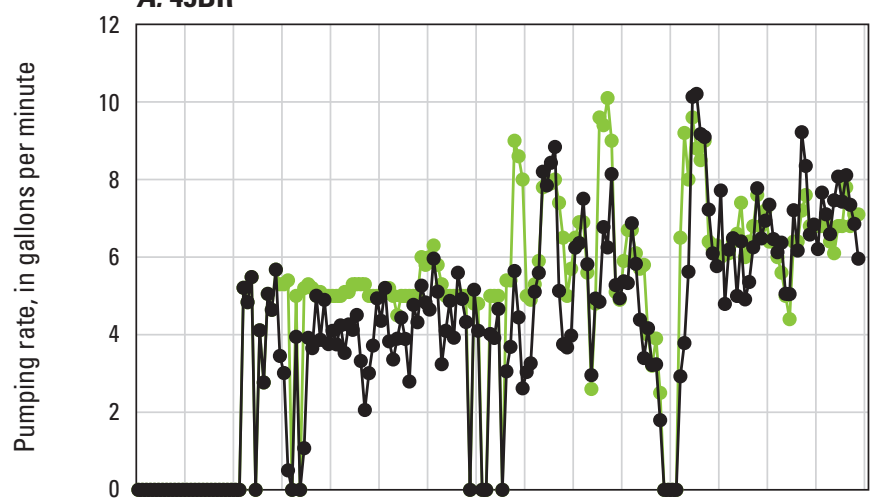

B. 45BR

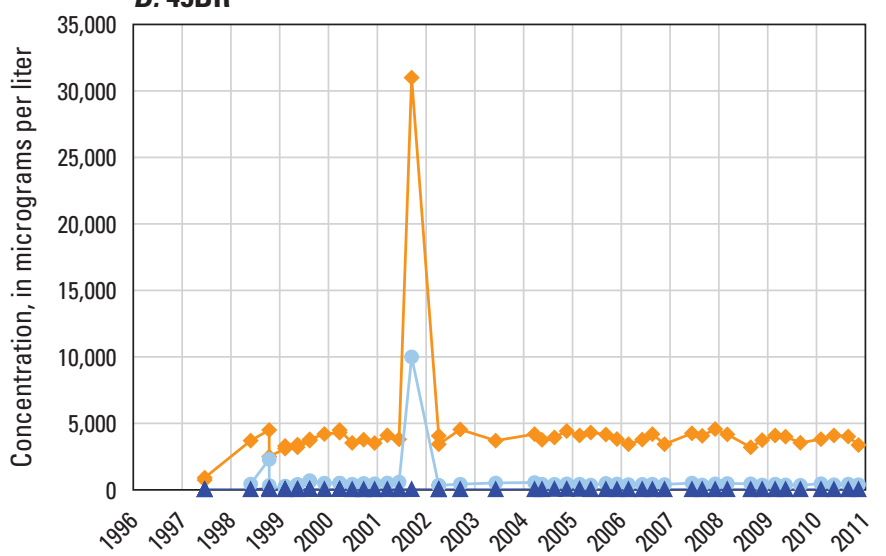

C. 45BR

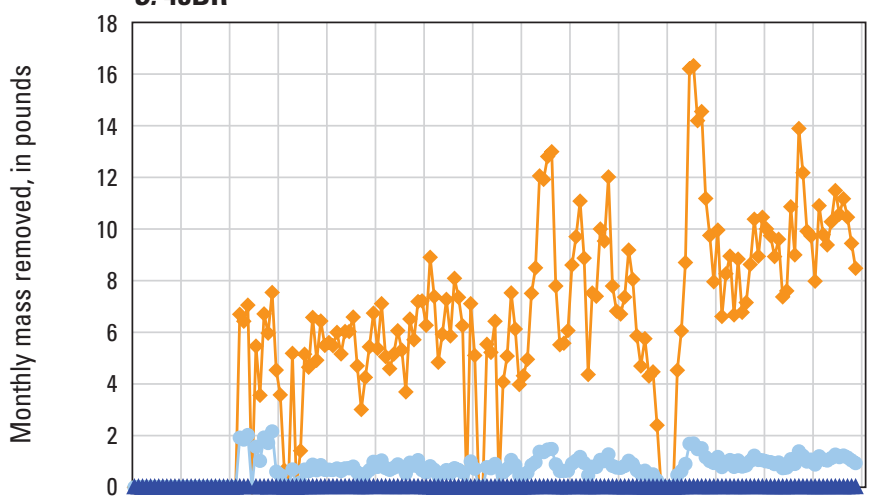

D. 45BR

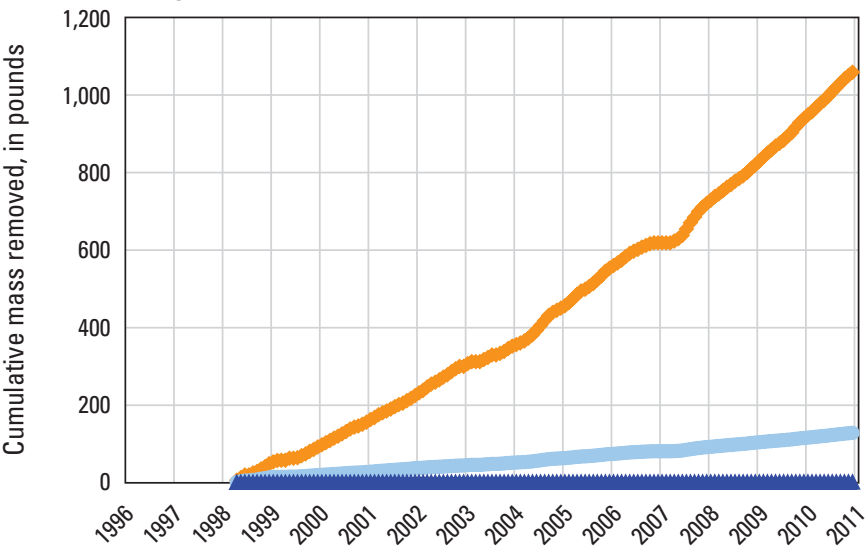

\section{EXPLANATION}

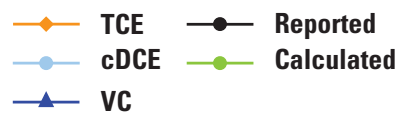

Figure 11. (A) Pumpage rate, $(B)$ chlorinated volatile organic compound (CVOC) concentrations in groundwater samples, $(C)$ monthly recovery of CVOC, and $(D)$ cumulative recovery of CVOCs from recovery well 41BR, Naval Air Warfare Center, West Trenton, NJ, 1996-2010.

Well WDW is the shallowest recovery well (fig. 13). The pump and riser pipe frequently became plugged with deposits likely generated by iron fixing bacteria. The Navy frequently had the pump and riser pipe cleaned. After each cleaning, the pumping rate increased, and CVOC recovery increased. Because of plugging and cleaning, recovery of CVOCs from the well fluctuated between cleanings.

Recovery well BRP-02 was put into service in 2001 (fig. 14). Concentrations of $\mathrm{CDCE}$ and VC in water samples from this well were greater than the concentration of TCE, and concentrations of $\mathrm{CDCE}$ and $\mathrm{VC}$ decreased over time. More $\mathrm{VC}$ was removed than TCE by this recovery well (table 3 ).

Recovery well 22BR began withdrawing groundwater in 2000 (fig. 15) in order to reduce contaminated groundwater discharges into the Gold Run culvert (fig. 1) at the south side of the NAWC. Pumping rates increased during 2000-10. This well has removed the least CVOCs of the P\&T system, but it is essential in reducing contaminated groundwater discharge to the lower reach of Gold Run.

Recovery well 56BR began withdrawals in 2004 (fig. 16). The well was put into operation because TCE concentrations were in excess of $200,000 \mu \mathrm{g} / \mathrm{L}$, which can indicate the presence of pure phase TCE nearby. Soon after pumping began, TCE concentrations decreased to about $20,000 \mu \mathrm{g} / \mathrm{L}$. The high recovery rate of 2004-05 decreased substantially during 2006-09. Nearly 10 percent of the TCE removed by the P\&T system was in water from this recovery well.

Recovery wells 8BR and 29BR began operation February 18,2010 ; the purpose was to intercept contaminated groundwater that would otherwise discharge to the reach of the West Ditch between recovery wells 8BR and 56BR (fig. 1). With only 10.5 months of data, it is too soon to assess the data. 

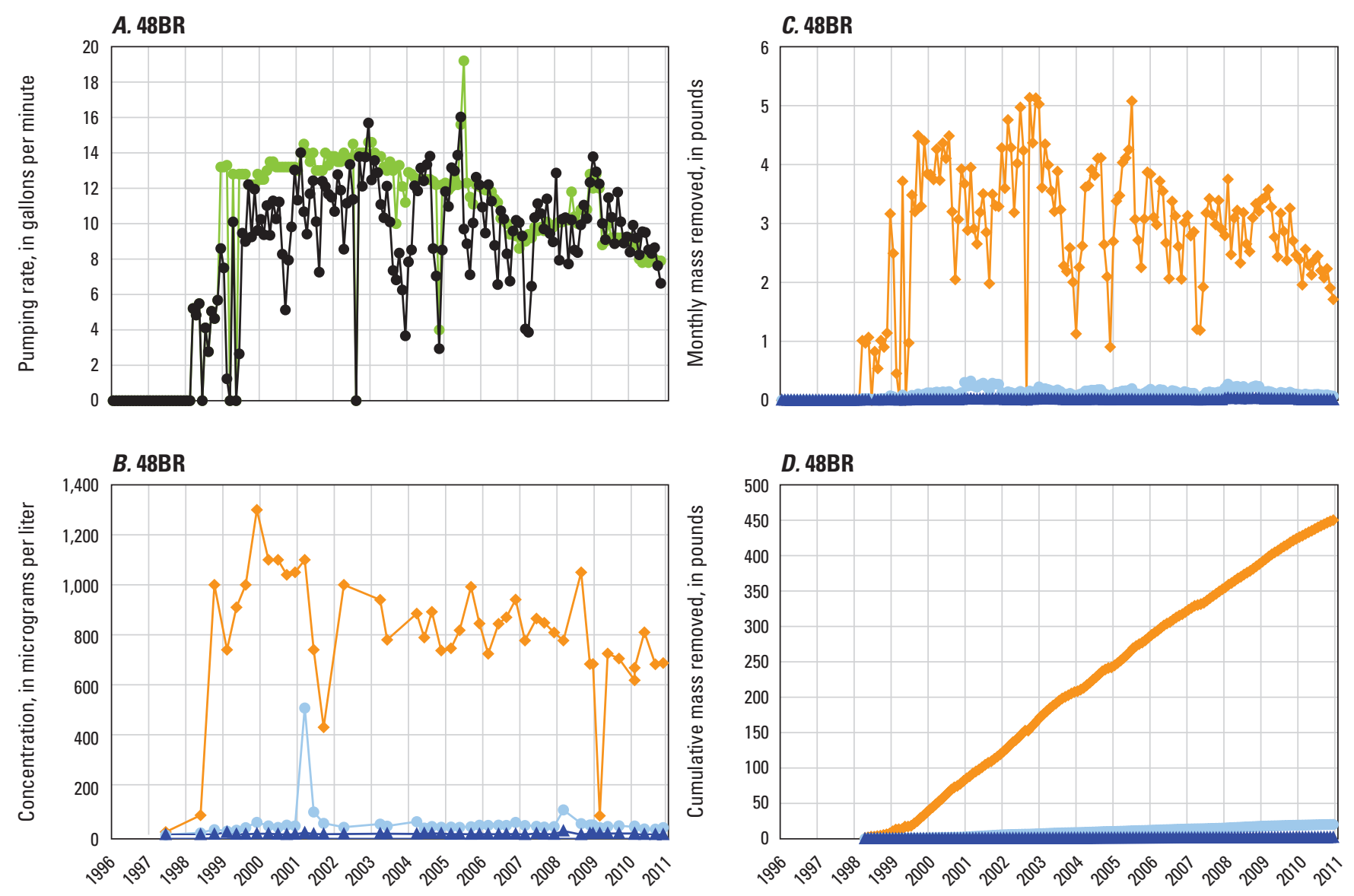

\section{EXPLANATION}

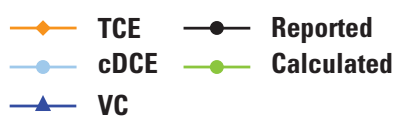

Figure 12. (A) Pumpage rate, $(B)$ chlorinated volatile organic compound (CVOC) concentrations in groundwater samples, $(C)$ monthly recovery of CVOC, and $(D)$ cumulative recovery of CVOCs from recovery well 41BR, Naval Air Warfare Center, West Trenton, NJ, 1996-2010.

\section{All Recovery Wells}

A comparison of the mass of TCE, cDCE, and VC removed from the active recovery wells (fig. 17) shows that most TCE (57 percent) was removed by well 15BR and most cDCE and VC ( 90 and 88 percent, respectively) were recovered by pumping wells 15BR and 20BR. More CVOCs were removed by pumping these two wells than by pumping the other seven wells.

The monthly mass of TCE removed by all recovery wells ranged from 0 to $137 \mathrm{lbs}$ with an average of about $50 \mathrm{lbs}$ (fig. 18A). The monthly mass of cDCE removed ranged from 0 to $467 \mathrm{lbs}$ with an average of $99 \mathrm{lbs}$ (fig. 18B). The monthly mass of $\mathrm{VC}$ removed ranged from 0 to $113 \mathrm{lbs}$ with an average of $17 \mathrm{lbs}$ (fig. 18C). The low recovery rate during 1996 to 1998 was because only well 15BR was operating. Starting in
1999, TCE, cDCE, and VC monthly removal rates increased dramatically because of the increased number of recovery wells. The suite of recovery wells removed TCE, cDCE, and $\mathrm{VC}$ that was located in the highly transmissive fractures and TCE that was adsorbed to the walls of the fractures. For 7 years during 1999-2005, the monthly removal of TCE was the greatest for the period of record. For 3 years during 1999 to 2001, the monthly removal of cDCE was greatest for the period of record. While for only 2 years during 1999-2000, the monthly removal of $\mathrm{VC}$ was greatest for the period of record. These data show that $\mathrm{VC}$ in the high transmissive fractures was removed more quickly than $\mathrm{cDCE}$, and $\mathrm{CDCE}$ was removed more quickly than TCE.

Since 2005, recovery of the three CVOCs has decreased. This long-recognized "tailing" phenomenon is characteristic of most P\&T systems (U.S. Environmental Protection Agency, 

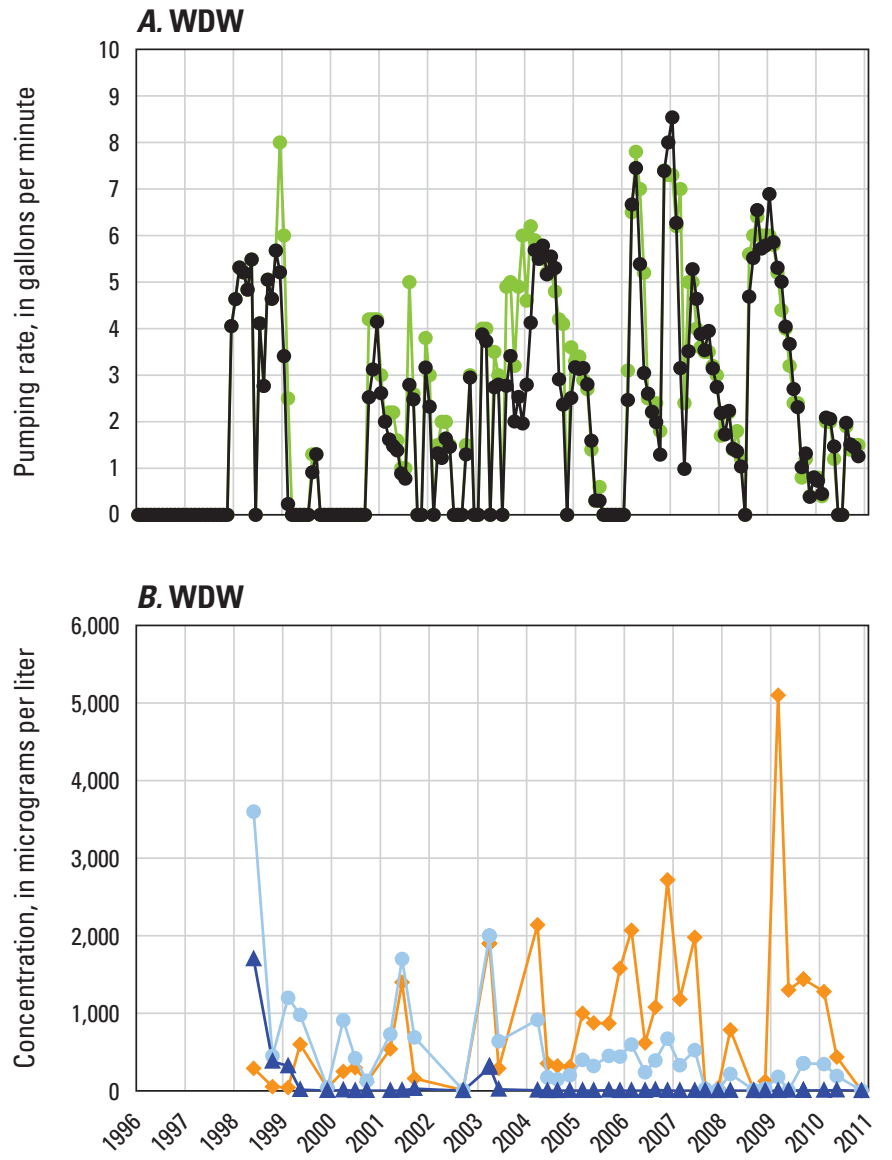
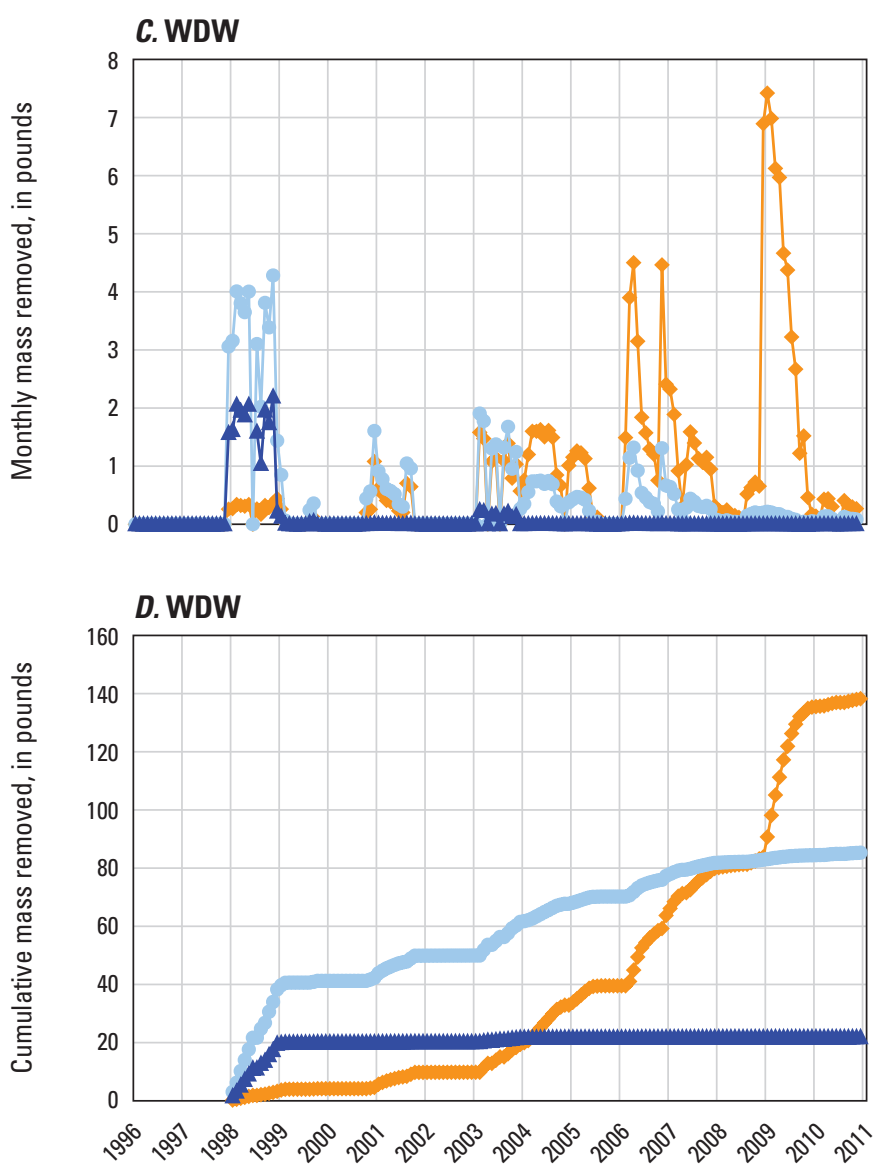

\section{EXPLANATION}

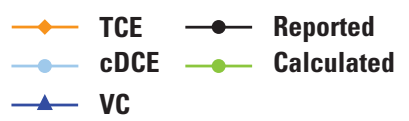

Figure 13. (A) Pumpage rate, $(B)$ chlorinated volatile organic compound (CVOC) concentrations in groundwater samples, $(C)$ monthly recovery of CVOC, and $(D)$ cumulative recovery of CVOCs from recovery well WDW, Naval Air Warfare Center, West Trenton, NJ, 1996-2010.

1996). The tailing is interpreted to mean that the TCE, cDCE, and $\mathrm{VC}$ that has been recovered during 2005-09 has migrated from the low transmissive fractures and from rock matrix that is more removed from the high transmissivity fracture into the high transmissivity fractures.

The sums of the masses of CVOCs removed by pumping the recovery wells are TCE, 8,983 lbs; cDCE, 17,798 lbs; and VC, 3,056 lbs (table 2, fig. 19).

\section{Mass of Original TCE Removed}

The mass of original TCE that was removed each month was calculated by converting the masses of TCE, CDCE, and $\mathrm{VC}$ from pounds to the number of moles of each compound (table 2). The number of moles was summed to show the monthly (fig. 20A) and cumulative number of moles (fig. 20B) removed from groundwater withdrawn from recovery wells. The cumulative number of moles removed was converted to show the pounds of original TCE that was removed (fig. 20C).

The monthly number of moles of TCE removed ranged from 0 to 473 with a mean of 173 . The monthly number of moles of cDCE removed ranged from 0 to 2,186 with a mean of 465 . The monthly number of moles of VC removed ranged from 0 to 818 with a mean of 124 . The sum of the monthly number of moles of CVOC removed ranged from 0 to 3,335 with an average of 762 .

The cumulative number of moles of TCE removed during the period of operation was 31,012 ; cDCE was 83,269 ; and $\mathrm{VC}$ was 22,180 . The cumulative number of moles of original TCE removed was 136,461 (table 2, fig. 20B). The cumulative 


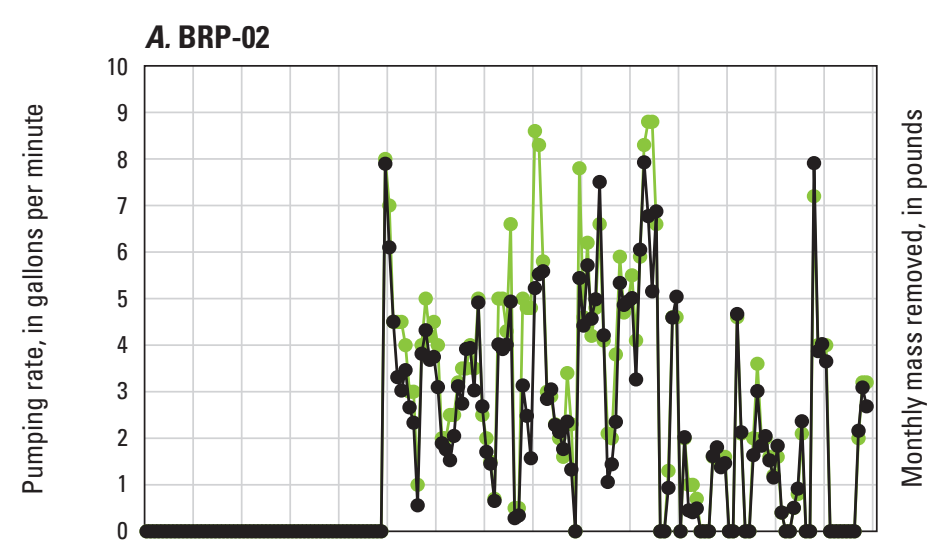

\section{BRP-02}
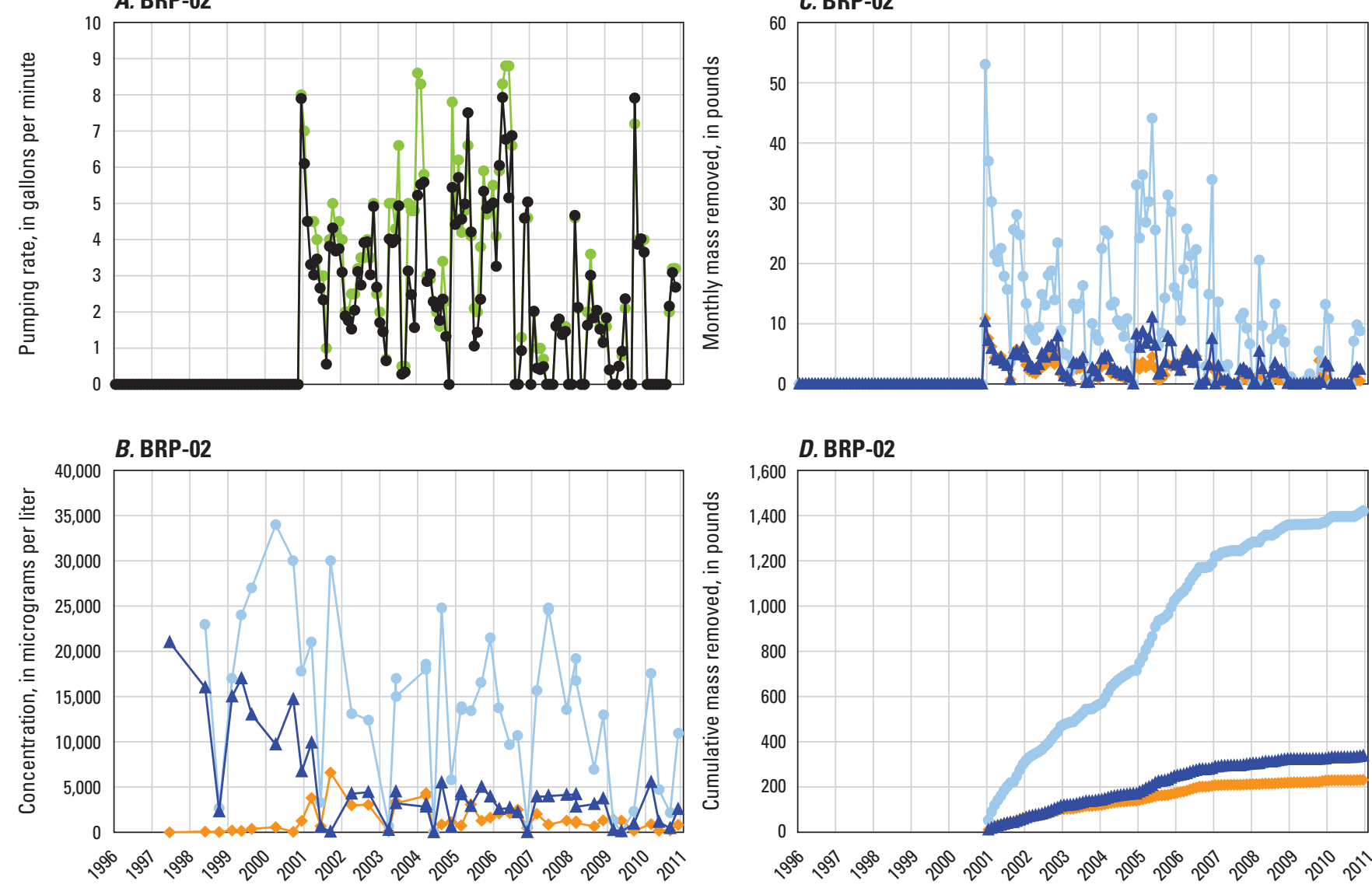

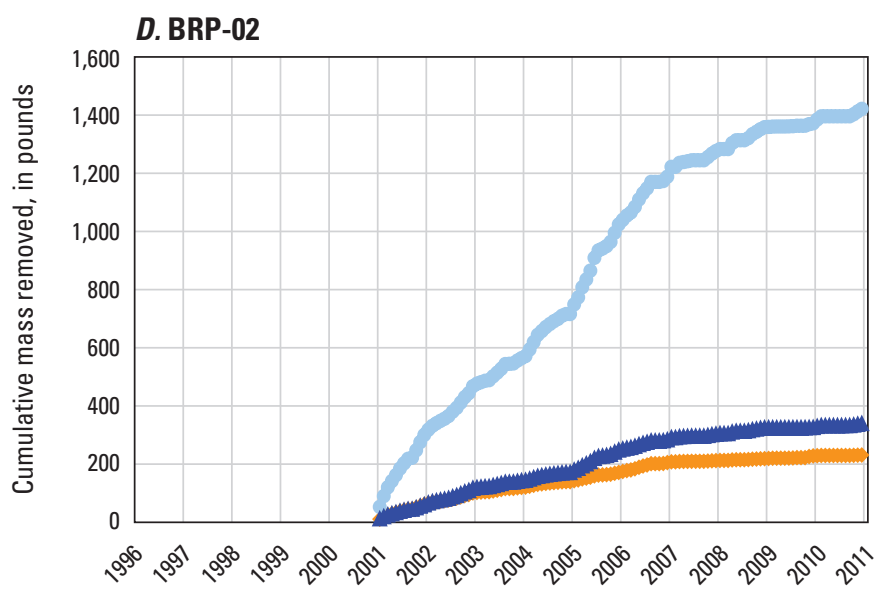

EXPLANATION

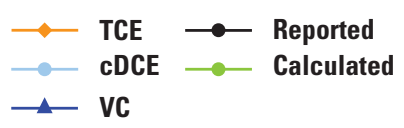

Figure 14. $A B C D$

number of moles of original TCE was converted to obtain the mass of original TCE removed by the P\&T recovery system; 39,528 lbs of original TCE has been removed by using Method 2.

The Navy simply summed the masses of TCE, cDCE, and VC determined using Method 1 to report the total mass of CVOCs removed each month, as well as the cumulative mass of CVOCs removed. As stated previously the result of this simple addition is included for illustration purposes. The total cumulative mass of CVOCs removed calculated by using simple addition and based on Method 2 is 29,837 lbs. 

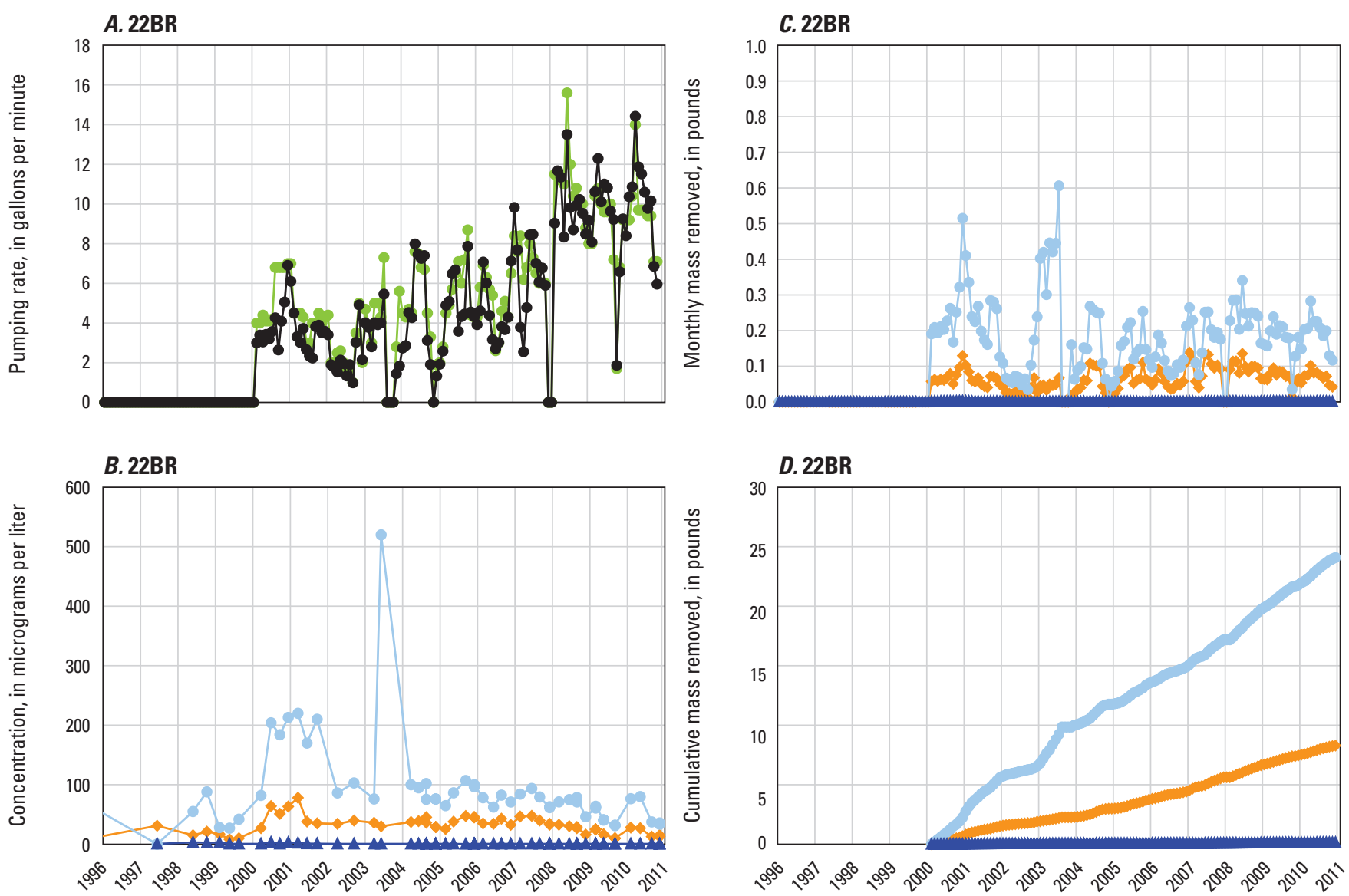

\section{EXPLANATION}

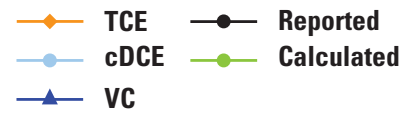

Figure 15. (A) Pumpage rate, $(B)$ chlorinated volatile organic compound (CVOC) concentrations in groundwater samples, $(C)$ monthly recovery of CVOC, and $(D)$ cumulative recovery of CVOCs from recovery well 41BR, Naval Air Warfare Center, West Trenton, NJ, 1996-2010. 


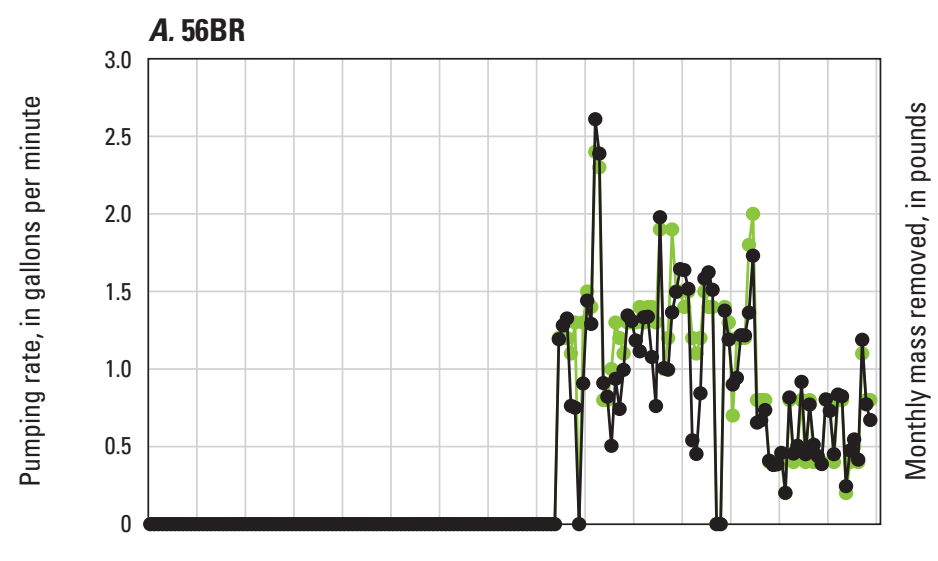

C. $56 \mathrm{BR}$
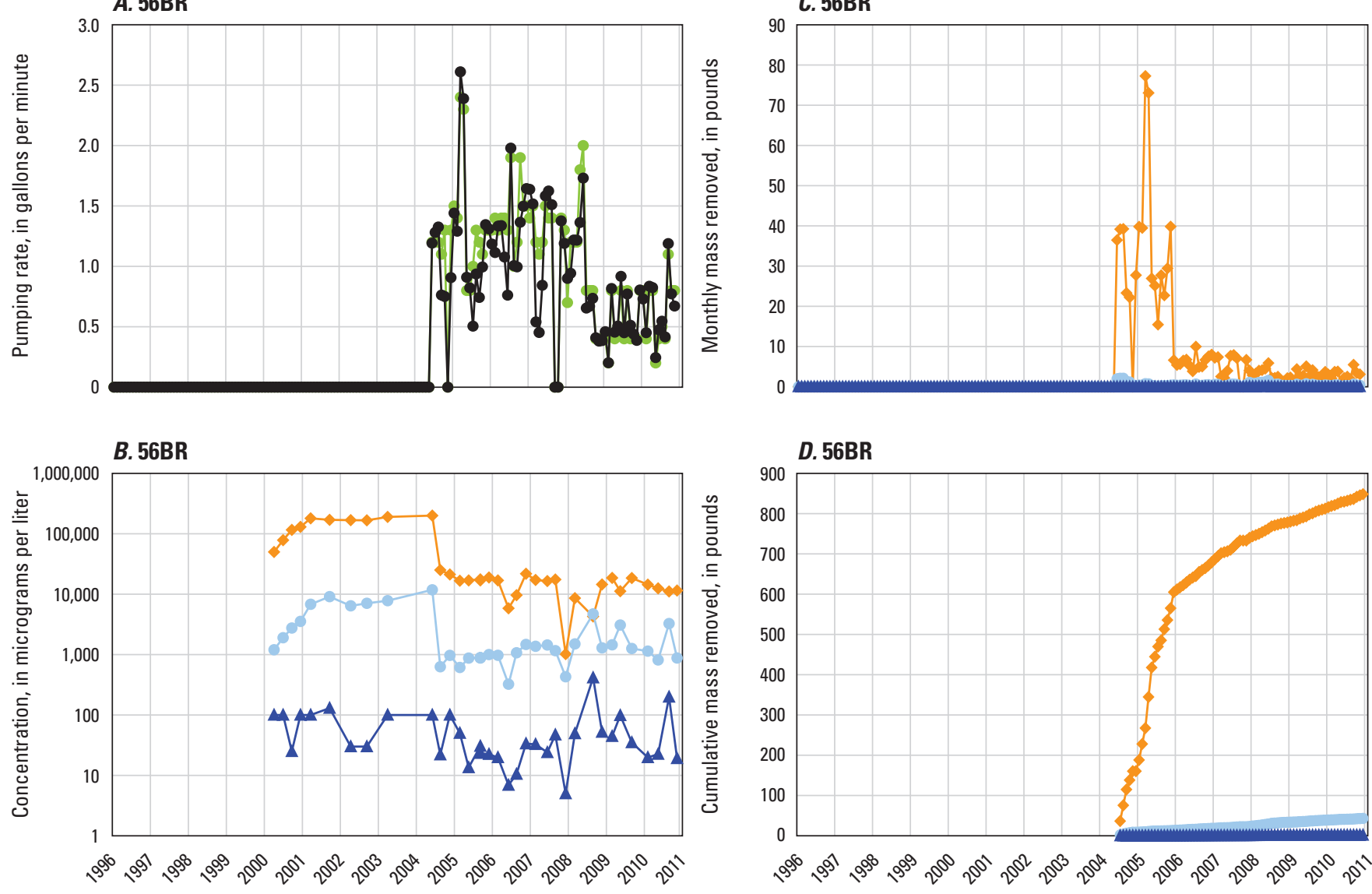

\section{EXPLANATION}

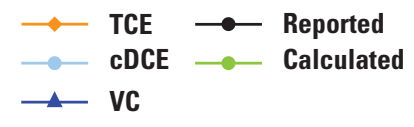

Figure 16. (A) Pumpage rate, $(B)$ chlorinated volatile organic compound (CVOC) concentrations in groundwater samples, $(C)$ monthly recovery of CVOC, and $(D)$ cumulative recovery of CVOCs from recovery well 41BR, Naval Air Warfare Center, West Trenton, NJ, 1996-2010. 

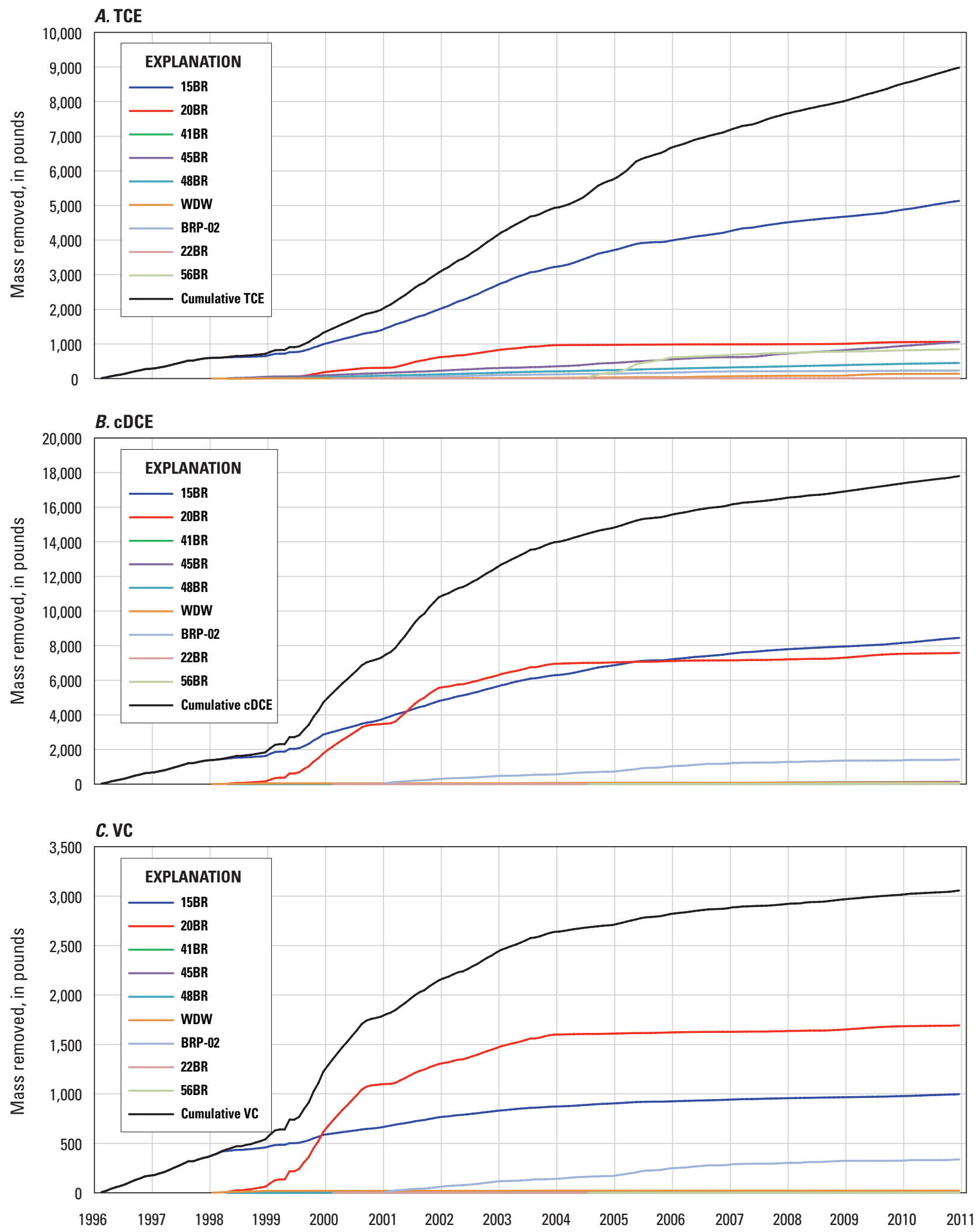

Figure 17. Mass of $(A)$ trichloroethylene (TCE), $(B)$ cis-dichloroethylene (CDCE), and (C) vinyl chloride (VC) removed from each recovery well, Naval Air Warfare Center, West Trenton, NJ, 1996-2010. 

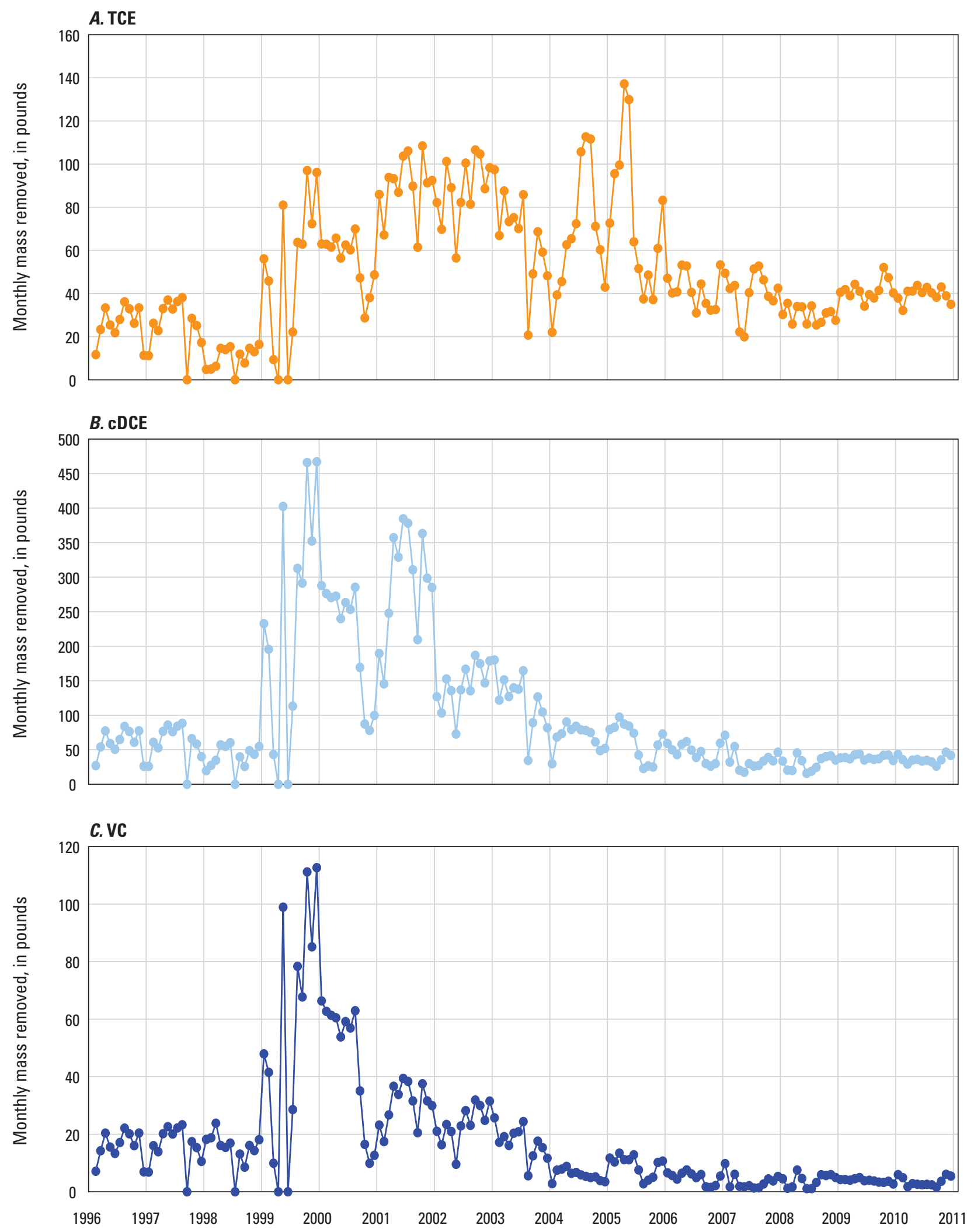

Figure 18. Monthly mass of $(A)$ trichloroethylene (TCE), $(B)$ cis-dichloroethylene (cDCE), and $(C)$ vinyl chloride (VC) removed based on withdrawals from the recovery wells, Naval Air Warfare Center, West Trenton, NJ, 1996-2010. 


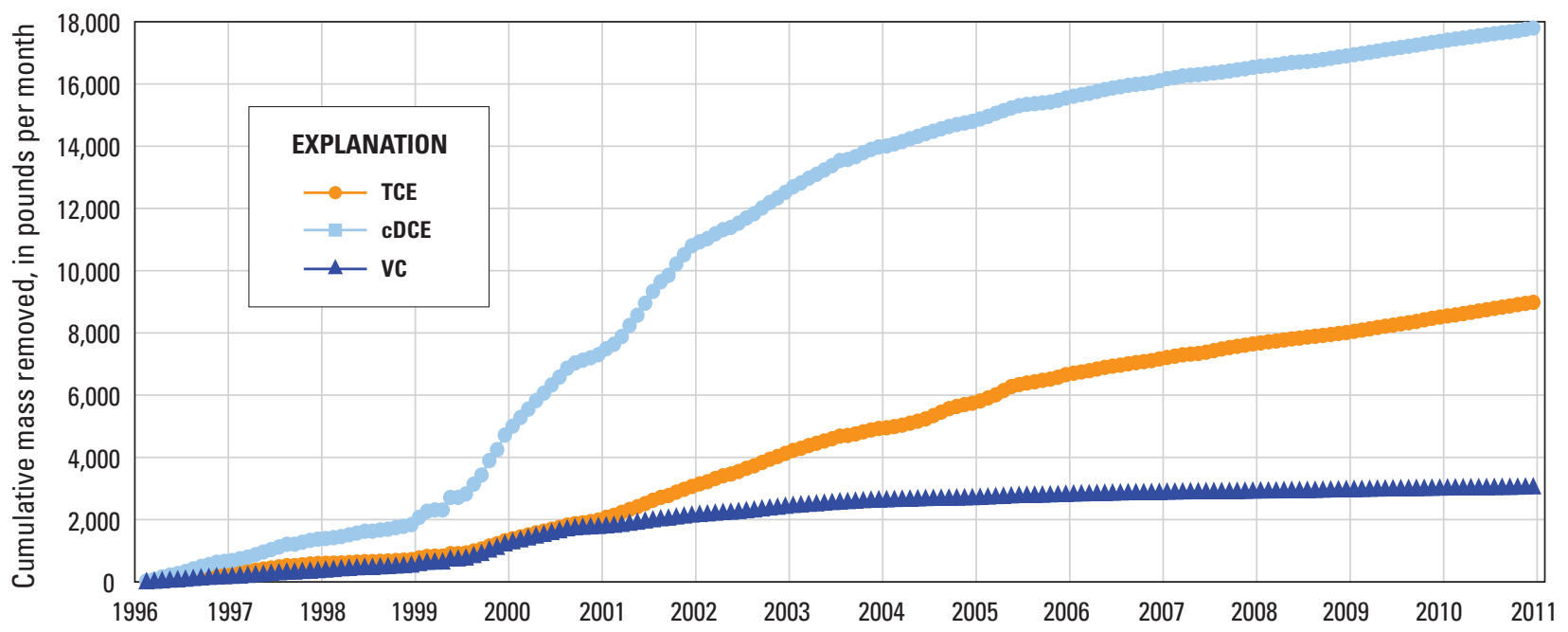

Figure 19. Cumulative mass of trichloroethylene (TCE), cis-dichloroethylene (CDCE), and vinyl chloride (VC) removed based on withdrawals from the recovery wells, Naval Air Warfare Center, West Trenton, NJ, 1996-2010. 

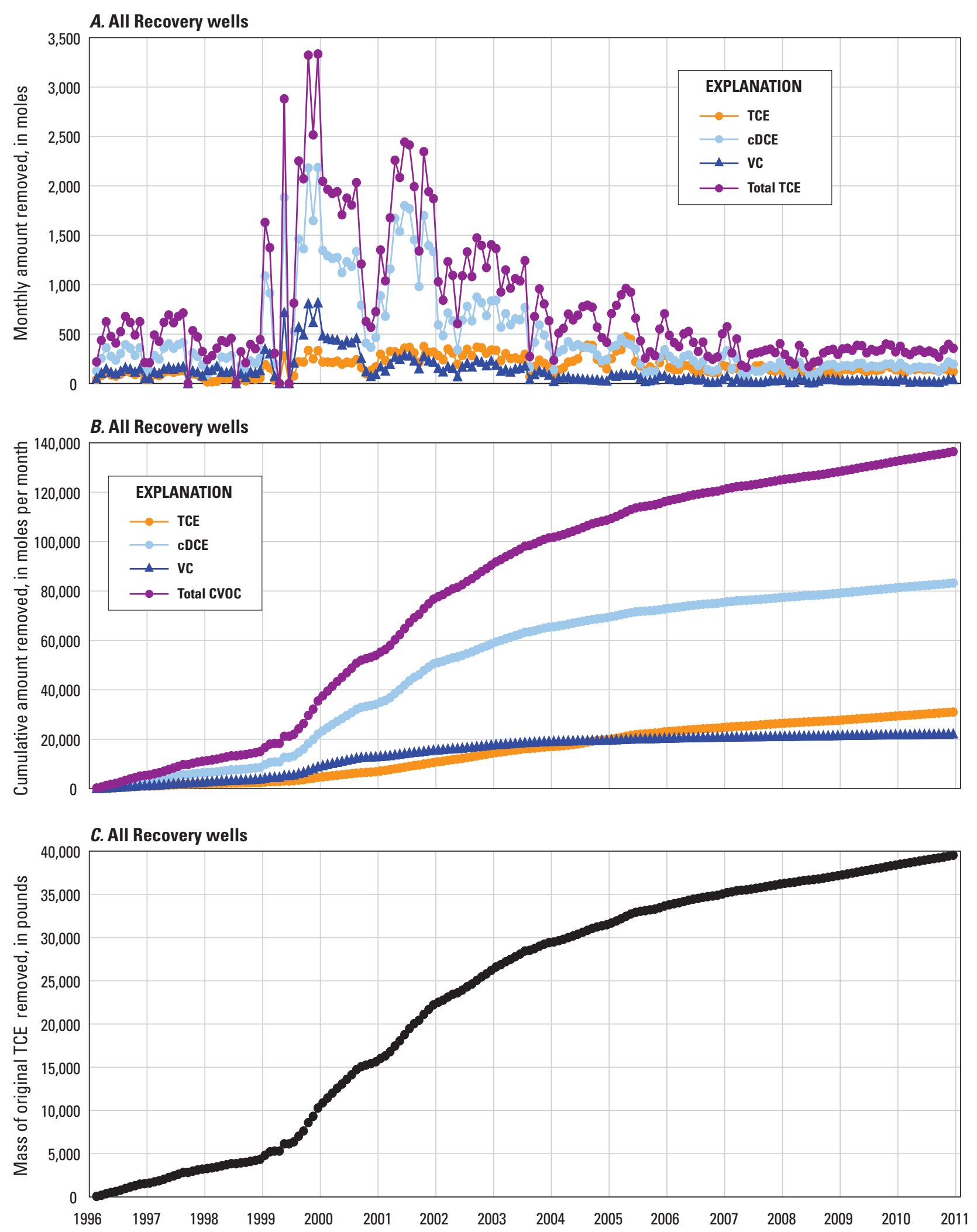

Figure 20. Amount of trichloroethylene (TCE), cis-dichloroethylene (CDCE), and vinyl chloride (VC) and total original TCE removed (A) monthly, $(B)$ cumulatively, and $(C)$ mass of original TCE removed from groundwater by pumping the recovery wells, Naval Air Warfare Center, West Trenton, NJ, 1996-2010. 


\section{Results of Method 3: Removal Based on Maximum of Methods 1 and 2}

For Method 3, the greater value of the monthly number of moles for TCE, cDCE, and VC removed was selected from Methods 1 or Method 2 (fig. 21; table 5, at end of report).

Method 1, in general, resulted in the greater monthly number of moles removed during 1996-98, and Method 2, in general, resulted in the greater monthly number of moles removed during 1999-2003. The monthly numbers of moles removed during 2004-10 were similar for both calculation methods.

The summed monthly mass of original TCE ranged from 52 to about $966 \mathrm{lbs}$ with a mean of $259 \mathrm{lbs}$ (table 5; fig. 22A). The cumulative mass of original TCE removed, using Method 3, during 1996-2010 was 46,452 lbs (fig. 22B). 

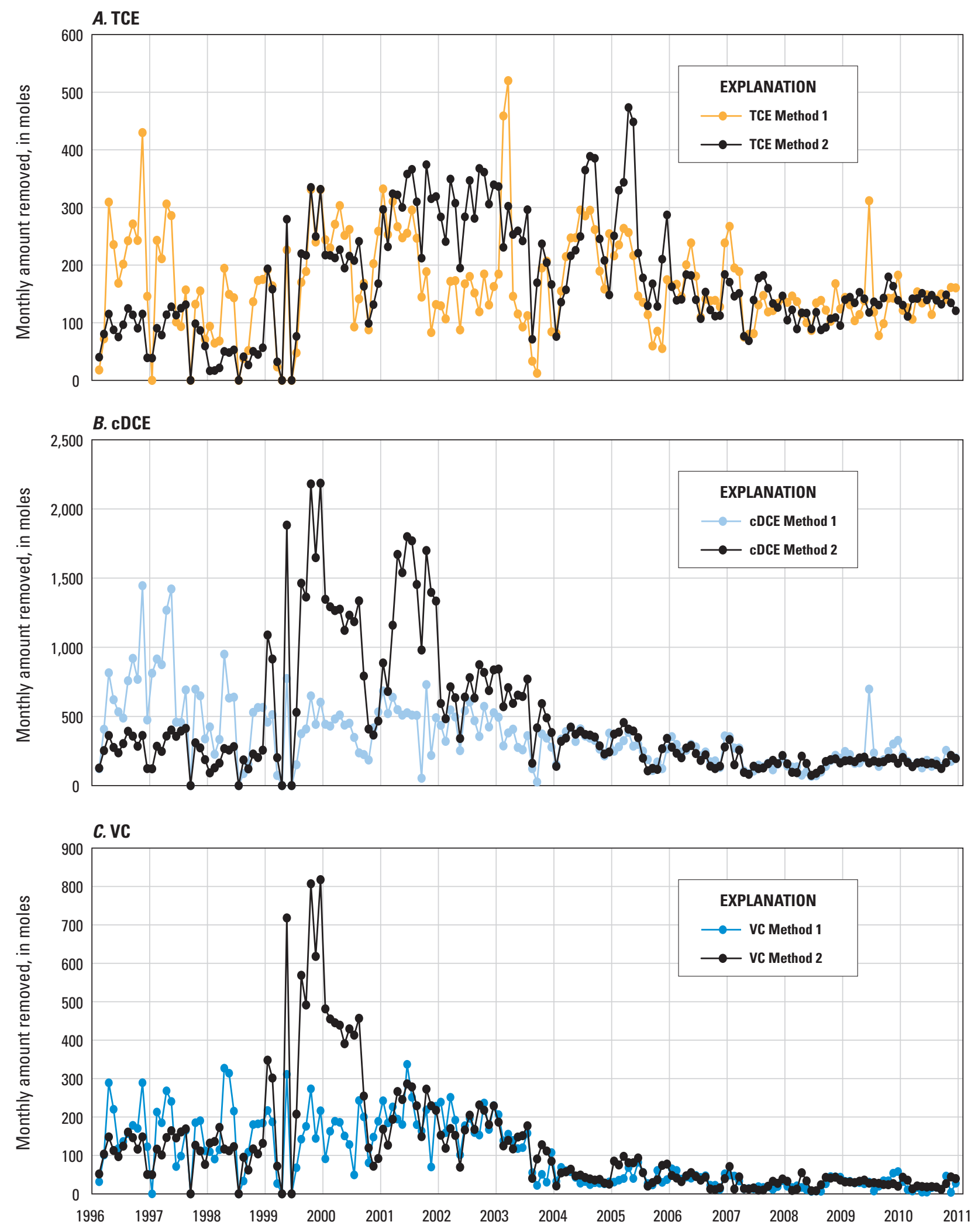

Figure 21. Amount of $(A)$ trichloroethylene (TCE), $(B)$ cis-dichloroethylene (cDCE), and $(C)$ vinyl chloride (VC) removed monthly from groundwater using Method 1 from influent to the Pump and Treat building and using Method 2 from groundwater pumped from the recovery wells, Naval Air Warfare Center, West Trenton, NJ, 1996-2010. 

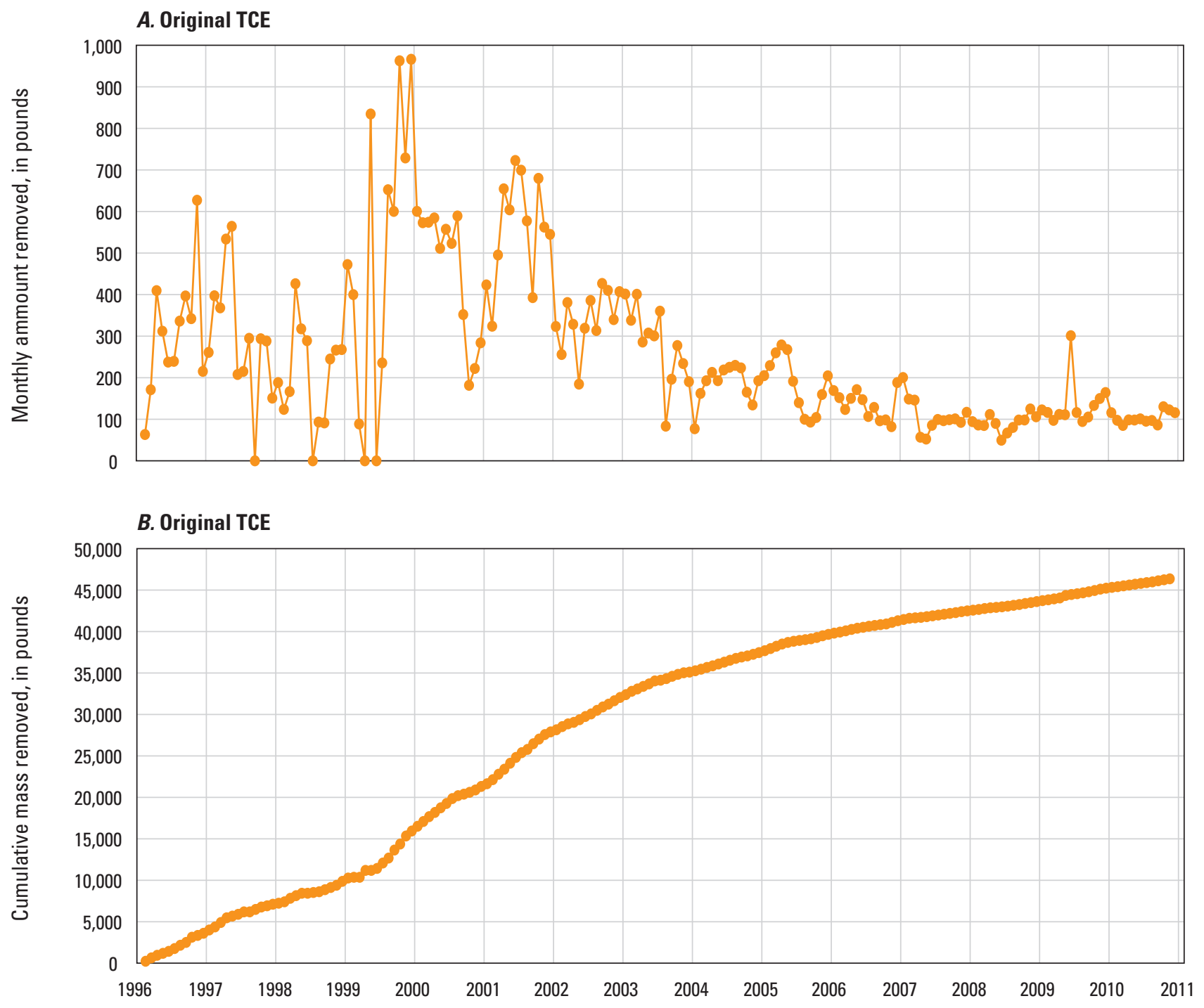

Figure 22. Number of pounds of original trichloroethylene (TCE) removed $(A)$ monthly and $(B)$ cumulatively using Method 3, Naval Air Warfare Center, West Trenton, NJ, 1996-2010. 


\section{Discussion of Difference in Masses Based on Methods}

Masses of TCE, cDCE, and VC or origin TCE removed from groundwater by the P\&T system should be the same whether using Method 1 or Method 2. The calculated masses removed are not similar. During 1996-98, the masses removed as calculated by Method 1 were greater than the masses calculated by Method 2 (fig. 21). During 1999-2004, the masses removed by Method 1 were sometimes much greater, sometimes equal, and sometimes much less than the masses removed by Method 2. During 2005-10, the masses removed by Method 1 and Method 2 were nearly identical. Plausible reasons for why the masses are different include (1) changes in concentrations of TCE, cDCE, and VC in the transmission pipe between the water sample collection locations at the recovery wells and in the P\&T building; (2) changes in the volume of water between the two water sampling locations; or (3) differences in the laboratory analyses of water samples from the two sampling locations. It is unlikely that changes occurred in concentrations of the three compounds or volume of water between the two sampling locations because the changes would likely be constant over time and the changes are not constant with time.

It is likely that the difference in the monthly masses removed is a result of differences in the analytical results from the multiple laboratories that analyzed the water samples. During 1996-98 the influent water samples were analyzed by one laboratory, and the recovery well water samples were analyzed by another laboratory. The laboratory that analyzed influent water samples reported higher concentrations than the laboratory that analyzed water samples from the one active recovery well. During 1999-2004, influent water samples from the P\&T building were analyzed by two laboratories, and CVOC concentrations remained relatively constant from one year to the next. During the same time, recovery well water samples were analyzed by five laboratories. Each laboratory analyzed the water samples for about 1 year. Some analytical results from the five laboratories showed wide fluctuations in TCE, cDCE, and VC concentrations from year to year. The fluctuations from year to year during 1999-2004 may be correct, but the fluctuations may also be a function of changes in analytical, calibration, and procedural methods between the laboratories. During 2005-10, two laboratories were used to analyze the influent, and one of those laboratories was used to analyze the recovery wells' water samples. Masses removed are nearly identical.

One might ask, are the results from Method 1 or Method 2 more accurate? Method 1 shows high rates of removal of TCE and cDCE during the first few years of operation with lesser removal rates as time passes (fig. 21). This characteristic is normal for P\&T systems. Method 2 shows a high rate of removal of TCE, $\mathrm{CDCE}$, and $\mathrm{VC}$ when the P\&T system was expanded from one recovery well to seven recovery wells in 1999 and then shows lesser removal of each compound as time passes (fig. 21). This too is normal for a P\&T system. During 1999-2002, at the time the P\&T system expanded, Method 1 showed an increase in masses removed of cDCE or VC as well as an increase in masses removed of TCE. It is believed that Method 2 better reflects the increase in removal of TCE, cDCE, and VC with the startup of the additional seven recovery wells.

Calculations of the mass of original TCE removed, using Methods 1, 2, and 3, resulted in 32,381 lbs, 39,535 lbs, and 46,452 lbs, respectively (table 6; fig. 23). Historically, the Navy used Method 1 to obtain monthly masses of TCE, cDCE, and $\mathrm{VC}$, then summed the masses to obtain the total mass of CVOCs that was removed, 24,805 lbs. Summing of the masses of three CVOCs is not a preferred manner of obtaining a value for original TCE; it is used for comparison purposes. With Methods 3, it is possible to show that the P\&T system removed 21,647 lbs more (186 percent) of original TCE than was stated in the monthly reports.

Lacombe (2007) estimated that from 9,334 to 152,600 lbs of original TCE were in the subsurface in 2006. During 2006-10, the P\&T system removed an average of about 1,200 lbs per year (fig. 21). The rate of removal of the CVOC by P\&T will continue to decrease in the future. The P\&T system as designed has controlled the off-site movement of contaminated groundwater toward the nearby neighborhood and the few supply wells in the neighborhood. The Navy annually monitors water quality in observation wells between the NAWC and the neighborhood to verify that no contaminant is migrating into the neighborhood. The P\&T system also has reduced, but not eliminated, the discharge of contaminated groundwater to the West Ditch and the west branch of Gold Run, both intermittent streams. This problem has been addressed by increasing groundwater withdrawals from recovery wells near the intermittent stream, adding new recovery wells, and conducting research to determine the exact section of the intermittent stream where contaminated groundwater discharges.

Table 6. Mass of trichloroethylene (TCE), cis-dichloroethylene (cDCE), vinyl chloride (VC), and original TCE removed by the Pump and Treat system, determined using Methods 1, 2, and 3, Naval Air Warfare Center, West Trenton, NJ, 1996-2010.

\begin{tabular}{lccc}
\hline & $\begin{array}{c}\text { Method 1 } \\
\text { (pounds) }\end{array}$ & $\begin{array}{c}\text { Method 2 } \\
\text { (pounds) }\end{array}$ & $\begin{array}{c}\text { Method 3 } \\
\text { (pounds) }\end{array}$ \\
\hline TCE & 8,666 & 8,985 & 10,602 \\
cDCE & 13,689 & 17,801 & 21,029 \\
VC & 2,456 & 3,056 & 3,496 \\
Original TCE & 32,381 & 39,535 & 46,452 \\
Simple sum & 24,805 & 29,837 & 35,053 \\
\hline
\end{tabular}




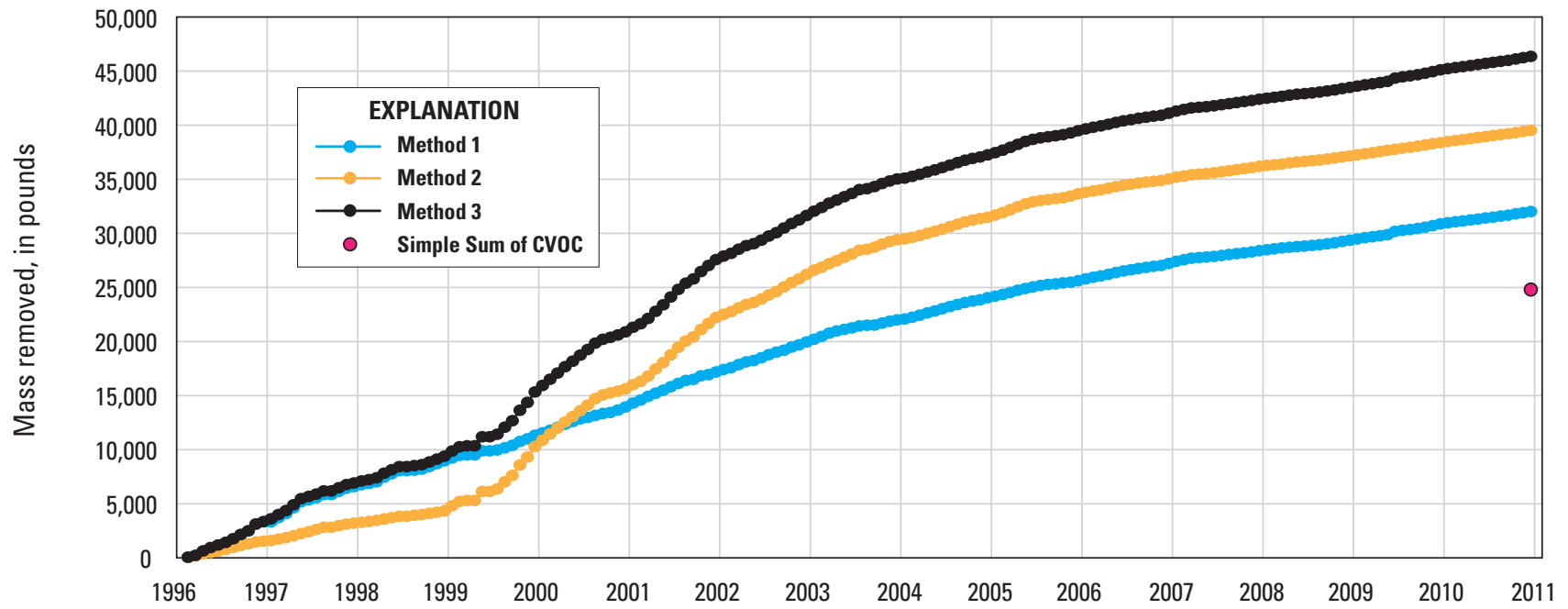

Figure 23. Mass removed of original trichloroethylene (TCE) using Methods 1, 2, and 3 and reported simple sum of the mass of TCE, cis-dichloroethylene (cDCE), and vinyl chloride (VC) removed, Naval Air Warfare Center, West Trenton, NJ, $1996-2010$.

\section{Summary and Conclusions}

A P\&T system was designed in the early 1990 s to remove and contain CVOCs in the aquifer that underlies the former NAWC property in West Trenton, NJ. The system was designed to create a cone of depression that would prevent movement of CVOC contaminated groundwater to the surrounding neighborhood where CVOCs might contaminate domestic supply wells. The P\&T system was also designed to prevent contaminated groundwater from discharging to surface water, thus contaminating the ecological water supply. Lastly, the system was designed to remove TCE and its degradation products cDCE and VC from the subsurface. The P\&T system consists of 14 recovery wells, underground transmission lines from the recovery wells to the P\&T stripper building, and the P\&T air stripper building.

The Navy used TCE at NAWC as a heat transfer agent during tests of jet engines during 1953-95. TCE storage tanks, transmission lines, heat transfer units, and other related plumbing held 25,000 gallons $(304,607 \mathrm{lbs})$ of TCE. TCE occasionally leaked from the plumbing system or was disposed if it became contaminated with water from condensation. The mass of TCE that leaked or was disposed of at the former NAWC is unknown. Estimates indicate that the amount of TCE that leaked or was disposed of ranged from 6,092 to 676,166 lbs.

Reducing conditions exist in the bedrock aquifer at the NAWC. The conditions result, in part, from the carbon-rich mudstone rocks of the region and, in part, from the jet fuel that leaked or spilled at the NAWC. The reducing environment enabled much of the TCE to biodegrade to cDCE, VC, and ethane. Concentrations of TCE, CDCE, and VC in water samples have decreased in most recovery wells similar to decreases in most monitoring wells. The decrease is in part a result of contaminant removal by the P\&T system as well as other activities at NAWC, including monitored natural attenuation, enhanced biodegradation, thermal conductive heating, and removal of contaminated soil. As much as 152,600 lbs of original TCE was previously estimated to be present in the bedrock at NAWC.

About 250,000,000 gallons of contaminated groundwater was pumped and treated at NAWC during 1996-2010. Three methods were used to calculate the masses of TCE, cDCE, and VC, as well as the mass of original TCE, removed by the P\&T system. Method 1 is based on the volume of influent to the P\&T building and the concentration of each CVOC in influent to the P\&T building. Method 2 is based on the volume of groundwater removed from each recovery well and the concentration of each CVOC in water samples from each recovery well. Method 3 consists of choosing the greater value from Method 1 or 2 . The mass of original TCE removed by Methods 1, 2, and 3 are about 31,000 lbs, 38,000 lbs, and 45,000 lbs, respectively.

In theory, by using Methods 1 and 2, the calculated masses of TCE, cDCE, VC, and original TCE that were removed each month should be nearly identical. However, comparison of the two methods reveals that Method 1 resulted in more original TCE removed during 1996-98 than Method 2, and Method 2 resulted in more original TCE removed during 1999-2004 than Method 1. The two methods resulted in about the same amount of original TCE removed during 2005-10. The variations in calculated masses are believed to be the result of using multiple laboratories to analyze the water samples. 
Large masses of CVOC were removed when the P\&T system was first started in 1996 and again when the P\&T system was expanded in 1999. During the past 5 years, the monthly removal rates have decreased substantially. The large masses initially removed were TCE, cDCE and VC held in the voids and adsorbed to the walls of higher transmissive fractures. During the past 5 years, the masses of CVOC removed are likely from voids and walls of low transmissive fractures and from deeper within the rock matrix. Continuing P\&T activities will maintain the cone of depression to prevent movement of contaminated groundwater to surrounding residential communities and to surface-water ecological supplies, but lesser amounts of $\mathrm{CVOC}$ will be removed each month.

\section{References Cited}

EA Engineering, Science, and Technology, Inc.,1995, Site 1 Interim action well monitoring at Naval Air Warfare Center, Trenton, New Jersey, Report \#3 (August 11, 1995): Hunt Valley, MD EA Engineering, Science, and Technology, Inc., $120 \mathrm{p}$.

ECOR Solutions, Inc., September 2003 to November 2003, Groundwater pump \& treat system, monthly report September 2003, NAWC Trenton, NJ: Ewing, NJ, ECOR Solutions, Inc., Individual reports of about 20 pages produced monthly from September to November 2003.

ECOR Solutions, Inc., December 2003 to December 2009, Groundwater treatment plant report, Trenton, NJ: Ewing NJ, Individual reports of 15-20 pages produced monthly from December 2003 to December 2009.

Foster Wheeler Environmental Corporation, November 7, 1995, Safety, health, and emergency response plan, Naval Air Warfare center, Trenton, NJ; Pump-and-treat remediation of groundwater contaminated with DCE, TCE and VC: Houston, TX, 200 p.

Foster Wheeler Environmental Corporation, February 1996 to December 1998, Groundwater treatment facility operations and maintenance monthly report, February 1996, Naval Air Warfare Center, Trenton, NJ: Ewing, NJ, Foster Wheeler Environmental Corporation, 5 p. Individual reports of 3-4 pages produced monthly from February 1996 to December 1998.

Foster Wheeler Environmental Corporation, February 1996, Groundwater treatment facility operations and maintenance monthly report, Naval Air Warfare Center, Trenton NJ: Ewing, NJ, Foster Wheeler Environmental Corporation. Individual reports of 4 to 6 pages produced monthly from February 1996 to December 1998.
Foster Wheeler Environmental Corporation, February 1996, Groundwater treatment facility operations and maintenance monthly report, Naval Air Warfare Center, Trenton NJ: Ewing, NJ, Foster Wheeler Environmental Corporation. Individual reports of 15 to 20 pages produced monthly from January 1999 to August 2003.

H\&S Environmental, Incorporated, March 2010 to December 2010, Groundwater treatment plant report, Trenton, NJ: Ewing NJ. Individual reports of 15-20 pages produced monthly from December March 2010 to December 2010.

Lacombe, P.J., 2007, Estimating volume and removal of source TCE by pump and treat, ground water discharge, and bioremediation, Naval Air Warfare Center, West Trenton, NJ: National Groundwater Association Meeting, Portland, Maine, 2007, Poster.

Rogers, Golden \& Halpern, 1986, Initial Assessment Study Naval Air propulsion Center, Trenton, New Jersey: Philadelphia, PA, $122 \mathrm{p}$.

U.S. Environmental Protection Agency, 1996, Pump-and-treat ground-water remediation, A guide for decision makers and practitioners: EPA/625/R-95/005, 90 p. 
Table 1. Reported monthly data and cumulative mass of trichloroethylene (TCE), cis-dichloroethylene (cDCE), vinyl chloride (VC), and original TCE removed based on volume of influent and concentrations of CVOCs in influent to the Pump-and-Treat plant (Method 1), Naval Air Warfare Center, West Trenton, NJ, February 1996 through December 2010.

[CVOC, chlorinated volatile organic compound; TCE, trichloroethylene, cDCE, cis-dichloroethylene; VC, vinyl chloride; tDCE, trans-dichloroethylene; $\mathrm{gal} / \mathrm{mon}$, gallons per month; $\mu \mathrm{g} / \mathrm{L}$, micrograms per liter; $\mathrm{lb} /$ mon pounds per month; lb pounds; moles/mon, moles per month, Bold, published values; blue cells, data estimated from a published graph; orange cells, data calculated from published data; purple cells, data calculated from reported mass removed; --, no data; *, estimated data; purple numbers March-April 1998 combined report]

\begin{tabular}{|c|c|c|c|c|c|c|c|c|c|c|c|c|c|c|}
\hline Date & Days & \multicolumn{2}{|c|}{ Influent volume } & \multicolumn{4}{|c|}{$\begin{array}{l}\text { CVOC concentrations } \\
\text { in influent }\end{array}$} & \multicolumn{4}{|c|}{$\begin{array}{c}\text { Monthly CVOC } \\
\text { mass removed } \\
\text { from influent }\end{array}$} & \multicolumn{3}{|c|}{$\begin{array}{c}\text { Cumulative CVOC } \\
\text { mass removed } \\
\text { from influent }\end{array}$} \\
\hline Jan-1996 & 31 & not started & -- & -- & -- & -- & -- & -- & -- & -- & -- & & & \\
\hline Feb-1996 & 28 & 208,413 & 208,413 & 3,000 & 15,000 & 2,500 & $15^{*}$ & 5.2 & 26.1 & 4.3 & 0.0 & 5 & 26 & 4 \\
\hline Mar-1996 & 31 & 416,600 & 625,013 & 6,000 & 25,000 & 4,000 & $15^{*}$ & 20.9 & 86.9 & 13.9 & 0.1 & 26 & 113 & 18 \\
\hline Apr-1996 & 30 & 596,400 & $1,221,413$ & 18,000 & 35,000 & 8,000 & $15^{*}$ & 89.6 & 174.2 & 39.8 & 0.1 & 116 & 287 & 58 \\
\hline Sep-1996 & 30 & 588,700 & $3,801,103$ & 16,000 & 40,000 & 5,000 & $15^{*}$ & 78.6 & 196.5 & 24.6 & 0.1 & 440 & 997 & 170 \\
\hline Oct-1996 & 31 & 468,200 & $4,269,303$ & 18,000 & 42,000 & 6,000 & $15^{*}$ & 70.3 & 164.1 & 23.4 & 0.1 & 510 & 1,161 & 193 \\
\hline Nov-1996 & 30 & 596,900 & $4,866,203$ & 25,000 & 62,000 & 8,000 & $15^{*}$ & 124.5 & 308.8 & 39.9 & 0.1 & 635 & 1,470 & 233 \\
\hline Dec-1996 & 31 & 202,500 & $5,068,703$ & 25,000 & 60,000 & 10,000 & $15^{*}$ & 42.2 & 101.4 & 16.9 & 0.0 & 677 & 1,572 & 250 \\
\hline Jan-1997 & 31 & 400,000 & $5,468,703$ & 20,000 & 52,000 & 7,500 & $15^{*}$ & 66.8 & 173.6 & 25.0 & 0.1 & 744 & 1,745 & 275 \\
\hline Feb-1997 & 28 & 468,600 & $5,937,303$ & 18,000 & 50,000 & 7,500 & $15^{*}$ & 70.4 & 195.5 & 29.3 & 0.1 & 814 & 1,941 & 304 \\
\hline Mar-1997 & 31 & 407,100 & $6,344,403$ & 18,000 & 55,000 & 7,500 & $15^{*}$ & 61.2 & 186.9 & 25.5 & 0.1 & 875 & 2,128 & 330 \\
\hline Apr-1997 & 30 & 590,200 & $6,934,603$ & 18,000 & 55,000 & 7,500 & $15^{*}$ & 88.7 & 270.9 & 36.9 & 0.1 & 964 & 2,399 & 367 \\
\hline May-1997 & 31 & 661,657 & $7,596,260$ & 15,000 & 55,000 & 6,000 & $15^{*}$ & 82.8 & 303.7 & 33.1 & 0.1 & 1,047 & 2,702 & 400 \\
\hline Jan-1998 & 31 & 362,000 & $11,141,660$ & 9,000 & 30,000 & 5,000 & $15^{*}$ & 27.2 & 90.6 & 15.1 & 0.0 & 1,280 & 3,496 & 528 \\
\hline Feb-1998 & 28 & 373,700 & $11,515,360$ & 6,000 & 15,500 & 4,000 & $15^{*}$ & 18.7 & 48.3 & 12.5 & 0.0 & 1,298 & 3,545 & 541 \\
\hline Mar-1998 & 31 & 474,344 & $11,989,704$ & 5,000 & 18,000 & 4,000 & $15^{*}$ & 19.8 & 71.3 & 15.8 & 0.1 & 1,318 & 3,616 & 556 \\
\hline Apr-1998 & 30 & $1,350,056$ & $13,339,760$ & 5,000 & 18,000 & 4,000 & $15^{*}$ & 56.3 & 202.8 & 45.1 & 0.2 & 1,375 & 3,819 & 601 \\
\hline May-1998 & 31 & $1,295,600$ & $14,635,360$ & 4,000 & 12,500 & 4,000 & $15^{*}$ & 43.2 & 135.2 & 43.2 & 0.2 & 1,418 & 3,954 & 645 \\
\hline Jun-1998 & 30 & $1,421,700$ & $16,057,060$ & 3,500 & 11,500 & 2,500 & $15^{*}$ & 41.5 & 136.4 & 29.7 & 0.2 & 1,459 & 4,091 & 674 \\
\hline Jul-1998 & 31 & no report & $16,057,060$ & -- & -- & -- & -- & & & & & 1,459 & 4,091 & 674 \\
\hline Aug-1998 & 31 & $1,101,700$ & $17,158,760$ & 1,200 & 2,000 & 500 & $10^{*}$ & 11.0 & 18.4 & 4.6 & 0.1 & 1,470 & 4,109 & 679 \\
\hline Sep-1998 & 30 & 717,700 & $17,876,460$ & 2,500 & 5,500 & 2,500 & $10^{*}$ & 15.0 & 32.9 & 15.0 & 0.1 & 1,485 & 4,142 & 694 \\
\hline Oct-1998 & 31 & $1,353,100$ & $19,229,560$ & 3,500 & 10,000 & 2,200 & $10^{*}$ & 39.5 & 112.9 & 24.8 & 0.2 & 1,525 & 4,255 & 719 \\
\hline Nov-1998 & 30 & $1,202,800$ & $20,432,360$ & 5,000 & 12,000 & 2,500 & $10^{*}$ & 50.2 & 120.5 & 25.1 & 0.2 & 1,575 & 4,376 & 744 \\
\hline Dec-1998 & 31 & $1,520,500$ & $21,952,860$ & 4,000 & 9,500 & 2,000 & $10^{*}$ & 50.8 & 120.5 & 25.4 & 0.2 & 1,626 & 4,497 & 769 \\
\hline Jan-1999 & 31 & $1,660,200$ & $23,613,060$ & 4,014 & 7,063 & 2,157 & $10^{*}$ & 55.6 & 97.9 & 29.9 & 0.2 & 1,681 & 4,595 & 799 \\
\hline
\end{tabular}


Table 1. Reported monthly data and cumulative mass of trichloroethylene (TCE), cis-dichloroethylene (CDCE), vinyl chloride (VC), and original TCE removed based on volume of influent and concentrations of CVOCs in influent to the Pump-and-Treat plant (Method 1), Naval Air Warfare Center, West Trenton, NJ, February 1996 through December 2010.—Continued

[CVOC, chlorinated volatile organic compound; TCE, trichloroethylene, cDCE, cis-dichloroethylene; VC, vinyl chloride; tDCE, trans-dichloroethylene; gal/mon, gallons per month; $\mu \mathrm{g} / \mathrm{L}$, micrograms per liter; lb/mon pounds per month; lb pounds; moles/mon, moles per month, Bold, published values; blue cells, data estimated from a published graph; orange cells, data calculated from published data; purple cells, data calculated from reported mass removed; --, no data; *, estimated data; purple numbers March-April 1998 combined report]

\begin{tabular}{|c|c|c|c|c|c|c|c|c|c|c|c|c|c|c|}
\hline Date & Days & \multicolumn{2}{|c|}{ Influent volume } & \multicolumn{4}{|c|}{$\begin{array}{l}\text { CVOC concentrations } \\
\text { in influent }\end{array}$} & \multicolumn{4}{|c|}{$\begin{array}{l}\text { Monthly CVOC } \\
\text { mass removed } \\
\text { from influent }\end{array}$} & \multicolumn{3}{|c|}{$\begin{array}{c}\text { Cumulative CVOC } \\
\text { mass removed } \\
\text { from influent }\end{array}$} \\
\hline Feb-1999 & 28 & $1,276,400$ & $24,889,460$ & 4,460 & 10,269 & 2,420 & $10^{*}$ & 47.5 & 109.4 & 25.8 & 0.2 & 1,729 & 4,704 & 825 \\
\hline Mar-1999 & 31 & 231,400 & $25,120,860$ & 3,515 & 8,092 & 1,907 & $10^{*}$ & 7 & 16 & 4 & 0 & 1,736 & 4,720 & 829 \\
\hline Apr-1999 & $\mathbf{X 3 0}$ & 0 & $25,120,860$ & -- & -- & -- & -- & 0 & 0 & 0 & 0 & 1,736 & 4,720 & 829 \\
\hline May-1999 & 31 & $1,888,100$ & $27,008,960$ & 4,160 & 10,460 & 2,720 & 41 & 65.6 & 164.8 & 42.9 & 0.7 & 1,801 & 4,886 & 871 \\
\hline Oct-1999 & 31 & $2,354,200$ & $33,111,860$ & 4,883 & 7,016 & 1,917 & 39 & 95.9 & 137.9 & 37.7 & 0.8 & 2,015 & 5,224 & 962 \\
\hline Nov-1999 & 30 & $1,700,300$ & $34,812,160$ & 4,900 & 6,625 & 1,400 & 40 & 69.5 & 94.0 & 19.9 & 0.6 & 2,085 & 5,319 & 982 \\
\hline Dec-1999 & 31 & $2,304,100$ & $37,116,260$ & 4,986 & 6,657 & 1,550 & 42 & 95.9 & 128.0 & 29.8 & 0.8 & 2,181 & 5,447 & 1,012 \\
\hline Jan-2000 & 31 & $1,764,300$ & $38,880,560$ & 4,800 & 6,400 & 853 & 37 & 70.7 & 94.2 & 12.6 & 0.5 & 2,251 & 5,542 & 1,025 \\
\hline Feb-2000 & 29 & $1,762,800$ & $40,643,360$ & 4,525 & 6,212 & 1,525 & 37 & 66.6 & 91.4 & 22.4 & 0.6 & 2,318 & 5,634 & 1,047 \\
\hline Mar-2000 & 31 & $1,858,300$ & $42,501,660$ & 5,060 & 6,600 & 1,680 & 37 & 78.5 & 102.4 & 26.1 & 0.6 & 2,396 & 5,737 & 1,073 \\
\hline Apr-2000 & 30 & $2,014,800$ & $44,516,460$ & 5,225 & 6,450 & 1,525 & 39 & 87.9 & 108.5 & 25.6 & 0.7 & 2,484 & 5,846 & 1,099 \\
\hline May-2000 & 31 & $1,746,300$ & $46,262,760$ & 5,000 & 6,375 & 1,425 & 36 & 72.9 & 92.9 & 20.8 & 0.5 & 2,557 & 5,940 & 1,119 \\
\hline Jun-2000 & 30 & $1,975,800$ & $48,238,560$ & 4,600 & 5,817 & 1,072 & 28 & 75.9 & 95.9 & 17.7 & 0.5 & 2,633 & 6,036 & 1,137 \\
\hline Feb-2001 & 28 & $1,792,200$ & $62,169,360$ & 4,900 & 7,400 & 1,700 & 43 & 73.3 & 110.7 & 25.4 & 0.6 & 3,078 & 6,709 & 1,321 \\
\hline Mar-2001 & 31 & $2,198,200$ & $64,367,560$ & 4,900 & 7,400 & 1,700 & 43 & 89.9 & 135.8 & 31.2 & 0.8 & 3,168 & 6,845 & 1,352 \\
\hline Apr-2001 & 30 & $1,889,100$ & $66,256,660$ & 4,900 & 7,400 & 1,700 & 43 & 77.3 & 116.7 & 26.8 & 0.7 & 3,245 & 6,963 & 1,379 \\
\hline May-2001 & 31 & $1,752,400$ & $68,009,060$ & 4,900 & 7,400 & 1,700 & 43 & 71.7 & 108.2 & 24.9 & 0.6 & 3,317 & 7,072 & 1,404 \\
\hline Jun-2001 & 30 & $2,061,100$ & $70,070,160$ & 4,300 & 6,500 & 2,700 & 43 & 74.0 & 111.8 & 46.4 & 0.7 & 3,391 & 7,184 & 1,451 \\
\hline Jul-2001 & 31 & $2,072,300$ & $72,142,460$ & 4,950 & 6,250 & 2,000 & 49 & 85.6 & 108.1 & 34.6 & 0.9 & 3,476 & 7,293 & 1,485 \\
\hline Aug-2001 & 31 & $1,747,000$ & $73,889,460$ & 4,900 & 7,400 & 1,700 & 43 & 71.4 & 107.9 & 24.8 & 0.6 & 3,548 & 7,402 & 1,510 \\
\hline Sep-2001 & 30 & $1,286,000$ & $75,175,460$ & 3,900 & 1,000 & 2,100 & 59 & 41.9 & 10.7 & 22.5 & 0.6 & 3,590 & 7,413 & 1,532 \\
\hline Oct-2001 & 31 & $2,256,700$ & $77,432,160$ & 2,900 & 8,250 & 1,600 & 32 & 54.6 & 155.4 & 30.1 & 0.6 & 3,644 & 7,569 & 1,563 \\
\hline Nov-2001 & 30 & $1,922,500$ & $79,354,660$ & 1,500 & 2,900 & 600 & 6 & 24.1 & 46.5 & 9.6 & 0.1 & 3,668 & 7,616 & 1,572 \\
\hline Dec-2001 & 31 & $1,938,500$ & $81,293,160$ & 2,357 & 6,471 & 1,943 & 11 & 38.1 & 104.7 & 31.4 & 0.2 & 3,706 & 7,720 & 1,604 \\
\hline Jan-2002 & 31 & $2,015,000$ & $83,308,160$ & 2,229 & 5,529 & 1,957 & 9 & 37.5 & 93.0 & 32.9 & 0.2 & 3,744 & 7,814 & 1,637 \\
\hline Feb-2002 & 28 & $1,658,600$ & $84,966,760$ & 2,233 & 4,933 & 1,583 & 9 & 30.9 & 68.3 & 21.9 & 0.1 & 3,775 & 7,882 & 1,658 \\
\hline
\end{tabular}


Table 1. Reported monthly data and cumulative mass of trichloroethylene (TCE), cis-dichloroethylene (cDCE), vinyl chloride (VC), and original TCE removed based on volume of influent and concentrations of CVOCs in influent to the Pump-and-Treat plant (Method 1), Naval Air Warfare Center, West Trenton, NJ, February 1996 through December 2010.—Continued

[CVOC, chlorinated volatile organic compound; TCE, trichloroethylene, cDCE, cis-dichloroethylene; VC, vinyl chloride; tDCE, trans-dichloroethylene; $\mathrm{gal} / \mathrm{mon}$, gallons per month; $\mu \mathrm{g} / \mathrm{L}$, micrograms per liter; $\mathrm{lb} /$ mon pounds per month; lb pounds; moles/mon, moles per month, Bold, published values; blue cells, data estimated from a published graph; orange cells, data calculated from published data; purple cells, data calculated from reported mass removed; --, no data; *, estimated data; purple numbers March-April 1998 combined report]

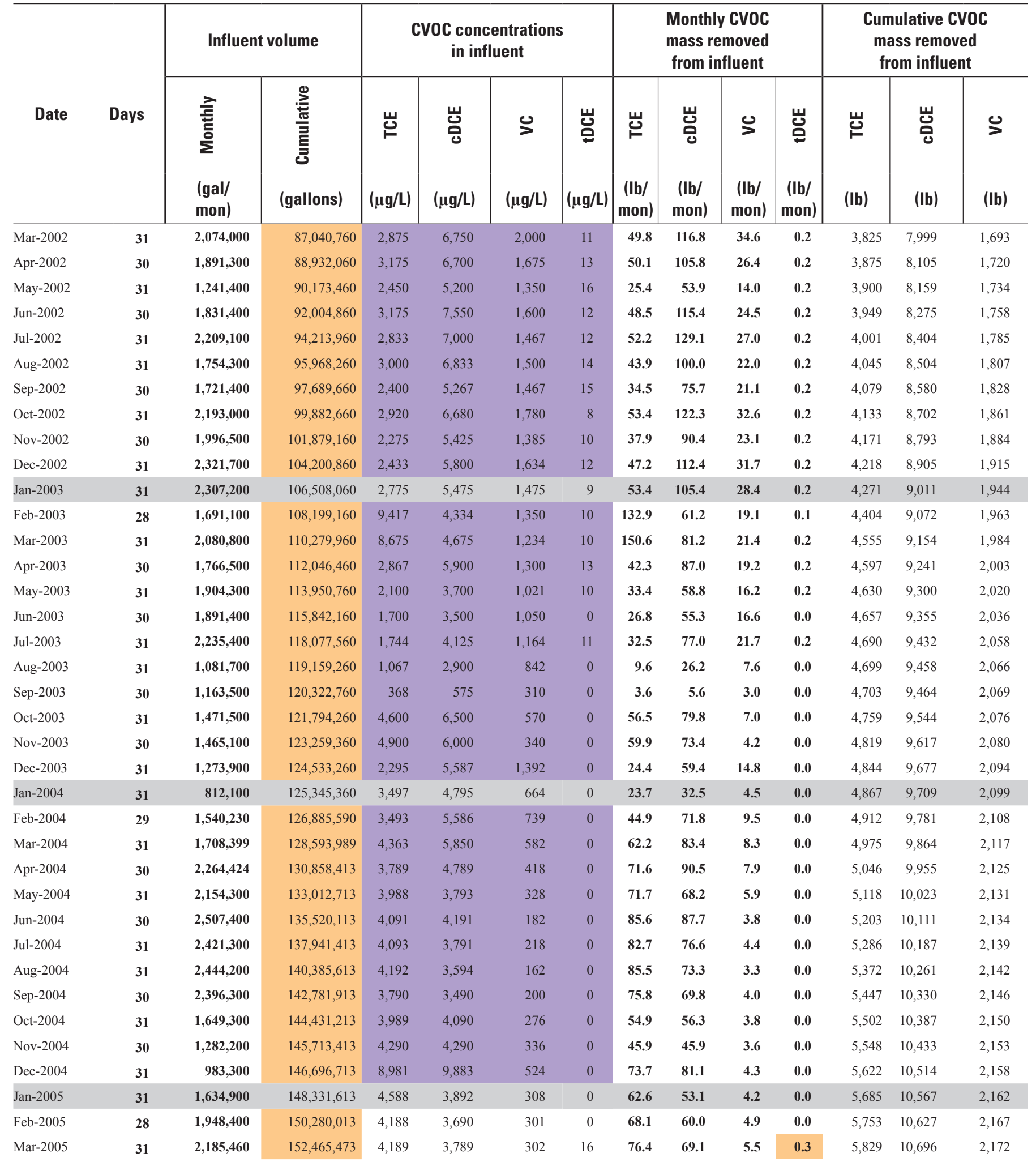


Table 1. Reported monthly data and cumulative mass of trichloroethylene (TCE), cis-dichloroethylene (CDCE), vinyl chloride (VC), and original TCE removed based on volume of influent and concentrations of CVOCs in influent to the Pump-and-Treat plant (Method 1), Naval Air Warfare Center, West Trenton, NJ, February 1996 through December 2010.—Continued

[CVOC, chlorinated volatile organic compound; TCE, trichloroethylene, cDCE, cis-dichloroethylene; VC, vinyl chloride; tDCE, trans-dichloroethylene; gal/mon, gallons per month; $\mu \mathrm{g} / \mathrm{L}$, micrograms per liter; lb/mon pounds per month; lb pounds; moles/mon, moles per month, Bold, published values; blue cells, data estimated from a published graph; orange cells, data calculated from published data; purple cells, data calculated from reported mass removed; --, no data; *, estimated data; purple numbers March-April 1998 combined report]

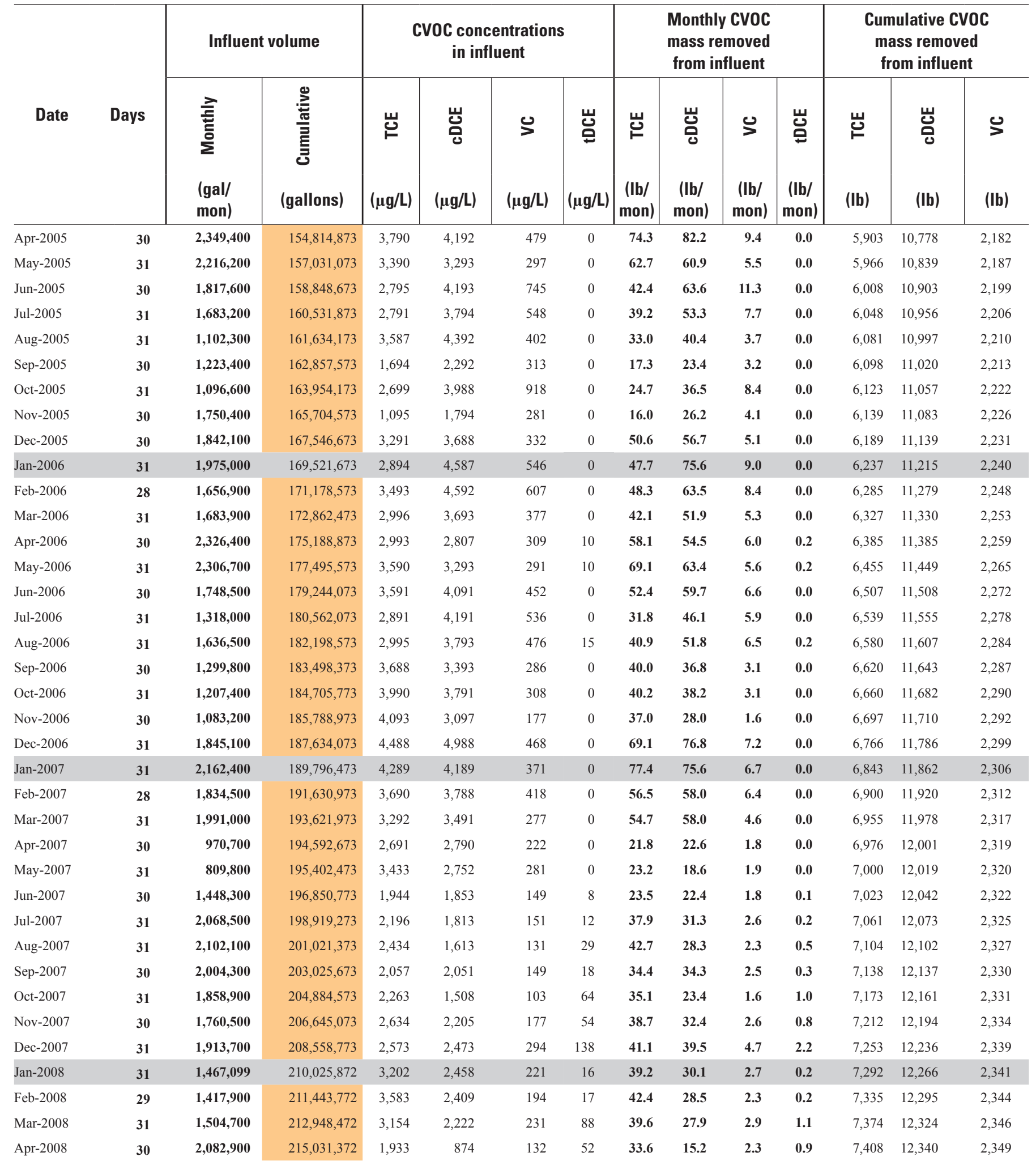


Table 1. Reported monthly data and cumulative mass of trichloroethylene (TCE), cis-dichloroethylene (cDCE), vinyl chloride (VC), and original TCE removed based on volume of influent and concentrations of CVOCs in influent to the Pump-and-Treat plant (Method 1), Naval Air Warfare Center, West Trenton, NJ, February 1996 through December 2010.—Continued

[CVOC, chlorinated volatile organic compound; TCE, trichloroethylene, cDCE, cis-dichloroethylene; VC, vinyl chloride; tDCE, trans-dichloroethylene; $\mathrm{gal} / \mathrm{mon}$, gallons per month; $\mu \mathrm{g} / \mathrm{L}$, micrograms per liter; $\mathrm{lb} /$ mon pounds per month; lb pounds; moles/mon, moles per month, Bold, published values; blue cells, data estimated from a published graph; orange cells, data calculated from published data; purple cells, data calculated from reported mass removed; --, no data; *, estimated data; purple numbers March-April 1998 combined report]

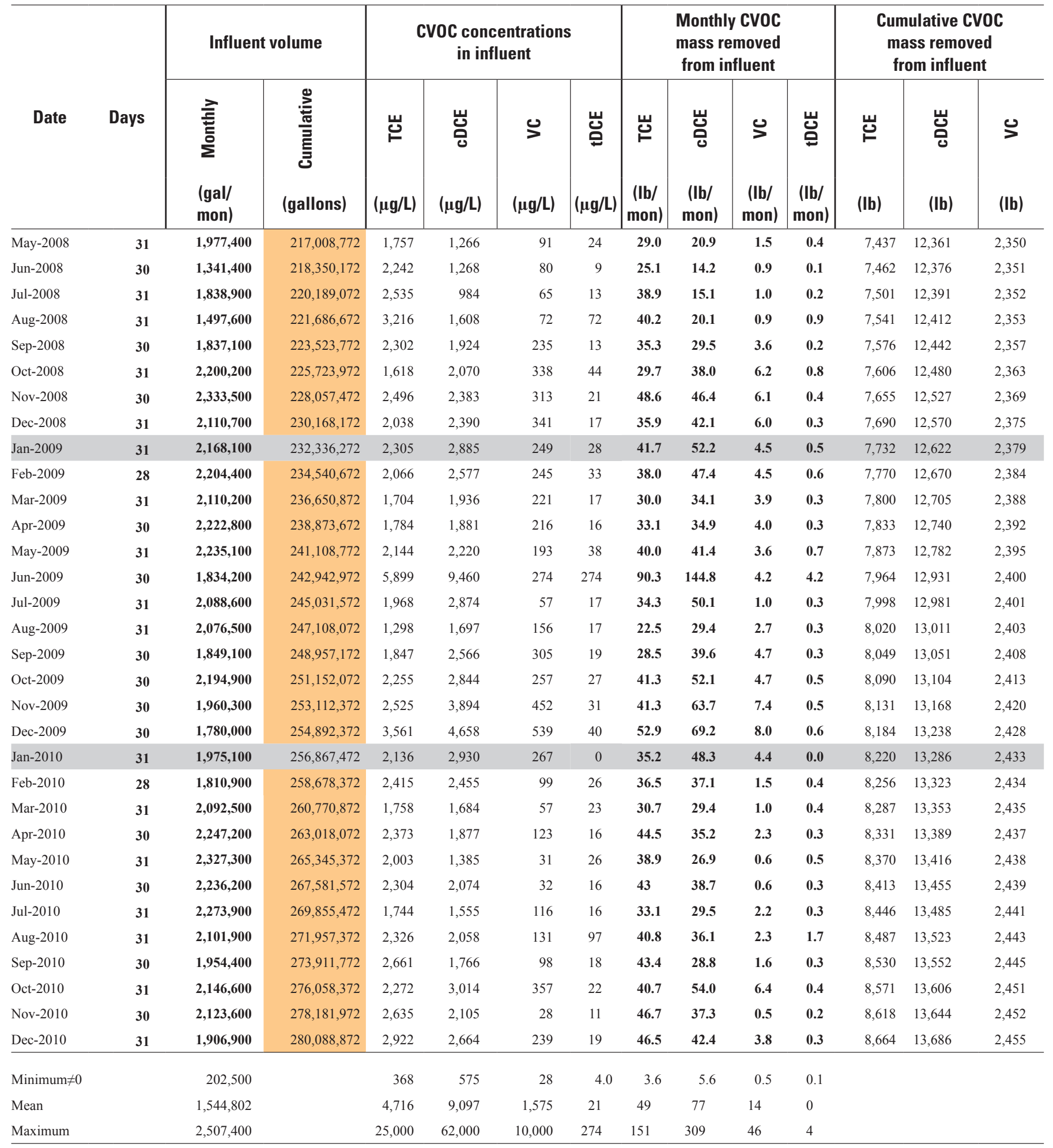


Table 1. Reported monthly data and cumulative mass of trichloroethylene (TCE), cis-dichloroethylene (CDCE), vinyl chloride (VC), and original TCE removed based on volume of influent and concentrations of CVOCs in influent to the Pump-and-Treat plant (Method 1), Naval Air Warfare Center, West Trenton, NJ, February 1996 through December 2010.—Continued

[CVOC, chlorinated volatile organic compound; TCE, trichloroethylene, cDCE, cis-dichloroethylene; VC, vinyl chloride; tDCE, trans-dichloroethylene; gal/mon, gallons per month; $\mu \mathrm{g} / \mathrm{L}$, micrograms per liter; lb/mon pounds per month; lb pounds; moles/mon, moles per month, Bold, published values; blue cells, data estimated from a published graph; orange cells, data calculated from published data; purple cells, data calculated from reported mass removed; --, no data; *, estimated data; purple numbers March-April 1998 combined report]

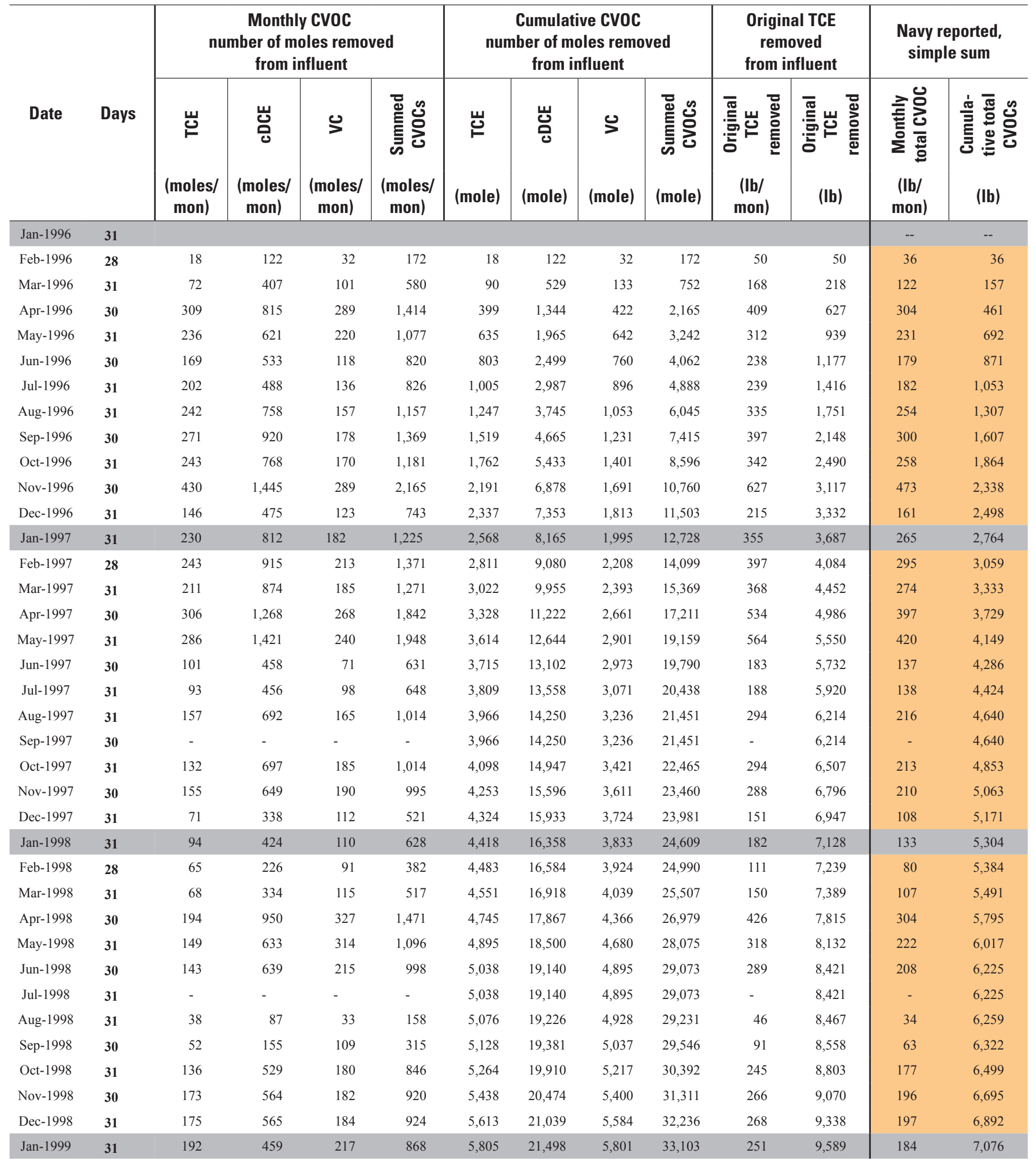


Table 1. Reported monthly data and cumulative mass of trichloroethylene (TCE), cis-dichloroethylene (cDCE), vinyl chloride (VC), and original TCE removed based on volume of influent and concentrations of CVOCs in influent to the Pump-and-Treat plant (Method 1), Naval Air Warfare Center, West Trenton, NJ, February 1996 through December 2010.—Continued

[CVOC, chlorinated volatile organic compound; TCE, trichloroethylene, cDCE, cis-dichloroethylene; VC, vinyl chloride; tDCE, trans-dichloroethylene; $\mathrm{gal} / \mathrm{mon}$, gallons per month; $\mu \mathrm{g} / \mathrm{L}$, micrograms per liter; $\mathrm{lb} /$ mon pounds per month; lb pounds; moles/mon, moles per month, Bold, published values; blue cells, data estimated from a published graph; orange cells, data calculated from published data; purple cells, data calculated from reported mass removed; --, no data; *, estimated data; purple numbers March-April 1998 combined report]

\begin{tabular}{|c|c|c|c|c|c|c|c|c|c|c|c|c|c|}
\hline Date & Days & \multicolumn{4}{|c|}{$\begin{array}{c}\text { Monthly CVOC } \\
\text { number of moles removed } \\
\text { from influent }\end{array}$} & \multicolumn{4}{|c|}{$\begin{array}{c}\text { Cumulative CVOC } \\
\text { number of moles removed } \\
\text { from influent }\end{array}$} & \multicolumn{2}{|c|}{$\begin{array}{l}\text { Original TCE } \\
\text { removed } \\
\text { from influent }\end{array}$} & \multicolumn{2}{|c|}{$\begin{array}{l}\text { Navy reported, } \\
\text { simple sum }\end{array}$} \\
\hline Feb-1999 & 28 & 164 & 513 & 187 & 864 & 5,969 & 22,010 & 5,988 & 33,967 & 250 & 9,839 & 183 & 7,258 \\
\hline Mar-1999 & 31 & 23 & 73 & 27 & 123 & 5,992 & 22,084 & 6,015 & 34,091 & 36 & 9,875 & 26 & 7,284 \\
\hline Apr-1999 & X30 & 0 & 0 & 0 & 0 & 5,992 & 22,084 & 6,015 & 34,091 & 0 & 9,875 & 0 & 7,284 \\
\hline May-1999 & 31 & 226 & 774 & 311 & 1,312 & 6,219 & 22,858 & 6,326 & 35,402 & 380 & 10,255 & 274 & 7,558 \\
\hline Jun-1999 & X30 & 0 & 0 & 0 & 0 & 6,219 & 22,858 & 6,326 & 35,402 & 0 & 10,255 & 0 & 7,558 \\
\hline Oct-1999 & 31 & 331 & 649 & 273 & 1,253 & 6,957 & 24,441 & 6,985 & 38,383 & 363 & 11,118 & 272 & 8,201 \\
\hline Nov-1999 & 30 & 240 & 443 & 144 & 827 & 7,197 & 24,883 & 7,129 & 39,209 & 239 & 11,358 & 184 & 8,385 \\
\hline Dec-1999 & 31 & 331 & 603 & 216 & 1,150 & 7,528 & 25,486 & 7,346 & 40,359 & 333 & 11,691 & 254 & 8,640 \\
\hline Jan-2000 & 31 & 244 & 443 & 91 & 779 & 7,772 & 25,929 & 7,437 & 41,138 & 226 & 11,916 & 178 & 8,818 \\
\hline Feb-2000 & 29 & 230 & 430 & 163 & 823 & 8,001 & 26,360 & 7,600 & 41,961 & 238 & 12,155 & 181 & 8,999 \\
\hline Mar-2000 & 31 & 271 & 482 & 189 & 942 & 8,272 & 26,841 & 7,789 & 42,902 & 273 & 12,427 & 207 & 9,206 \\
\hline Apr-2000 & 30 & 303 & 510 & 186 & 1,000 & 8,576 & 27,352 & 7,975 & 43,902 & 290 & 12,717 & 223 & 9,429 \\
\hline May-2000 & 31 & 252 & 437 & 151 & 840 & 8,827 & 27,789 & 8,126 & 44,741 & 243 & 12,960 & 187 & 9,616 \\
\hline Jun-2000 & 30 & 262 & 451 & 128 & 841 & 9,089 & 28,240 & 8,254 & 45,583 & 244 & 13,204 & 190 & 9,806 \\
\hline Jul-2000 & 31 & 93 & 348 & 49 & 490 & 9,182 & 28,588 & 8,303 & 46,073 & 142 & 13,346 & 108 & 9,914 \\
\hline Feb-2001 & 28 & 253 & 521 & 185 & 958 & 10,626 & 31,388 & 9,591 & 51,605 & 278 & 14,948 & 210 & 11,108 \\
\hline Mar-2001 & 31 & 310 & 639 & 226 & 1,176 & 10,936 & 32,027 & 9,817 & 52,780 & 341 & 15,289 & 258 & 11,366 \\
\hline Apr-2001 & 30 & 267 & 549 & 195 & 1,010 & 11,203 & 32,576 & 10,012 & 53,791 & 293 & 15,581 & 221 & 11,587 \\
\hline May-2001 & 31 & 247 & 509 & 180 & 937 & 11,450 & 33,085 & 10,192 & 54,728 & 271 & 15,853 & 205 & 11,792 \\
\hline Jun-2001 & 30 & 255 & 527 & 337 & 1,119 & 11,706 & 33,612 & 10,529 & 55,847 & 324 & 16,177 & 233 & 12,025 \\
\hline Jul-2001 & 31 & 296 & 510 & 251 & 1,056 & 12,001 & 34,122 & 10,780 & 56,903 & 306 & 16,483 & 229 & 12,255 \\
\hline Aug-2001 & 31 & 247 & 508 & 180 & 934 & 12,248 & 34,629 & 10,960 & 57,837 & 271 & 16,753 & 205 & 12,459 \\
\hline Sep-2001 & 30 & 145 & 53 & 164 & 361 & 12,392 & 34,682 & 11,124 & 58,199 & 105 & 16,858 & 76 & 12,535 \\
\hline Oct-2001 & 31 & 189 & 730 & 219 & 1,137 & 12,581 & 35,412 & 11,343 & 59,336 & 329 & 17,187 & 241 & 12,776 \\
\hline Nov-2001 & 30 & 83 & 218 & 70 & 371 & 12,664 & 35,630 & 11,412 & 59,707 & 108 & 17,295 & 80 & 12,856 \\
\hline Dec-2001 & 31 & 132 & 491 & 228 & 850 & 12,796 & 36,121 & 11,641 & 60,557 & 246 & 17,541 & 174 & 13,031 \\
\hline Jan-2002 & 31 & 129 & 436 & 239 & 804 & 12,925 & 36,557 & 11,879 & 61,361 & 233 & 17,774 & 164 & 13,194 \\
\hline Feb-2002 & 28 & 107 & 320 & 159 & 586 & 13,032 & 36,877 & 12,039 & 61,947 & 170 & 17,944 & 121 & 13,315 \\
\hline
\end{tabular}


Table 1. Reported monthly data and cumulative mass of trichloroethylene (TCE), cis-dichloroethylene (CDCE), vinyl chloride (VC), and original TCE removed based on volume of influent and concentrations of CVOCs in influent to the Pump-and-Treat plant (Method 1), Naval Air Warfare Center, West Trenton, NJ, February 1996 through December 2010._- Continued

[CVOC, chlorinated volatile organic compound; TCE, trichloroethylene, cDCE, cis-dichloroethylene; VC, vinyl chloride; tDCE, trans-dichloroethylene; gal/mon, gallons per month; $\mu \mathrm{g} / \mathrm{L}$, micrograms per liter; lb/mon pounds per month; lb pounds; moles/mon, moles per month, Bold, published values; blue cells, data estimated from a published graph; orange cells, data calculated from published data; purple cells, data calculated from reported mass removed; --, no data; *, estimated data; purple numbers March-April 1998 combined report]

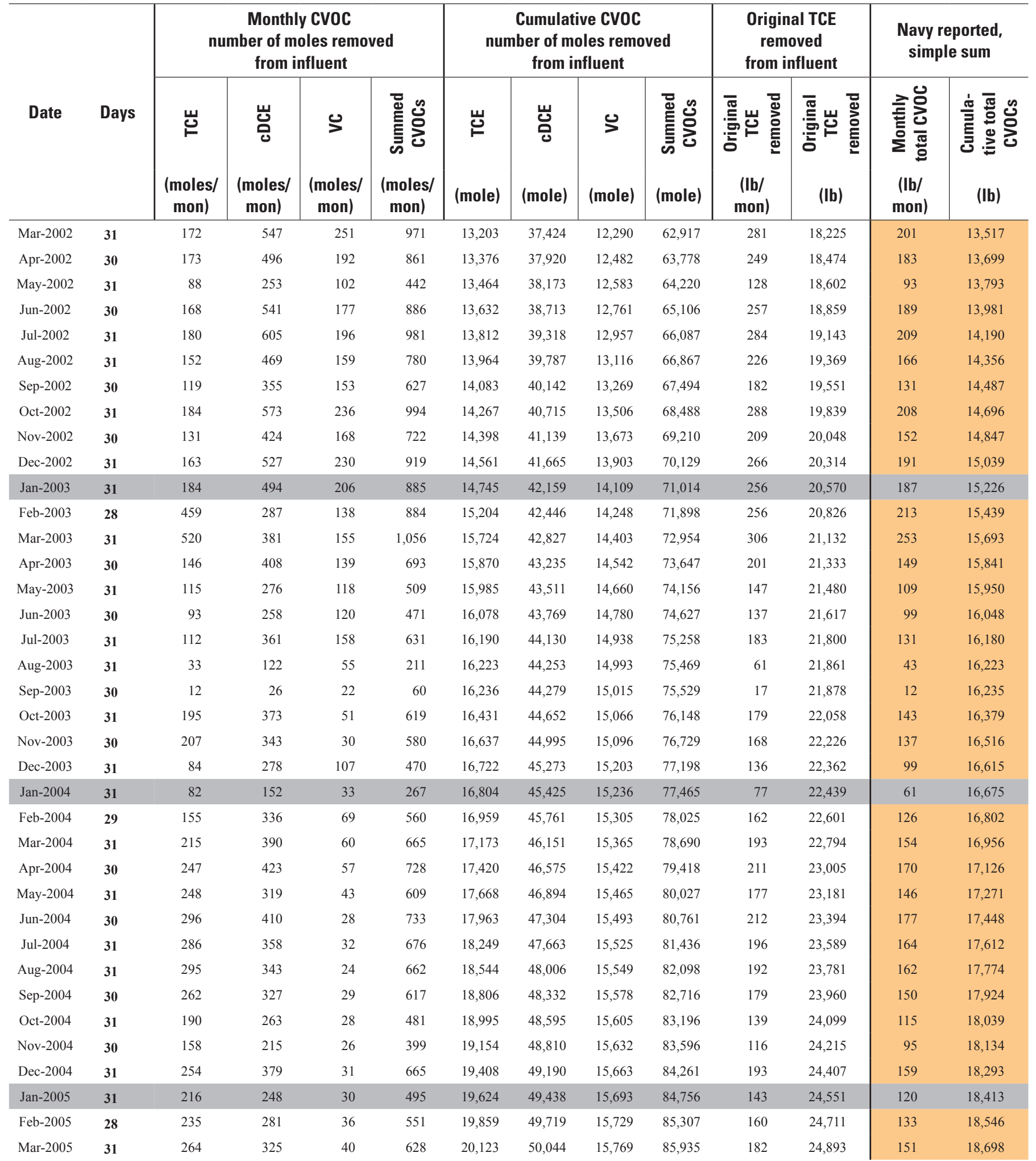


Table 1. Reported monthly data and cumulative mass of trichloroethylene (TCE), cis-dichloroethylene (cDCE), vinyl chloride (VC), and original TCE removed based on volume of influent and concentrations of CVOCs in influent to the Pump-and-Treat plant (Method 1), Naval Air Warfare Center, West Trenton, NJ, February 1996 through December 2010.—Continued

[CVOC, chlorinated volatile organic compound; TCE, trichloroethylene, cDCE, cis-dichloroethylene; VC, vinyl chloride; tDCE, trans-dichloroethylene; $\mathrm{gal} / \mathrm{mon}$, gallons per month; $\mu \mathrm{g} / \mathrm{L}$, micrograms per liter; $\mathrm{lb} /$ mon pounds per month; lb pounds; moles/mon, moles per month, Bold, published values; blue cells, data estimated from a published graph; orange cells, data calculated from published data; purple cells, data calculated from reported mass removed; --, no data; *, estimated data; purple numbers March-April 1998 combined report]

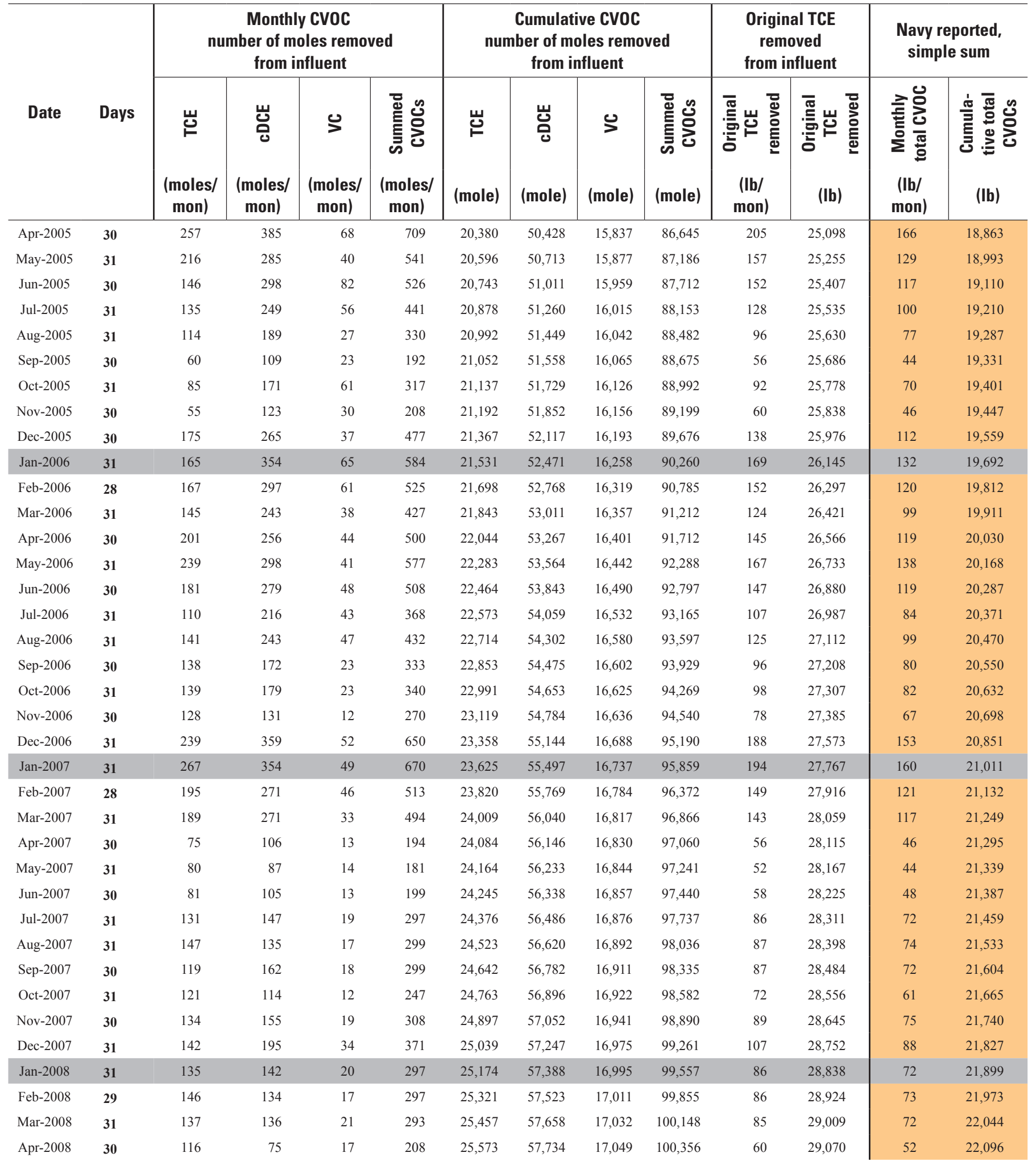


Table 1. Reported monthly data and cumulative mass of trichloroethylene (TCE), cis-dichloroethylene (CDCE), vinyl chloride (VC), and original TCE removed based on volume of influent and concentrations of CVOCs in influent to the Pump-and-Treat plant (Method 1), Naval Air Warfare Center, West Trenton, NJ, February 1996 through December 2010.—Continued

[CVOC, chlorinated volatile organic compound; TCE, trichloroethylene, cDCE, cis-dichloroethylene; VC, vinyl chloride; tDCE, trans-dichloroethylene; gal/mon, gallons per month; $\mu \mathrm{g} / \mathrm{L}$, micrograms per liter; lb/mon pounds per month; lb pounds; moles/mon, moles per month, Bold, published values; blue cells, data estimated from a published graph; orange cells, data calculated from published data; purple cells, data calculated from reported mass removed; --, no data; *, estimated data; purple numbers March-April 1998 combined report]

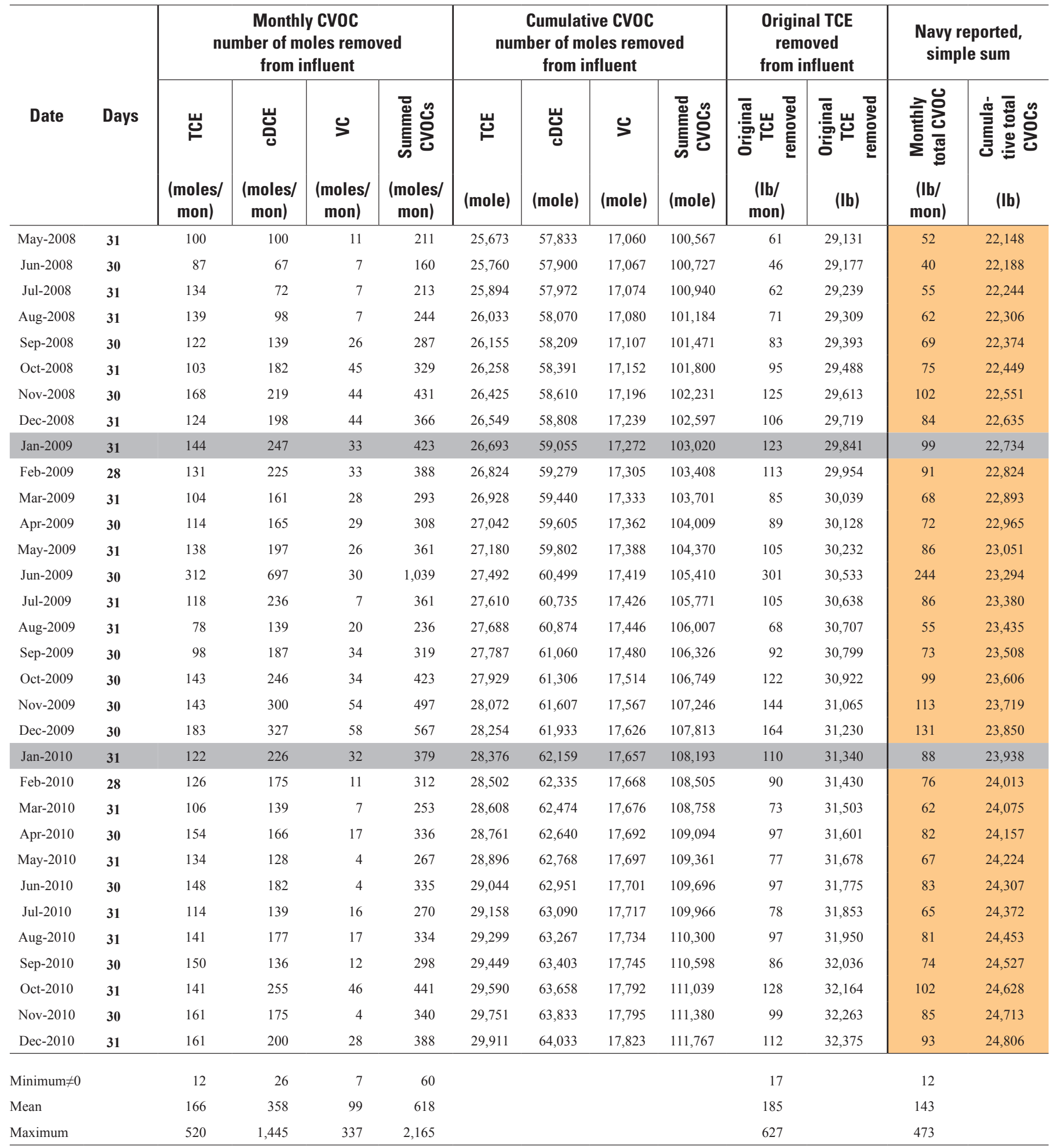


Table 5. Monthly and cumulative number of moles of trichloroethylene (TCE), cis-dichloroethylene (cDCE), vinyl chloride (VC), and original TCE removed determined by using the maximum of Methods 1 and 2, Naval Air Warfare Center, West Trenton, NJ, February 1996 through December 2010 (Method 3).

[CVOC, chlorinated volatile organic compound; TCE, trichloroethylene, $\mathrm{CDCE}$, cis-dichloroethylene; VC, vinyl chloride]

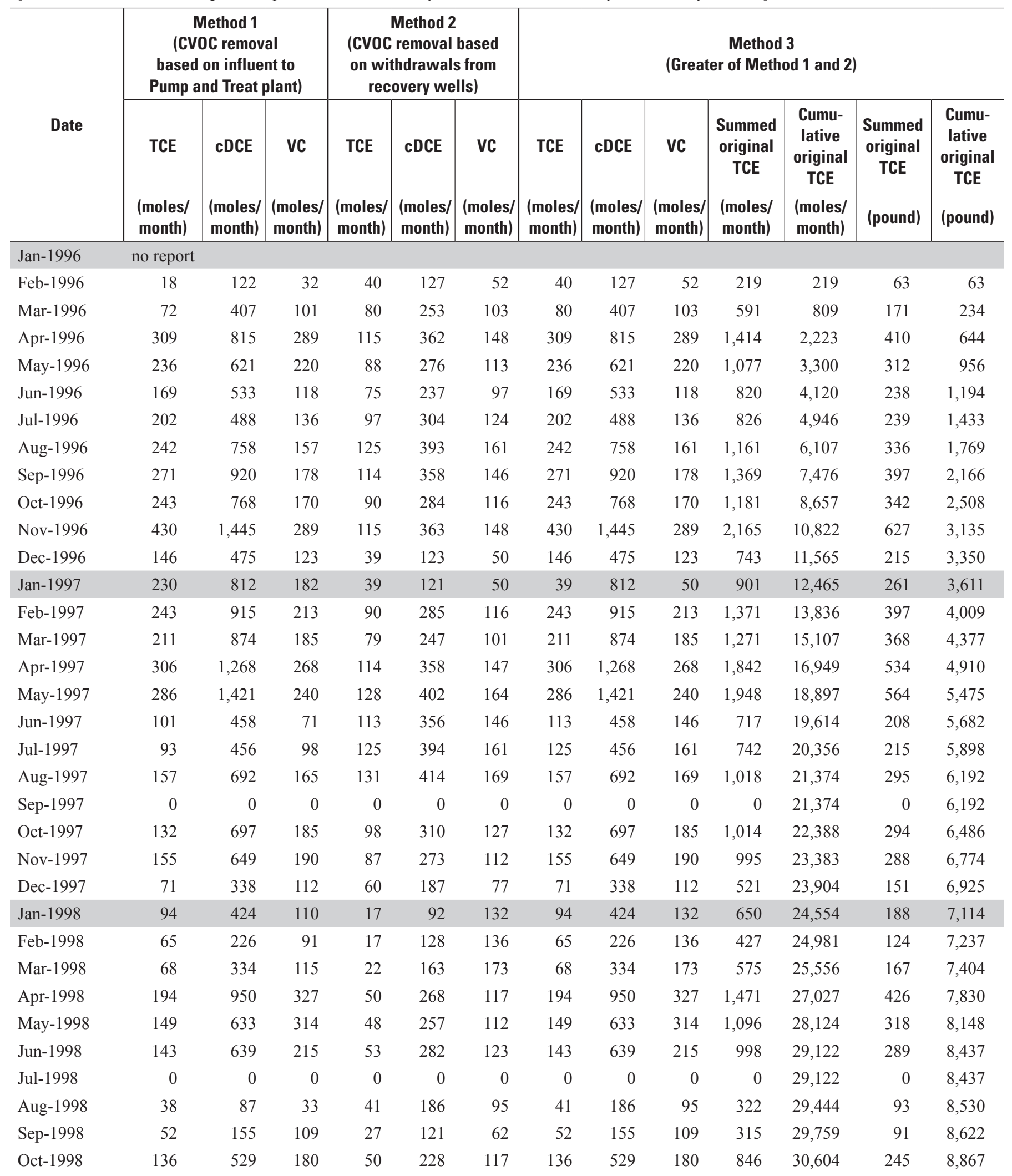


Table 5. Monthly and cumulative number of moles of trichloroethylene (TCE), cis-dichloroethylene (cDCE), vinyl chloride (VC), and original TCE removed determined by using the maximum of Methods 1 and 2, Naval Air Warfare Center, West Trenton, NJ, February 1996 through December 2010 (Method 3).-Continued

[CVOC, chlorinated volatile organic compound; TCE, trichloroethylene, cDCE, cis-dichloroethylene; VC, vinyl chloride]

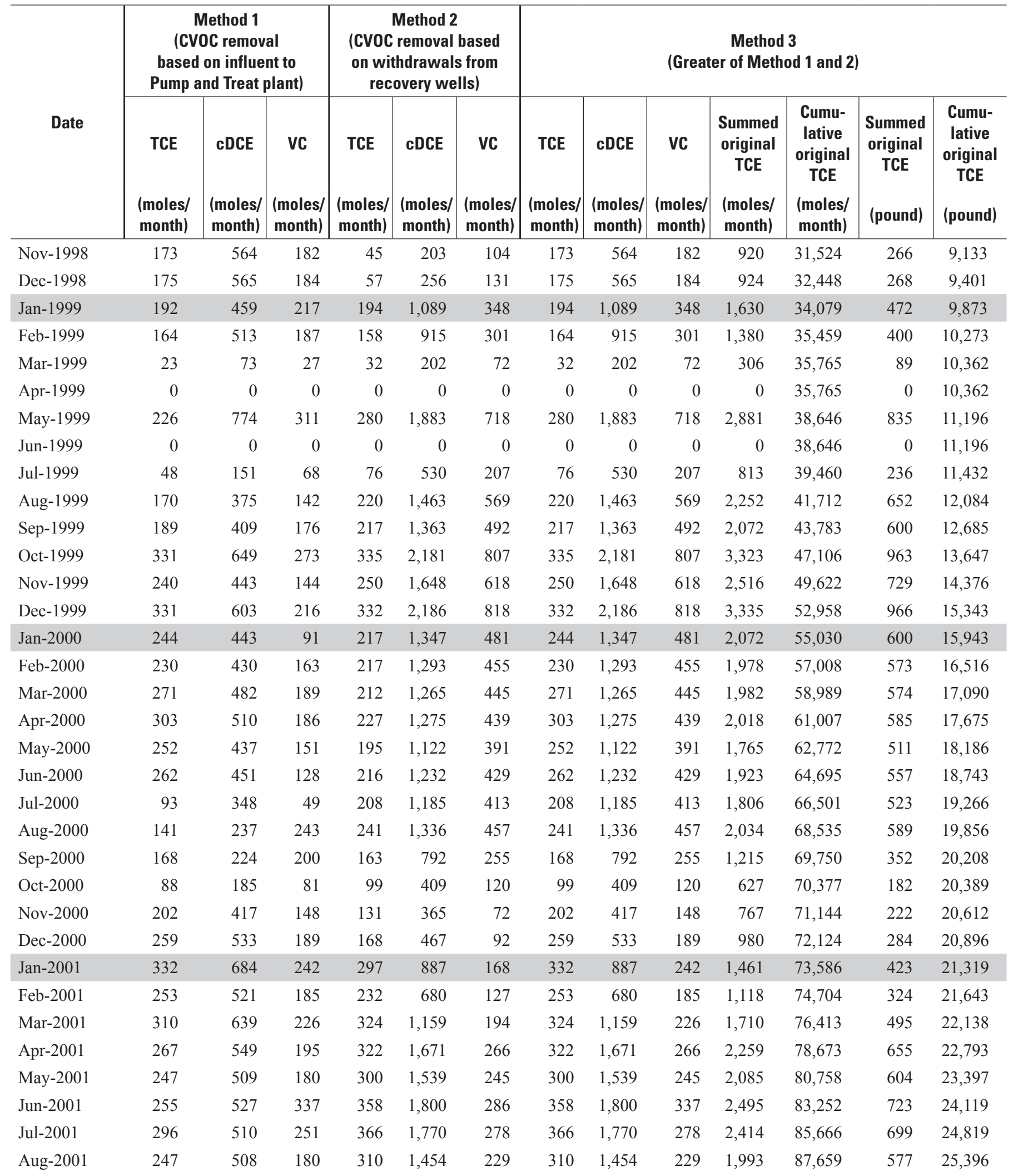


Table 5. Monthly and cumulative number of moles of trichloroethylene (TCE), cis-dichloroethylene (CDCE), vinyl chloride (VC), and original TCE removed determined by using the maximum of Methods 1 and 2, Naval Air Warfare Center, West Trenton, NJ, February 1996 through December 2010 (Method 3). - Continued

[CVOC, chlorinated volatile organic compound; TCE, trichloroethylene, cDCE, cis-dichloroethylene; VC, vinyl chloride]

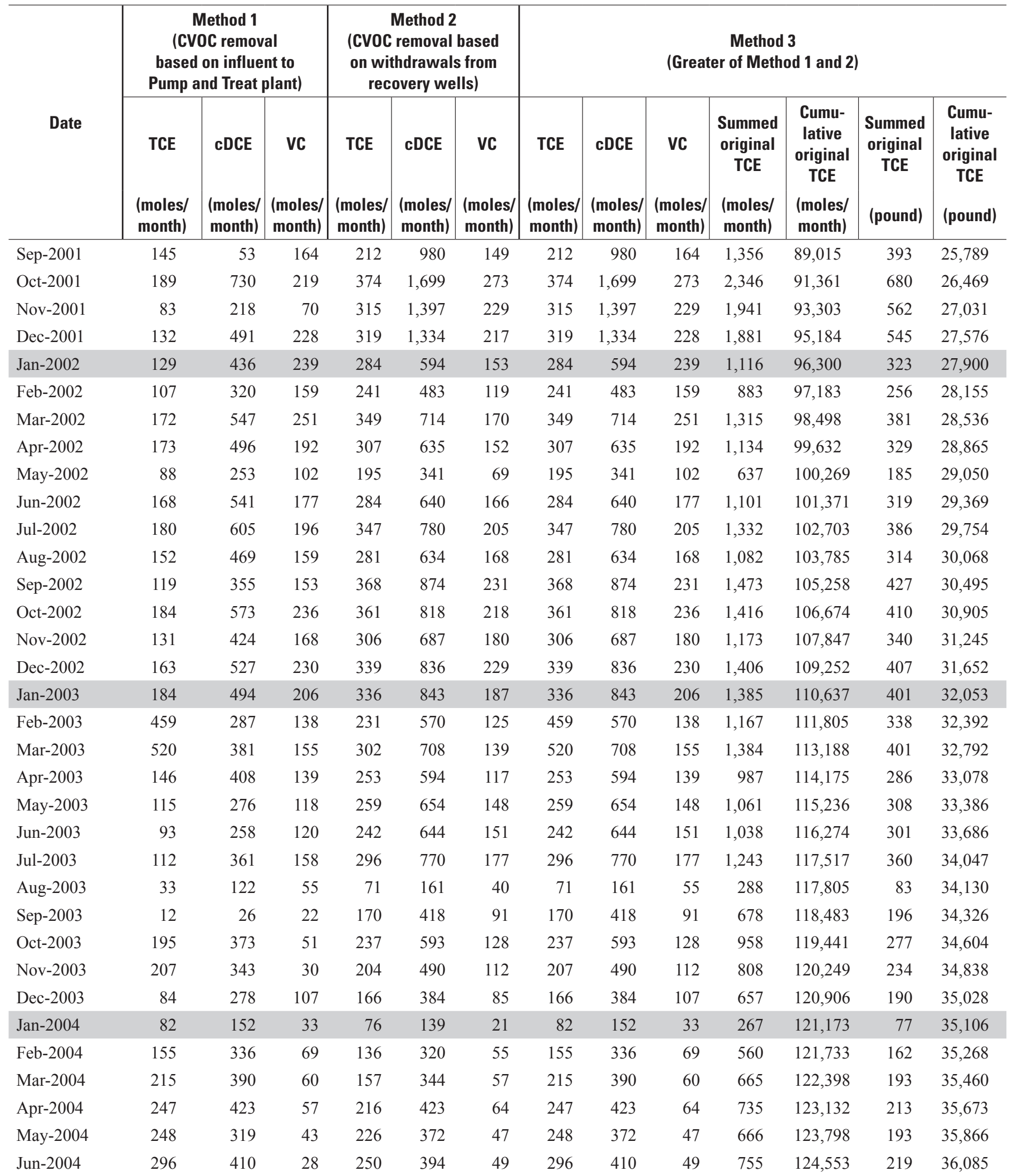


Table 5. Monthly and cumulative number of moles of trichloroethylene (TCE), cis-dichloroethylene (CDCE), vinyl chloride (VC), and original TCE removed determined by using the maximum of Methods 1 and 2, Naval Air Warfare Center, West Trenton, NJ, February 1996 through December 2010 (Method 3).-Continued

[CVOC, chlorinated volatile organic compound; TCE, trichloroethylene, cDCE, cis-dichloroethylene; VC, vinyl chloride]

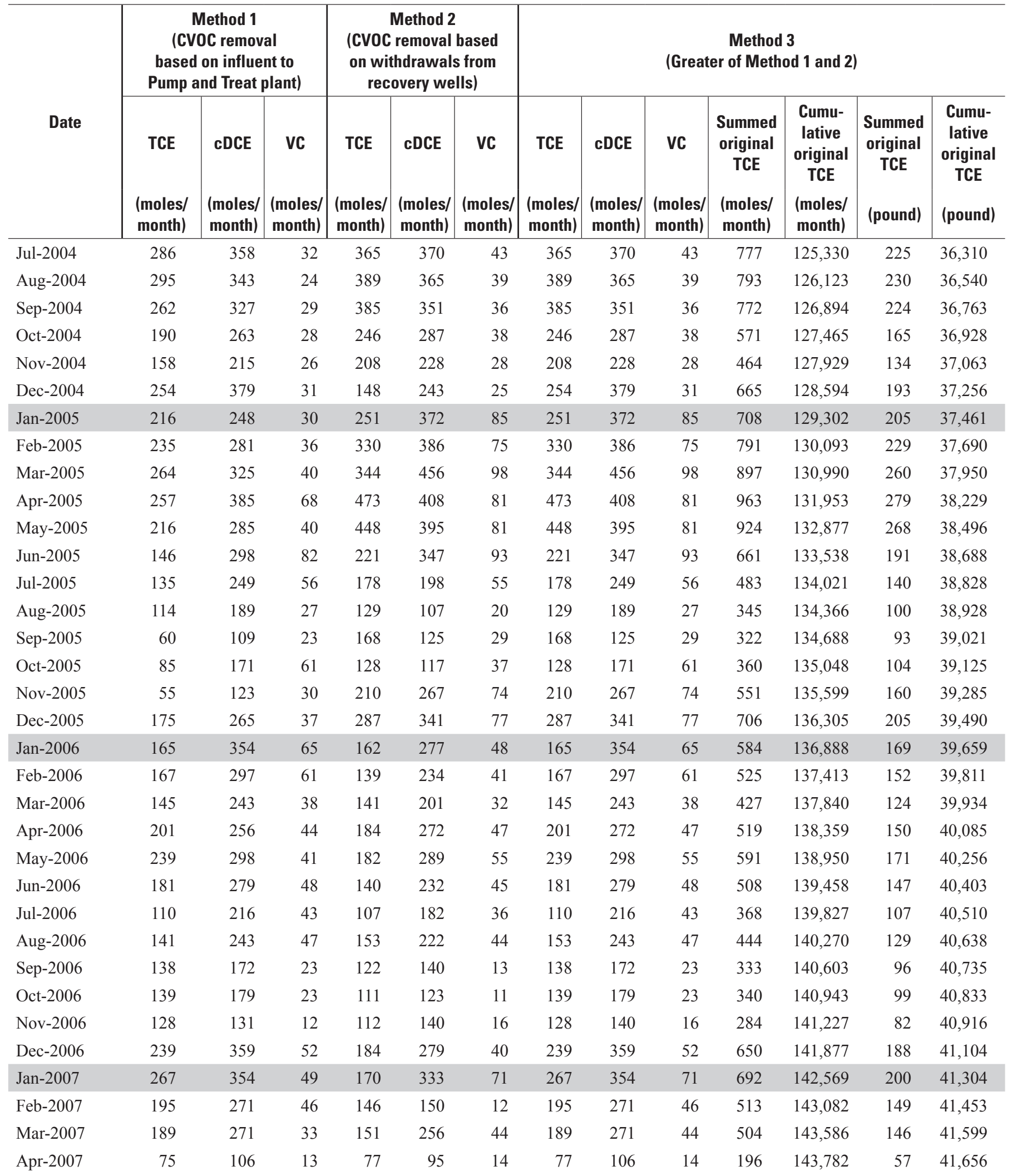


Table 5. Monthly and cumulative number of moles of trichloroethylene (TCE), cis-dichloroethylene (CDCE), vinyl chloride (VC), and original TCE removed determined by using the maximum of Methods 1 and 2, Naval Air Warfare Center, West Trenton, NJ, February 1996 through December 2010 (Method 3). - Continued

[CVOC, chlorinated volatile organic compound; TCE, trichloroethylene, cDCE, cis-dichloroethylene; VC, vinyl chloride]

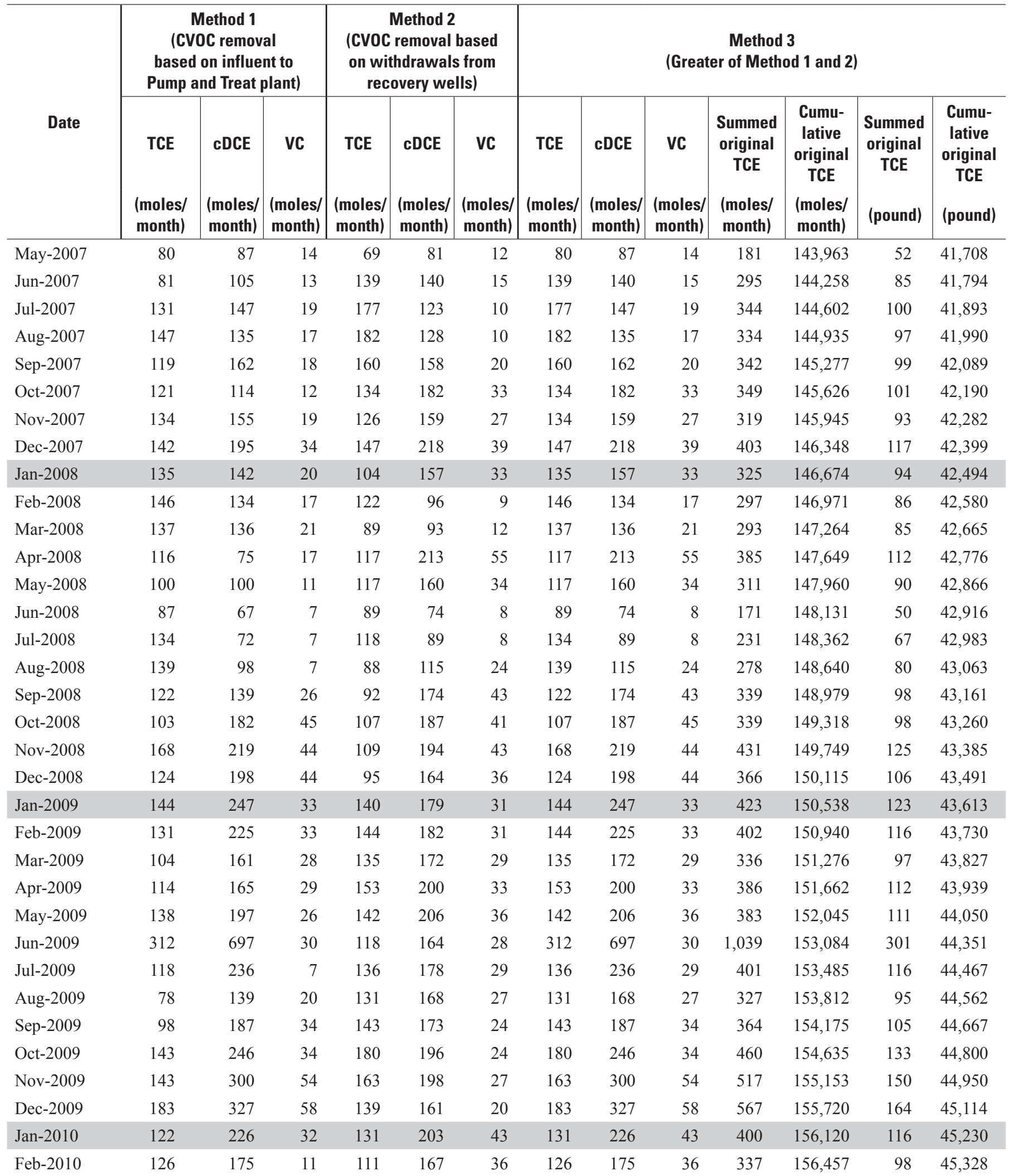


Table 5. Monthly and cumulative number of moles of trichloroethylene (TCE), cis-dichloroethylene (CDCE), vinyl chloride (VC), and original TCE removed determined by using the maximum of Methods 1 and 2, Naval Air Warfare Center, West Trenton, NJ, February 1996 through December 2010 (Method 3).-Continued

[CVOC, chlorinated volatile organic compound; TCE, trichloroethylene, cDCE, cis-dichloroethylene; VC, vinyl chloride]

\begin{tabular}{|c|c|c|c|c|c|c|c|c|c|c|c|c|c|}
\hline Date & \multicolumn{3}{|c|}{$\begin{array}{c}\text { Method } 1 \\
\text { (CVOC removal } \\
\text { based on influent to } \\
\text { Pump and Treat plant) }\end{array}$} & \multicolumn{3}{|c|}{$\begin{array}{c}\text { Method } 2 \\
\text { (CVOC removal based } \\
\text { on withdrawals from } \\
\text { recovery wells) }\end{array}$} & \multicolumn{7}{|c|}{$\begin{array}{c}\text { Method } 3 \\
\text { (Greater of Method } 1 \text { and 2) }\end{array}$} \\
\hline Mar-2010 & 106 & 139 & 7 & 142 & 137 & 13 & 142 & 139 & 13 & 294 & 156,751 & 85 & 45,413 \\
\hline Apr-2010 & 154 & 166 & 17 & 142 & 164 & 21 & 154 & 166 & 21 & 340 & 157,091 & 99 & 45,512 \\
\hline May-2010 & 134 & 128 & 4 & 151 & 169 & 19 & 151 & 169 & 19 & 339 & 157,430 & 98 & 45,610 \\
\hline Sep-2010 & 150 & 136 & 12 & 132 & 123 & 12 & 150 & 136 & 12 & 298 & 158,741 & 86 & 45,990 \\
\hline Oct-2010 & 141 & 255 & 46 & 149 & 165 & 27 & 149 & 255 & 46 & 449 & 159,190 & 130 & 46,120 \\
\hline Nov-2010 & 161 & 175 & 4 & 134 & 218 & 44 & 161 & 218 & 44 & 423 & 159,614 & 123 & 46,242 \\
\hline Dec-2010 & 161 & 200 & 28 & 121 & 196 & 40 & 161 & 200 & 40 & 400 & 160,014 & 116 & 46,358 \\
\hline Minimum $\neq 0$ & 12 & 26 & 7 & 17 & 74 & 8 & 32 & 74 & 8 & 181 & & 52 & \\
\hline Average & 166 & 358 & 99 & 173 & 465 & 124 & 203 & 550 & 141 & 894 & & 259 & \\
\hline Maximum & 520 & 1,445 & 337 & 473 & 2,186 & 818 & 520 & 2,186 & 818 & 3,335 & & 966 & \\
\hline Total moles & 29,911 & 64,033 & 17,826 & 31,012 & 83,269 & 22,180 & 36,594 & 98,369 & 25,375 & 160,338 & & & \\
\hline
\end{tabular}


For additional information, write to:

Director

U.S. Geological Survey

New Jersey Water Science Center

Mountain View Office Park

810 Bear Tavern Rd., Suite 206

West Trenton, NJ 08628

or visit our Web site at:

http://nj.usgs.gov/ 
